\title{
A HUMAN-HEALTH RISK ASSESSMENT OF DIETARY METHYLMERCURY EXPOSURE IN FORT ALBANY FIRST NATION
}

\author{
by \\ Fatima Ahmed \\ Bachelor of Applied Science \\ Ryerson University, 2015 \\ A thesis \\ presented to Ryerson University \\ in partial fulfillment of the \\ requirements for the degree of \\ Master of Applied Science \\ in the program of
}

Environmental Applied Science and Management

Toronto, Ontario, Canada, 2018

(C) FATIMA AHMED, 2018 


\section{$\underline{\text { Author's Declaration }}$}

I hereby declare that I am the sole author of this thesis. This is a true copy of the thesis, including any required final revisions, as accepted by my examiners.

I authorize Ryerson University to lend this thesis to other institutions or individuals for the purpose of scholarly research.

I further authorize Ryerson University to reproduce this thesis by photocopying or by other means, in total or in part, at the request of other institutions or individuals for the purpose of scholarly research.

I understand that my thesis may be made electronically available to the public. 


\begin{abstract}
$\underline{\text { Abstract }}$
A human-health risk assessment of dietary methylmercury exposure in Fort Albany First Nation
\end{abstract}

Master of Applied Science, 2018

Fatima Ahmed

Environmental Applied Science and Management, Ryerson University

In Northern First Nations communities, traditional diets are a primary pathway for essential nutrients and exposures to environmental contaminants. Due to long-range transport and industry pollution, Fort Albany First Nation is a community at risk of methylmercury exposures through fish. It's ability to bioaccumulate, and its neurotoxic and developmental impacts, make its presence a concern. This study assessed five fish species for methylmercury from the Albany River. All species, except for Pike, demonstrated a positive relationship with mercury concentrations increasing with length. A human health risk assessment was conducted and demonstrated twice the risk of exceeding the reference dose for children ages 3 to 6 for all species, and 6 to 11 for all species, excluding Whitefish. It is recommended that vulnerable populations consuming certain species of fish reduce their intakes or encourage community trading. Furthermore, there is a need for more thorough testing for mercury along the river basin. 


\section{Acknowledgements}

I would like to start by acknowledging my supervisors Dr. Eric Liberda and Dr. Richard Meldrum for their support, guidance and patience throughout this journey.

To the community of Fort Albany First Nation, for sharing their extensive knowledge and providing continuous support, without which this research would not have been possible.

My committee members, Dr. Lynda McCarthy, Dr. Tor Oaimo and Dr. Ronald Puschak, thank you for your guidance and input in these final stages of my thesis. To Dr. Jim Karagatzides and Dr. Leonard Tsuji, thank you for all your guidance and extensive knowledge that have contributed to this research.

To my family, Mohammad Jameel Ahmed, Shohla Jameel, Omair Ahmed, Zohair Ahmed, Layla Kidwai and Marwa Naran. Without your constant support and encouragement, I would not have been able to overcome the challenges and adversities faced to get to this stage.

To my friends, who have kept me going with continuous laughs and some unforgettable memories.

Finally, for all those whose paths I've crossed these last two years that have inspired me, I am truly grateful. 


\section{Table of Contents}

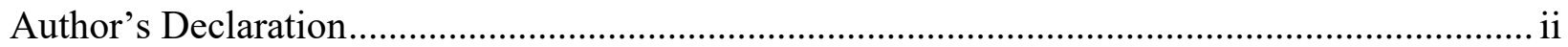

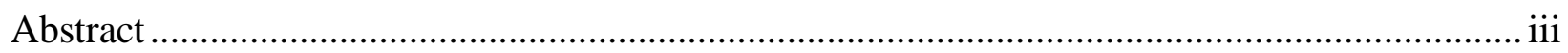

Acknowledgements ........................................................................................................ iv

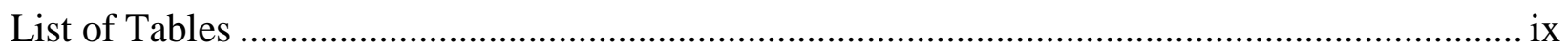

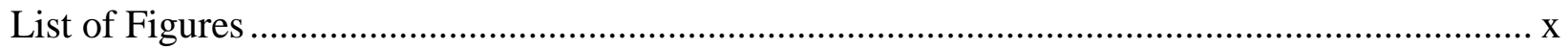

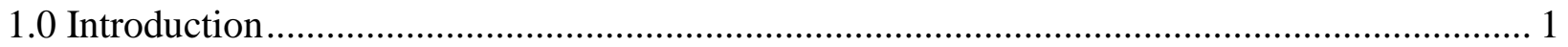

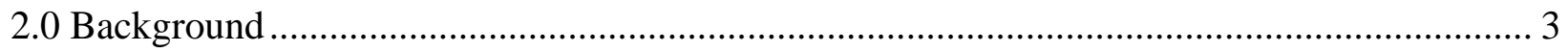

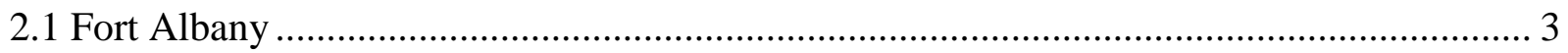

2.1.1 Community Background .................................................................................... 3

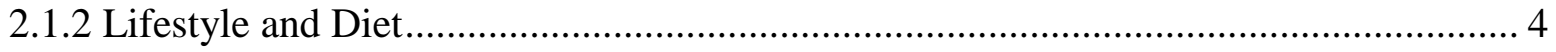

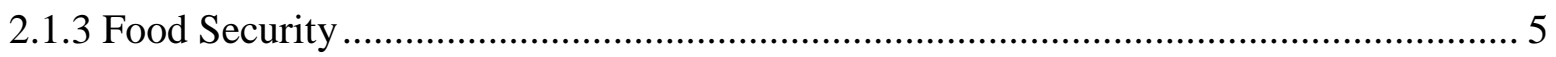

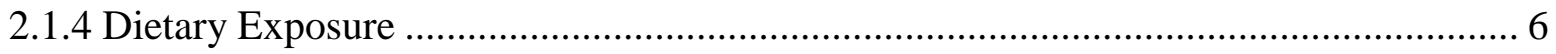

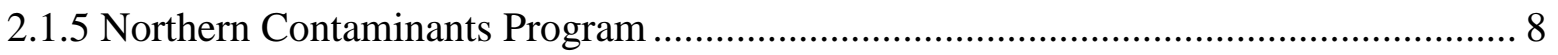

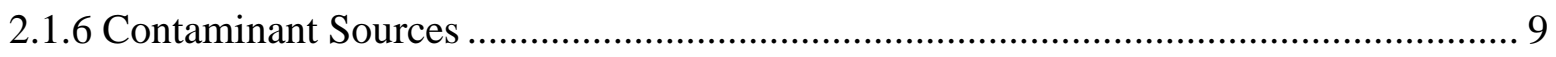

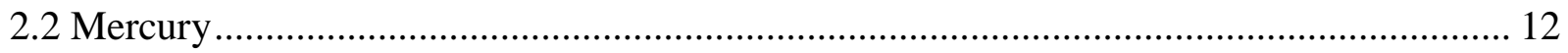

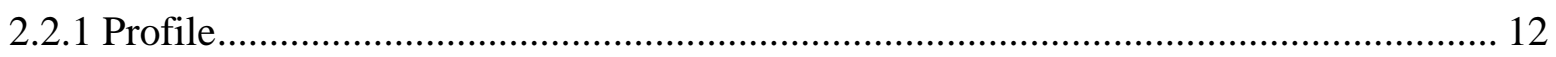

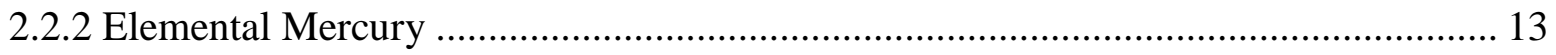

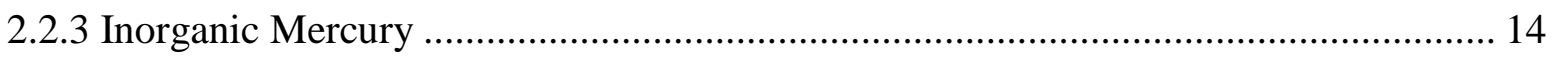

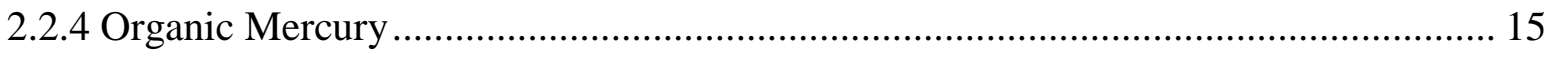

2.2.4.1 Absorption and Distribution ........................................................................... 16

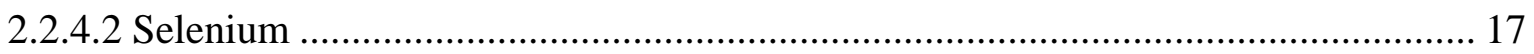

2.2.4.3 Biotransformation ....................................................................................... 18 


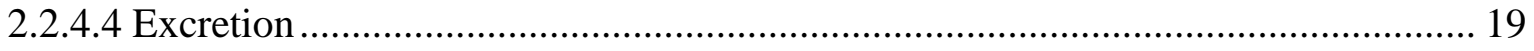

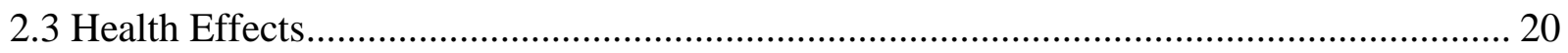

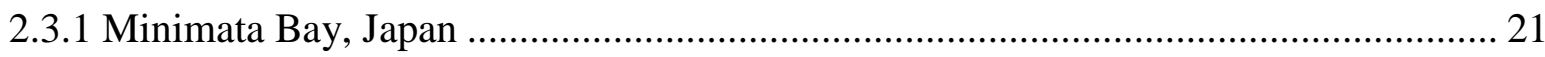

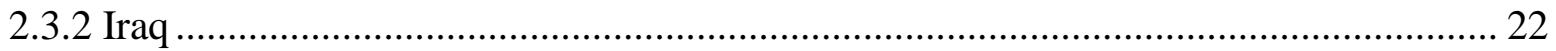

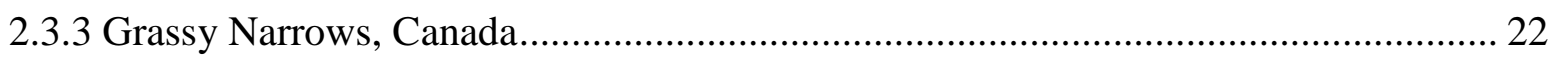

2.4 Methylmercury in Fort Albany First Nation .................................................................. 23

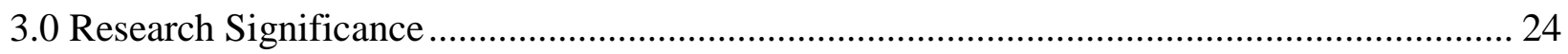

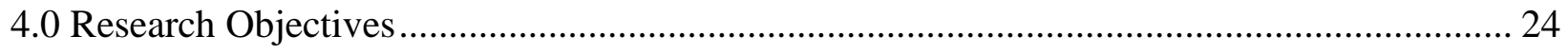

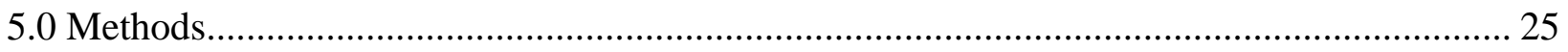

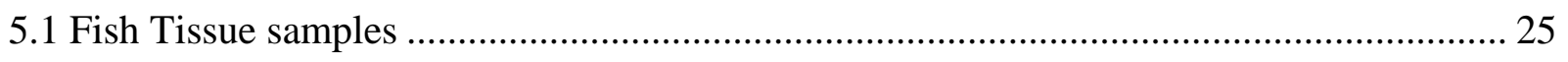

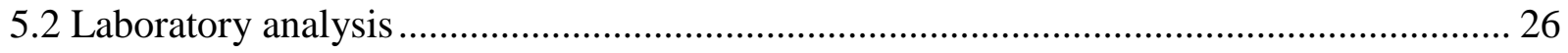

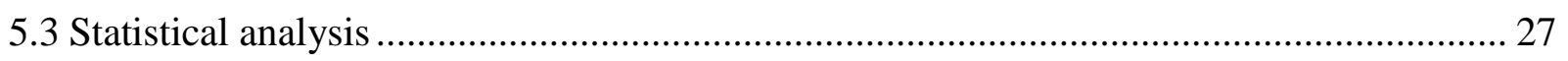

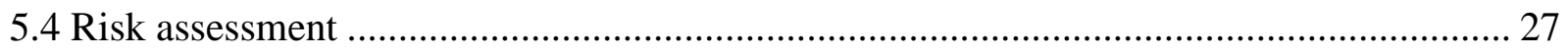

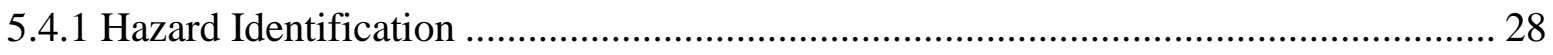

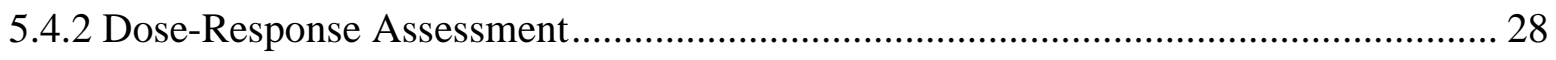

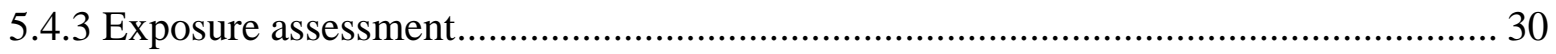

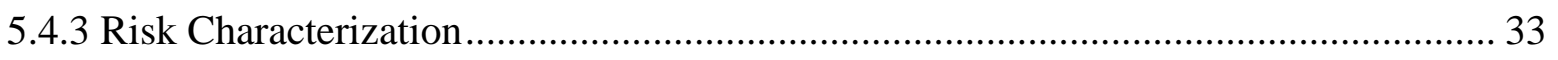

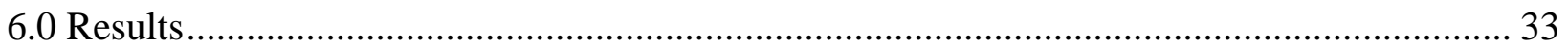

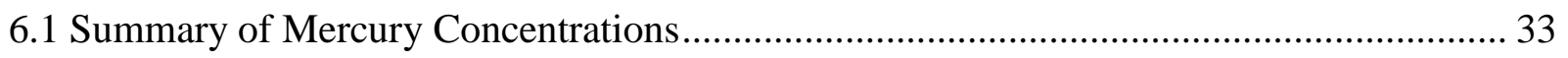

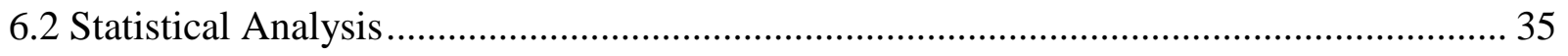

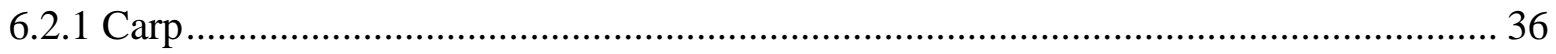

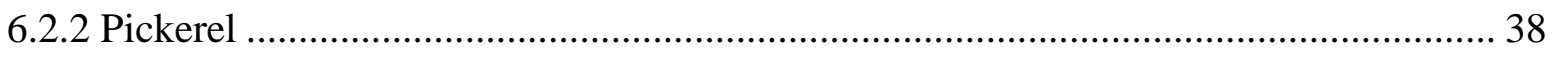

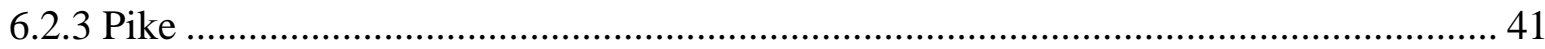




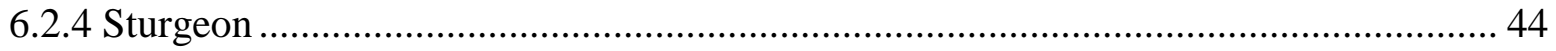

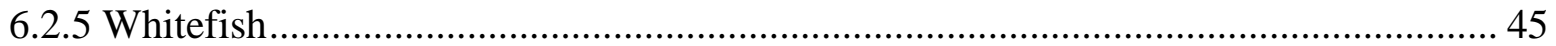

6.3 Summary of Selenium Concentrations ............................................................................ 46

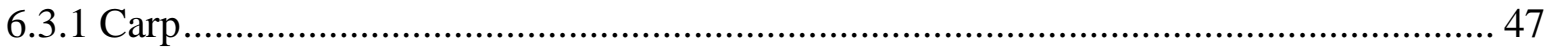

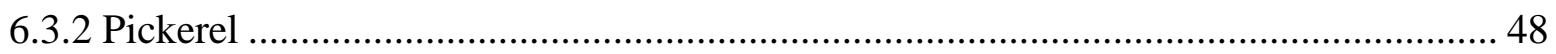

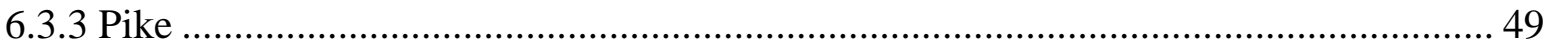

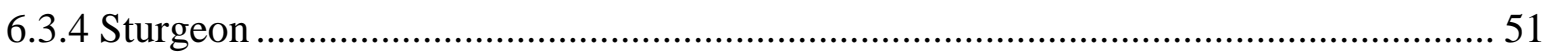

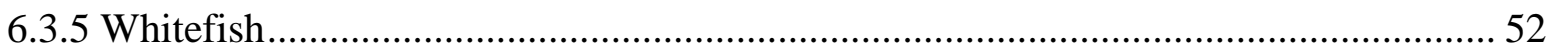

6.4 Human Health Exposure Assessment ...................................................................... 53

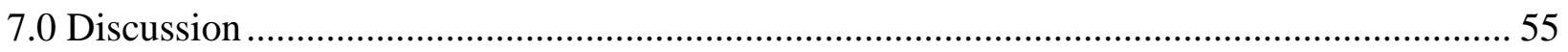

7.1 Statistical Analysis ...................................................................................................... 56

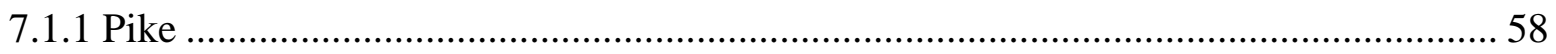

7.2 Human Health Risk Assessment ................................................................................ 59

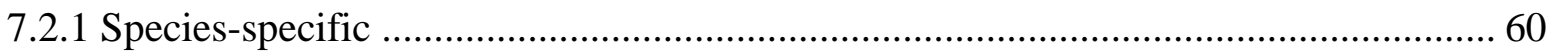

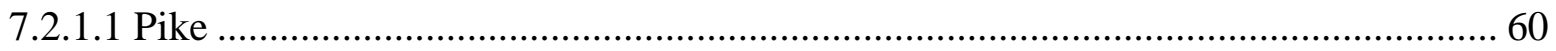

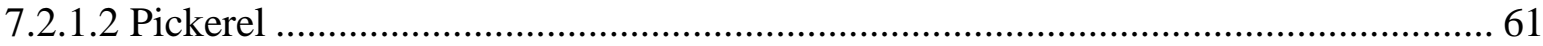

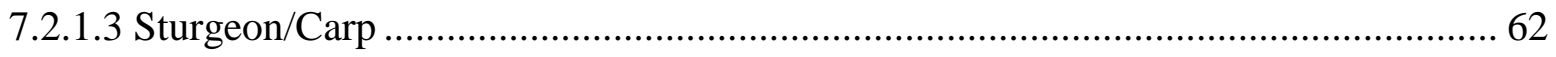

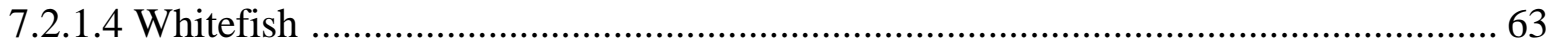

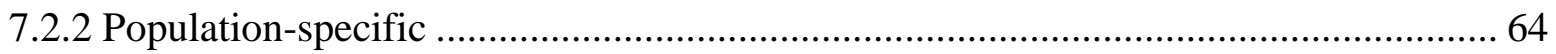

7.2.2.1 Fish Consumption Guidelines.............................................................................. 64

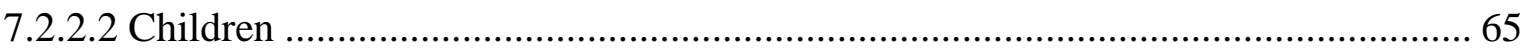

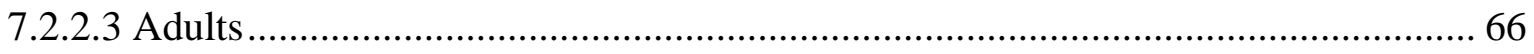

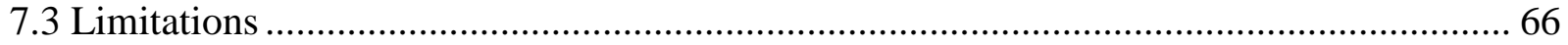




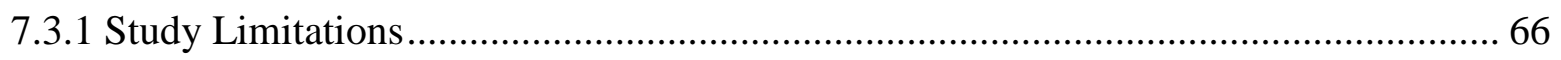

7.3.2 Limitations and uncertainties in Human Health Risk Assessment ......................... 67

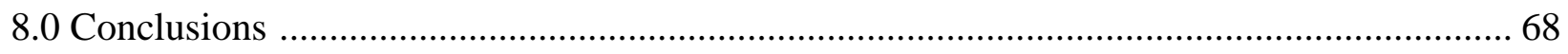

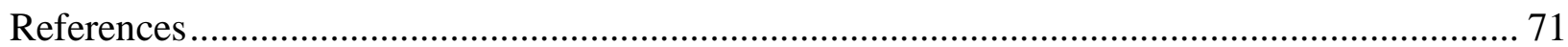




\section{List of Tables}

Table 1. Oral exposure limits for Elemental Mercury, Inorganic Mercury and Methylmercury . 29

Table 2. Sources of variables used to calculate the intake or average daily dose.......................... 31

Table 3. Values of variables used to calculate the intake or average daily dose .......................... 32

Table 4. Descriptive statistics for Total Hg measured in tissues and presented by species ......... 34

Table 5. Descriptive statistics for length measured per species sample ....................................... 34

Table 6. Descriptive statistics for Selenium measured in tissues and presented by species......... 46

Table 7. Summary of the intake and hazard index calculations for all 5 species ........................ 53 


\section{List of Figures}

Figure 1. A map of Fort Albany First Nation, Ontario, Canada............................................... 3

Figure 2. Mean concentrations of Mercury identified per species........................................ 35

Figure 3. Total Hg measured in tissues by length in Carp (2009-2010 samples)..................... 36

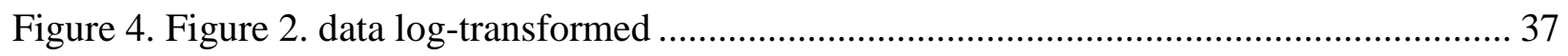

Figure 5. Total Hg measured in tissues by length in Pickerel (2009-2010) ............................. 38

Figure 6. Total Hg measured in tissues by length in Pickerel (2009-2010 and 2011-2012) ....... 39

Figure 7. Total Hg measured in tissues by length in Pike (2009-2010) ................................. 41

Figure 8. Total Hg measured in tissues by length in Pike (2009-2010 and 2011-2012) ............ 42

Figure 9. Total Hg measured in tissues by length in Sturgeon (2009-2010 and 2011-2012) ...... 44

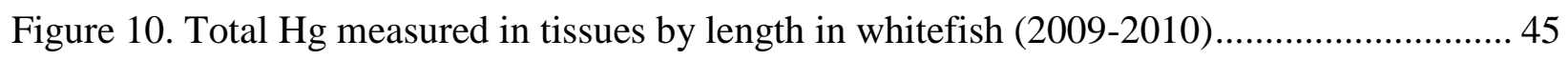

Figure 11. Se measured in tissues by length in Carp (2009-2010) ........................................ 47

Figure 12. Se measured in tissues by length in Pickerel (2009-2010) .................................. 48

Figure 13. Se measured in tissues by length in Pike (2009-2010) ........................................ 49

Figure 14. Se measured in tissues by length in Sturgeon $(2009-2010)$.................................... 51

Figure 15. Se measured in tissues by length in Whitefish $(2009-2010)$.................................. 52 


\section{$\underline{1.0 \text { Introduction }}$}

Traditional diets consisting of food obtained from fishing and hunting have been a crucial part of life in the sub-arctic regions of Canada. These diets have many health benefits, which include an increase in physical activity from fishing and comprise of greater nutritional value in essential nutrients such as vitamin D and Omega-3 fatty acids (Hlimi, 2011). However, in recent years, reduced consumption of traditional foods, and a lack of availability of nutritious food within these areas have contributed to health problems such as diabetes, obesity and cardiovascular disease amongst the population (Damman, Eide, \& Kuhnlein, 2008; Hlimi, 2011; Kuhnlein \& Receveur, 2007; Restoule, Gruner, \& Metatawabin, 2013) Health disparities and increasing challenges to food security have impacted communities such as Fort Albany First Nation, which is located in the western region of James Bay. One of the major reasons for the reduced consumption of traditional foods is the perceptions of potential contamination of fish within these areas due to industry and long-range transport (Assembly of First Nations Environmental Stewardship Unit, 2005; Hlimi, 2011).

Industry developments in resource-rich areas in Canada have contributed to high concentrations of contaminants such as persistent organic pollutants and metals in the environment (Liberda et al., 2011). Though metals such as mercury are present naturally in the earth's crust, they have harmful impacts on human development and cause impairments to the central nervous system (CNS) and damage to organs (Chan \& Receveur, 2000). The health of the fish in and around these areas have suffered similar impacts due to exposure to long-range transport, industry pollution, mining and damming (Assembly of First Nations Environmental Stewardship Unit, 2005). Industries such as the Victor Diamond Mine, which is located in the James Bay Lowlands of Northern Ontario has caused changes in the aquatic structure and 
surrounding biota within the region (Hargan et al., 2016). These projects and developments have caused changes to First Nations communities such as Fort Albany (Liberda, Tsuji, \& Peltier, 2015; Nieboer et al., 2013). These changes create a potential for an increase in leaching of naturally occurring metals such as mercury into the Fort Albany River, causing concerns of methylmercury accumulation through fish in the community. For this reason, there has been an extensive amount of research being completed to address the diversion of consumption of fish in the sub-arctic regions of Canada by First Nations communities (CBHSSJB, 2012; Damstra, Page, Herrman, \& Meredith, 2002; Hlimi, 2011; INAC, 2006; Minkin, Whitelaw, McCarthy \& Tsuji, 2014).

With the exponential growth of Canada's natural resource development, it is important to identify and analyze what the potential impacts are for the communities such as Fort Albany First Nation (CBHSSJB, 2012; Torrie, Bobet, Kishchuk \& Webster, 2005). To address these impacts, it is important to recognize species-at-risk for higher concentrations of contaminants such as methylmercury. Once these species are identified, a human-health risk assessment is a beneficial process which estimates exposures for the surrounding communities', comparative to standards set by government. Based on these standards and biomonitoring, guidelines are created to make recommendations for the consumption of fish. However, there is still a decline in traditional food consumption and community members still remain concerned about mercury exposures through fish. Therefore, the goal of this research was to ultimately assess human dietary exposures to mercury from the Albany River, while remaining respectful to traditional diets, practices, knowledge and lifestyles. 


\subsection{Background}

\subsection{Fort Albany}

\subsubsection{Community Background}

Fort Albany First Nation is a Cree reservation located in the Western region of James Bay $\left(52^{\circ} 15^{\prime} \mathrm{N}, 81^{\circ} 35^{\prime} \mathrm{W}\right)$. The community of Fort Albany First Nation began forming alongside the coast of James Bay following the establishment of the Hudson Bay Company trading posts and through Treaty No.9 (George \& Preston, 1987; McCarthy, Crandall, Whitelaw, General \& Tsuji, 2011).

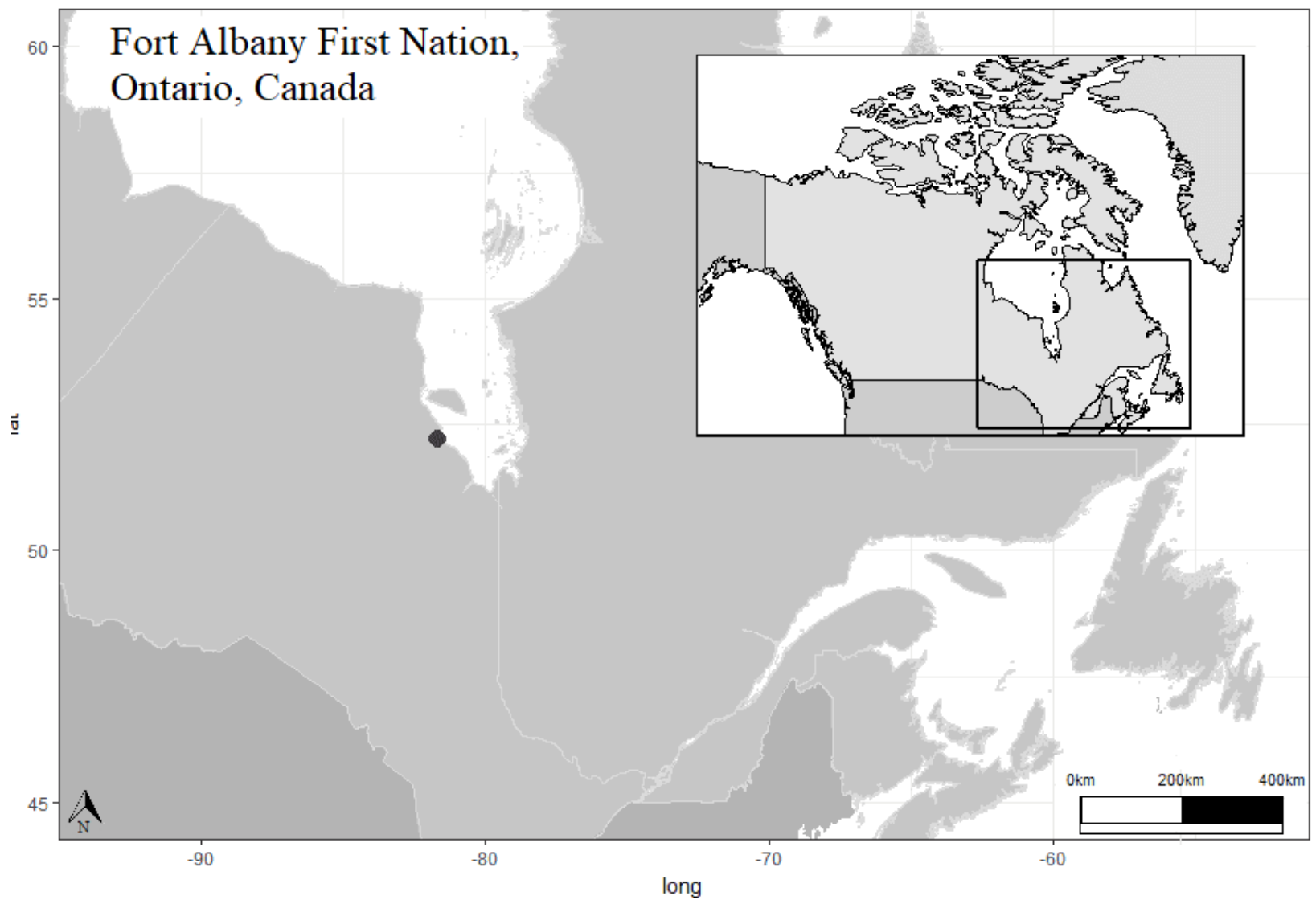

Figure 1. A map of Fort Albany First Nation, Ontario, Canada.

Its location (Figure 1), within a boreal and sub-arctic region, has significantly shaped the lifestyle and diets of the community and provided a habitat for many species (Tam, Gough, Edwards \& Tsuji, 2013). 
With an approximate population of 759 (Statistics Canada, 2017), Fort Albany consists of a sub-arctic climate, which has shaped the culture and lifestyle of the region. Due to the nature of the climate, and its location, Fort Albany First Nation is only accessible by air and a seasonal road referred to as the "winter road". The community is surrounded by major water bodies, mainly the lower western region of James Bay, and three major rivers, the Kistachowan (Albany) river, Moose River and Attawapiskat River, and its connecting arteries. Its geographic location near these major water bodies has significantly influenced the lifestyle and diet of the community.

\subsubsection{Lifestyle and Diet}

The climate in Fort Albany has lead to challenges around food security and, is one of the primary reasons why there is an emphasis on traditional practices such as hunting and fishing, which are an integral part of the lifestyle within the community. The cost of food in Fort Albany is much higher due its location and climate which doesn't allow for year-round crop production (Hlimi, 2011). Nutrient rich foods such as fruits and vegetables cost significantly more and are more difficult to obtain than foods that are easier to transport and store, such as prepacked foods. These foods are generally found to be higher in refined sugars and saturated fats.

Another method of obtaining nutrient rich food is through traditional practices. Fishing is a common method of obtaining food in Fort Albany primarily due to its location near major water bodies such as James Bay, the Kistachowan (Albany) river, Moose river and Attawapiskat river (Restoule et al., 2013). These water bodies, mainly the Kistachowan (Albany) river, are a vital part of the community as they offer a means of transportation, a source of food, and have a tremendous cultural and historical significance. Historically, the mouth of the Albany river was used as a trading post location by the Hudson's Bay Company around 1684 (Restoule et al., 
2013). This led to further developments around the community that will be discussed in later chapters.

Culturally, the river is a crucial part of Fort Albany First Nation and has been a longstanding and significant focus for many of the members of the community. There are varying points along the river that have served as a burial site, demonstrating the connection to ancestors, community members and, the land (Restoule et al., 2013). Generations of community members have integrated the river into the lifestyle and into traditional practices. Traditional practices such as fishing- which is taught by elders pass down knowledge and provide an additional nutritious and, at times cheaper, source of food (Hlimi, 2011). Nevertheless, several studies have illustrated the decline of consumption of high in essential nutrients that protect against chronic disease (Gaudin, Receveur, Walx, Girard \& Potvin, 2014; Kuhnlein, Receveur, Soueida, Berti, 2008; Kuhnlein, Receveur, Soueida, Egeland, 2004).

\subsubsection{Food Security}

According to the Food and Agriculture Organization of the United Nations (FOA) (1996), food security occurs when people "have physical and economic access to sufficient, safe and nutritious food that meets their dietary needs and food preferences for an active and healthy life." Food insecurity exists when people do not have adequate physical, social or economic access to safe food as defined above. Food security has been recognized as a determinant of health and individuals experiencing food insecurity are at a greater risk for many negative health consequences. Issues such as cost, and availability of food is an example of barriers which create issues of food security in remote communities. One of the most apparent health disparities in Canada are those between Indigenous peoples and the non-Indigenous Canadian population. Recent reviews describe the threats to food security for remote First Nations communities as 
urgent and pervasive (Berti et al., 1999; Damman et al., 2008; Hlimi, 2011; Kuhnlein \& Receveur, 2007). Although there exists organochlorine concentration data for fish (McCrea and Fischer, 1986) found in the Western James region, many gaps remain with respect to the concentration of metals and metalloids in fish. In addition, there is a need for assessing the exposure of the most vulnerable population, children, to contaminants through the consumption of fish.

Of importance is the assessment of mercury concentrations in fish. Mercury can be converted to methylmercury $(\mathrm{MeHg})$ in fish and has the ability to biomagnify through aquatic food systems and is highly toxic, due to its neurocognitive and development effects (Depew et al., 2012). However, Selenium(Se) in fish is also commonly assessed due to the potential detoxifying effects of it on methylmercury (Depew et al., 2012). These contaminants, though naturally present in the environment have spread rapidly and become more prevalent due to developments around Fort Albany. Significant developments in the region have occurred in the resource sector such as Ontario Power Generation's hydroelectric developments, along with mining and exploration such as the Victor Diamond mine (Liberda, Tsuji \& Peltier, 2015; Minkin et al, 2014). Though the resource developments within Fort Albany have brought along great benefits such as employment opportunities, they have also caused changes in the lifestyles and diets of the community (Hlimi, 2011).

\subsubsection{Dietary Exposure}

Traditional diets consisting of food obtained from hunting and fishing have been a crucial part of life in the sub-arctic regions of Canada. These diets are deeply rooted in the way of life of many First Nations and have been observed to have many health benefits including an increase in physical activity and greater nutritional value (Assembly of First Nations Environmental 
Stewardship Unit, 2005; Hlimi, 2011). However, in recent years, significant changes in diets within these areas have contributed to health problems among the population. These aforementioned changes in diets within First Nation's communities have brought about higher incidences of chronic disease (Gaudin et al., 2014).

This increased incidence is as a result of a decrease in intake of essential nutrients present in traditional foods that protect against chronic disease (Gaudin et al., 2014; Kuhnlein et al., 2004; Kuhnlein et al., 2008). Diets consisting of fish contribute to an increase in nutrients and minerals such as Omega-3, EPA, DHA, magnesium, iron and selenium which are crucial for functions within the body (Health Canada, 2007b).

Food consumption is the leading pathway for dietary exposure to environmental contaminants (e.g., toxic metals and persistent organic pollutants) (Paustenbach \& Galbraith, 2006). Northern Indigenous subsistence diets consisting of traditional foods (e.g., wild meats, fish) often contain environmental contaminants; however, traditional foods provide an abundance of irreplaceable nutrients not often found in market foods (Health Canada, 2007b). Among Baffin Island children and adolescents, it was identified that any further reduction in traditional food consumption may result in nutritional inadequacy (Berti, Hamilton, Receveur, \& Kuhnlein, 1999). This decrease in traditional food consumption as well as contamination of northern regions of has led to many health problems within communities such as Fort Albany First Nation (Berti et al., 1999; Damman et al., 2008; Kuhnlein \& Receveur, 2007).

This phenomenon known as the Arctic Dilemma, occurs when health-promoting traditional foods may also be detrimental to one's health due to the presence of environmental contaminants carried to northern regions of Canada through atmospheric and oceanic currents, as well as inputs from local point sources (Dewailly, 2006). The Arctic Dilemma can impact 
traditional food consumption as the population shifts to the consumption of non-traditional market food that are often processed and high in refined sugars and saturated fats (Skinner, Hanning, Desjardins \& Tsuji, 2013), which can contribute to obesity, type 2 diabetes, anemia and cardiovascular disease. In addition, traditional foods often contain micronutrients that may not be abundant in market foods. A study done by Receveur, Boulay \& Kuhnlein (1997) found that aquatic species provide roughly $50 \%$ of vitamin A, iron, zinc, protein and copper in Baffin Island adult diets. Despite the clear link between good health and traditional food consumption (Damman et al., 2008; Kuhnlein \& Receveur, 2007) research consistently finds a decreasing reliance on traditional foods among First Nations peoples across Canada (Berti et al., 1999; Hlimi, 2011). This trend is especially apparent among Indigenous adolescents (Berti et al., 1999; Hlimi, 2011).

Increasing concern among First Nations communities regarding the presence of contaminants in their traditional foods, and the health implications of consuming such foods has inevitably resulted in a shift away from eating traditional foods to a diet more reliant on market foods. There is a variety of stressors that influence the food systems of these communities. Industry pollution, mining and damming all impact the safety of the fish (Assembly of First Nations Environmental Stewardship Unit, 2005). For these reasons, there is a need to compile and identify baseline data for the community of Fort Albany First Nation who, to various degrees, rely on food and other resources from the land and therefore are at a higher risk of increased body burdens of triggered by environmental pollutants.

\subsubsection{Northern Contaminants Program}

To help improve health in First Nations communities, Indigenous and Northern Affairs Canada (INAC) created the Northern Contaminants Program in 1991.It is a program that is 
liaised with the federal and territorial governments along with First Nations organizations. Its key objectives are to address concerns of First Nations communities being exposed to high levels of contaminants through traditional foods (INAC, 2006). The Northern Contaminants Program has established a health assessment process, which compares dietary information to contaminant levels in the food, to determine whether it is safe to eat (INAC, 2006). The assessment, however, does not examine human exposure or risk to environmental contaminants. Most exposure research has been conducted on adult subjects; however, there is a paucity of research on children and adolescent subjects (Damstra et al., 2002). Furthermore, no study has yet compared contaminant exposure risks to the nutritional benefits obtained from fish consumption, although the literature gap has been acknowledged (Kuhnlein \& Chan, 2000) Individuals must be aware of both risks and benefits in order to be able to make informed choices about the wild meats and fish that they consume. Being aware of the potential risks from consumption of fish stems from the identification of sources of contamination.

\subsubsection{Contaminant Sources}

Although naturally occurring in sediments, the release of mercury into aquatic ecosystems through anthropogenic sources increases its presence and biomagnification through the aquatic food chain (Porvari, Verta, Munthe \& Haapanen, 2003). As per the Arctic Monitoring and Assessment Program (AMAP) (2009), there has been evidence of the increase of mercury concentrations from pre-industry to current day in aquatic biota. Sources such as mining, hydroelectricity, logging and discharge from industry are all examples of these anthropogenic sources (Hlimi, 2011). Prior to the 1940's, these areas were generally free of industry development, however that changed upon the commencement of hydroelectric development in 
the Albany river, and impacts from the Mid-Canada Radar Line in the 1950's (Tsuji et al, 2006; Whitelaw, McCarthy \& Tsuji, 2009).

Due to the fear of a nuclear attack from the Soviet Union, both Canada and the United Stated agreed to build a series of three radar stations: the Pinetree Radar line, the Mid-Canada Radar Line (MCRL) and the Distant Early Warning Radar (Tsuji et al, 2006). Both countries created the radar lines to detect incoming aircraft or intercontinental ballistic missiles and for dispatch of intercepting planes (Lajeunesse, 2007). In the 1990s both governments closed the radar line sites and locked up the remaining buildings. However, the removal and remediation of the land was a highly important process due to the potential for the release of metals such as mercury that are naturally present in the soil into the aquatic environment (Lajeunesse, 2007; Tsuji et al., 2006; Whitelaw et al., 2009).

Mineral exploration, is also an ever-growing industry around the James Bay Region (Nieboer et al., 2013). The De Beers Victor Diamond Mine, located in Northern Ontario is an example of a mineral exploration company whose activities create a potential for the release of mercury due to its reliance on muskeg for water and drainage (Hlimi, 2011). Through these industries, mercury is also heavily released into the atmosphere when coal is burned, and when processes such as smelting occur, creating opportunity for deposition into aquatic and terrestrial regions (Porvari et al., 2003).

On the eastern side of James Bay, hydroelectric projects such as the 1970s La Grande hydroelectric complex project and the Eastmain-1A and Rupert Diversion project in 2012 played major roles in changing the structure of the environment and increasing the release of contaminants into the water (Nieboer et al., 2013). For these projects, impoundments were created to store river water in reservoirs to ultimately produce electricity (Verdon et al, 1991). 
These reservoirs created flooding in areas where dams are created, increasing the potential for naturally occurring mercury to enter the aquatic systems and be converted to methylmercury (Verdon et al, 1991).

Commercial logging in these regions is also a source of exposure due to its release of mercury into the environment (Hlimi, 2011). In the boreal Canadian Shield forest watersheds, logging increases runoff which deposits an increase of nutrients, dissolved organic carbon and mercury into the lakes (Hlimi, 2011). These areas are also high natural reservoirs for mercury, which deposits into aquatic systems when there is disruption of the land through processes such as logging and mining (Desrosiers, Planas \& Mucci, 2006). Numerous studies have observed and documented the disturbances to watersheds through processes such as logging that significantly increase methylmercury accumulation in the food chain (Desrosiers et al, 2006; Eklöf et al., 2013; Garcia \& Carignan, 1999; Hlimi, 2011; Pirkle, Muckle \& Lemire, 2016).

Industries such as pulp and paper mills have also historically led to the release of mercury in aquatic ecosystems (Mosa \& Duffin, 2017). An overview of the impacts in Grassy Narrows, a community which suffered of the impacts from mercury exposure due to pulp and paper mill effluent, will be detailed in a later chapter. Heavy metals such as mercury have also been sourced to the Arctic from industrialized regions through long-range atmospheric transport (Muckle, Ayotte, Dewailly, Jacobson, \& Jacobson, 2001). Wetlands have been identified as an important source of methylmercury to lakes (Branfireun, Roulet, Kelly \& Rudd, 1999). According to Muckle et al. (2001), mercury reaches its highest concentrations in northern regions through acid rain and contamination through industry. Atmospheric deposition of $\mathrm{SO}_{4}$ in peatlands contributes to an increase in Methylmercury due to the increase of methylation by sulphate-reducing bacteria 
in anoxic sediments (Branfireun et al., 1999; Richardson, Currie \& Egyed, 1995). This is important for boreal and sub-boreal regions such as Fort Albany First Nation.

As he exploration and development around the James Bay region continues to release high concentrations of contaminants such mercury and selenium into the environment (AMAP, 2009). To address the problems these activities cause, programs such as the Artic Monitoring and Assessment Programme (2009), were developed to assess impacts on Arctic ecosystems from pollution and industrialization. It aims to assess impacts from industries and looks at the evaluation and development of protocols for persistent organic pollutants and toxic metals (AMAP, 2009). With the increasing development of industries such as forestry, mining and hydroelectric power within the region of James Bay concerns have been raised regarding the human exposure to contaminants, and to the wildlife which is traditionally consumed (Nieboer et al., 2013).

\subsection{Mercury}

\subsubsection{Profile}

Mercury is a heavy metal that is found within the earth's crust and in the environment in various forms (Pirkle et al., 2016). The three forms that it is present in are elemental, organic and inorganic. These forms create a constant exposure for humans in various media such as air, food, water and in man-made products (Syversen \& Kaur, 2012). As stated by Chan \& Receveur (2000), long term exposure to mercury can cause permanent damage to organs such as the brain and kidneys and to the development of the fetus. As a result, there has been extensive monitoring done of mercury in various regions of the Sub-Arctic by the government (AMAP, 2009; INAC, 2006). 


\subsubsection{Elemental Mercury}

The use of elemental mercury $\left(\mathrm{Hg}^{0}\right)$ over the years has been reduced due to its hazardous nature (Syversen \& Kaur, 2012). With a vapor pressure of $0.00185 \mathrm{~mm}$ at $25^{\circ} \mathrm{C}$, elemental mercury is extremely volatile at room temperature, it presents a potential hazard to humans (Broussard, Hammett-Stabler, Winecker \& Miller, 2002). The high rate of volatilization is why absorption through the lungs is the primary route of exposure. It was noted by Broussard et al. (2002), that long-term chronic exposure in air to elemental mercury vapor over the threshold limit of $0.05 \mathrm{mg} / \mathrm{m}^{3}$ may result in cumulative poisoning, and these exposures may commonly occur in occupational settings. As it is highly lipid soluble, the rate of diffusion across the alveoli into the blood, and through lipophilic compartments such as the blood brain barrier, central nervous system and transplacental exposure are all areas of concern (Broussard et al., 2002). Once mercury passes through the alveoli and enters circulation, it is able to bind to tissues, proteins and erythrocytes, which have the ability to oxidize it into an inorganic metabolite (Broussard et al., 2002). Mercury that has entered the blood brain barrier can be retained for long periods of time following exposure with a half life of approximately 60 days (Harari et al, 2012). In this area, it can be ionized, in which case it is able to carry out its neurotoxic effects.

Elemental mercury has been used in gold mining processes, which can contaminate aquatic environments and result in the formation of its more toxic form, methylmercury. In traditional gold mining, mercury is used to form gold amalgam and then burned to purify the gold and remove the mercury present (Harari et al, 2012). Due to the volatile nature of elemental mercury, an occupational exposure exists for miners who work in gold mines and are exposed to vapours from the process. 
Elemental mercury was also previously used for over 150 years for dental fillings, where $50 \%$ of the amalgam used was composed of metallic mercury (Syversen \& Kaur, 2012). The mercury from these fillings was released by chewing and based on the temperature of the food being consumed (Syversen \& Kaur, 2012). The concerns of potential exposure to elemental mercury through amalgam was addressed by the United States (U.S.) FDA, who deemed it safe for adults and children over the ages of 6 (U.S. FDA, 2017). However, due to the more chronic occupational exposures, dentists are still required to take proper precautionary measures if using amalgam fillings (Syversen \& Kaur, 2012).

\subsubsection{Inorganic Mercury}

Inorganic mercury is generally found in two states, mercurous and mercuric (Broussard et al., 2002). It has been used in items such as antiseptics and skin lightening creams, and other cosmetic and medical products (Syversen \& Kaur, 2012). Exposures to inorganic mercury are similar to those of elemental and organic mercury, primarily through environmental and occupational exposures.

The most common route of exposure for inorganic mercury are oral and dermal impacting the gastrointestinal tract and kidneys due to its solubility (Broussard et al., 2002; Harari et al, 2012; Syversen \& Kaur, 2012). A study done by Oliveira et al. (2015), also detailed the potential for inorganic mercury to gain access to the fetal tissues and organs. In an experimental study on rats, the highest concentration of mercury was detected in the lysosomes and an uneven distribution was present throughout the remaining nervous system (MøllerMadsen, 1992) Excretion of mercury in its inorganic form occurs in feces. 


\subsubsection{Organic Mercury}

Human exposure to organic mercury (methylmercury) has been documented in historic cases such as Minimata Bay, Japan and Grassy Narrows, Canada due to its toxic neurological impacts (Hosokawa, 1993; Mosa \& Duffin, 2017; Skerfving \& Copplestone, 1976).

Methylmercury has been of particular interest due to its ability to bioaccumulate and its neurotoxic impacts and documented history of large scale exposures. Methylmercury has also been documented widely due to its delay period before the onset of symptoms, impacts on the central nervous system and its impacts on the cerebellar granule neurons (Syversen \& Kaur, 2012). Methylmercury is found in the environment as a result of the methylation of elemental mercury, which is readily found in the earths' crust.

When present in an aquatic ecosystem, mercury is transformed through methylation into methylmercury (Graham, Bullock, Maizel, Elias \& Gilmour, 2012). This process occurs through microbial activity by anaerobic or aerobic bacteria, however, the rate of methylation is higher under anaerobic conditions with sulfate-reducing bacteria in sediments (Ullrich, Tanton \& Abdrashitova, 2001). Methylation can occur within bacteria through the transfer of a methyl group from a methyl-corrinoid donor molecule, or outside through the use of bacterial exoenzymes (Ullrich et al., 2001). Methylation can also occur abiotically if methyl donors are present in the environment (Ullrich et al., 2001). Factors that have been identified that may impact this process are $\mathrm{pH}$ levels, salinity and the presence of organic matter (Ullrich et al., 2001).

Organisms can be exposed to the contaminant through ingestion, respiration and absorption from the water (D'Itri, 1991). Due to its lipophilic nature, it can bioaccumulate in an organism, and due to its long half-life, it is also difficult to metabolize and eliminate (D'Itri, 
1991). These characteristics also give it an ability to biomagnify, which results in a higher accumulated dose at the higher trophic levels (Pirkle et al., 2016). Methylmercury is the only form of mercury which is able to biomagnify throughout the food chain, making it a very potent contaminant in the environment (D'Itri, 1991).

\subsubsection{Absorption and Distribution}

Organisms can be exposed to the contaminant through ingestion, respiration and absorption from the water (D' Itri, 1991). Inhalation exposures of methylmercury depend on particle size and characteristics; however, about $80 \%$ is retained after exposure (Syversen \& Kaur, 2012). The mercury exposure route studied in this thesis is primarily via the diet. This is one of the most important routes of exposure as increased methylmercury in fish species creates an opportunity for accidental exposures in communities. Once ingested, methylmercury is separated by gastric acid and can combine with cysteine in the duodenum and be entirely absorbed (Hong, Kim \& Lee, 2012). When methylmercury is absorbed, it is able to bind to blood and tissue proteins by attaching onto sulfhydryl groups such as glutathione and cysteine, which allows it to be transported through membranes (Syversen \& Kaur, 2012). This creates a risk to the placenta and ultimately the brain of the fetus. Methylmercury also has the ability to be transported by passive diffusion (Syversen \& Kaur, 2012).

According to Hong et al (2012), 90\% of methylmercury is distributed in red blood cells, therefore, measuring the blood provides an inference about the concentration present in other organs. The distribution of methylmercury into the brain also occurs through the assistance of carrier proteins. Methylmercury is able to combine with cysteine to form a structure similar to methionine, which is then accepted by the large neutral amino acid carrier of the capillary endothelial cells (Graham et al., 2012). Concentrations in hair were also previously believed to 
be proportional to blood ratios (Hong et al., 2012); however, studies have shown that blood concentrations provide a more accurate representation of the concentration of methylmercury (Liberda et al., 2014a). As it is readily absorbed and can be transported by the blood, it is important to understand the potential biotransformation which can occur once absorbed. Though methylmercury has the potential to readily be absorbed and distributed, certain contaminants such as selenium, have been documented to counteract methylmercury due to its binding ability.

\subsubsection{Selenium}

Selenium is a naturally occurring element which is found in the earth's crust. It is generally found in a -II oxidation state, and is released from rocks (Torres et al., 2011). When in aquatic ecosystems, selenium has the ability to bioaccumulate throughout the aquatic food chain. Rates of selenium vary greatly depending on geo-environmental factors and are generally found as organoselenium compounds (Torres et al., 2011). A report by the Joint Food and Agriculture Organization (FAO) \& World Health Organization (WHO) (2002), proposed a recommended nutrient intake of $26 \mu \mathrm{g} /$ day in adult women (19+) and $34 \mu \mathrm{g} /$ day men $(65 \mathrm{~kg})$, respectively for selenium. Fish has been shown to be one of the most common sources of selenium in diets, therefore, assessing selenium is key in dietary exposures of fish.

Selenium (Se) has been documented since 1967 as having the ability to counteract the effects of methylmercury exposures (Parízek \& Ostádalová, 1967). Selenium is an essential trace element found in humans as it can act as a growth factor, plays a role in developmental reproduction and is essential for thyroid hormone homeostasis (Ralston \& Raymond, 2011). Selenium has been recognized for its ability to counteract and eliminate symptoms of methylmercury exposures. This is due to mercury's binding affinity for selenium and several mechanisms which contribute to these effects (Syversen \& Kaur, 2012). Mercury's high affinity 
to selenium compromises selenium's functions and availability in the body by sequestering it at active sites of essential selenium-dependent enzymes (Ralston \& Raymond, 2011). Insoluble Hg selenides are formed and reduce the amount of selenium available for selenoprotein synthesis, which is important for preventing oxidative damage to the brain and for redox control (Ralston \& Raymond, 2011). When there is an increase in selenium, it ensures there is sufficient selenium in place to prevent the depletion of selenium for its essential functions. Therefore, it is important to understand the level of exposure and the concentrations present of both methylmercury and selenium. The increased awareness about the effects of selenium on methylmercury exposures is critical to helping mitigate some of the impacts of exposures.

\subsubsection{Biotransformation}

Methylmercury undergoes oxidation and reduction to biotransform into its inorganic form in the body, and this occurs in sites such as the liver and tissues (Yasutake \& Hirayama, 2001). The liver is the main site of biotransformation of methylmercury and allows for its metabolites to be excreted into the bile and enter the intestine so that it can be excreted in the feces (Klaassen, Casarett \& Doull, 2013). This process is also important as it removes contaminants from the blood after they're absorbed from the gastrointestinal tract and prevents them from being distributed elsewhere (Klaassen et al., 2013).

Once undergoing this demethylation process, methylmercury produces oxygen radicals and damages cells by activating the chain of lipid peroxidation of the cell membrane (Hong et al., 2012). Studies by Gage (1975), have also identified $\gamma$-globulin and serum albumin having the potential to degrade methylmercury to mercuric $\mathrm{Hg}$ by glutathione. Though the distribution and excretion of methylmercury are well documented, the enzymes responsible for active demethylation process in mammals have not yet been identified (Chen \& Riggs, 2011; National 
Research Council, 2000). The extensive reabsorption of methylmercury is thought to contribute to the biological half-life of 70 days and toxicity (Klaassen et al., 2013). It is important to note, however, that the half-life is much shorter in breastfeeding women due to the excretion of methyl mercury through breast milk (Hong et al, 2012).

\subsubsection{Excretion}

Excretion of methylmercury occurs through several routes. Methylmercury is primarily excreted through the bile, breastmilk, and feces (Syversen \& Kaur, 2012; Hong et al, 2012). In a study done by Magos \& Clarkson (2008), it was identified that hair accounts for $7 \%$ of elimination from the body and varies significantly based on individual characteristics.

Elimination through bile occurs during enterohepatic cycling where it is either reabsorbed and returned to the liver or excreted with feces (Syversen \& Kaur, 2012). The primary excretion route for methylmercury is through the feces as it is demethylated and excreted in ion form (Hong et al., 2012). The excretion likely occurs by passive diffusion out of enterocytes or, by exfoliation of intestinal cells during the normal turnover of the epithelium (Klaassen et al., 2013). Enzymes found in the intestine hydrolyze glucuronide and sulfate conjugates which create a more lipophilic compound and increase the likelihood of reabsorption (Klaassen et al., 2013). Reabsorption creates an opportunity for mercury to return to the liver where it can be metabolized and excreted into the bile (Klaassen et al., 2013). Polythiol resin has been used previously to interrupt this cycle and prevent the reabsorption of methylmercury (Klaassen et al., 2013).

Methylmercury may also be excreted through breastmilk. This is an important route of exposure as it can pass on to offspring. This process occurs through simple diffusion, as the 
lipid-soluble products such as methylmercury diffuse along with fats from plasma into the mammary glands (Klaassen et al., 2013).

\subsection{Health Effects}

Methylmercury is of particular concern to human health due to its presence in water bodies, its ability to biomagnify through the food chain and be ingested by humans through fish and shellfish. The health effects of methylmercury have been widely studied clinically and have been greatly documented through cases such as Minimata Bay, Japan, which will be discussed in further detail in chapter 2.3.1. There have been studies completed to date that have identified a direct relationship between methylmercury exposure and an increase in cancer occurrence; however, there are minimal data to develop risk slope factors, deeming it a Group 2B (possibly carcinogenic to humans) through the International Agency on Cancer and, a Group C (possible human carcinogen) through the EPA (Hong et al., 2012). Therefore, neurotoxic, reproductive and cardiovascular impacts are examined as non-carcinogenic impacts for methylmercury exposures as they are much more significant.

The neurotoxic effects of methylmercury have been documented through high and low concentration exposures (Depew et al., 2012). Methylmercury is a potent neurotoxic that “influences enzymes, cell membrane function, and neuron delivery materials; causes oxidative stress, lipid peroxidation, and mitochondria dysfunction and distracts synapse transmission, microtubule composition, amino acid transport and cellular migration in growing brains" (Grandjean et al, 1997). Impacts on motor functions have also been observed through disturbances such as ataxia, trembling, impaired hearing and vision (Hong et al., 2012).

Reproductive impairments are also a significant impact of methylmercury exposure. In animal studies, a correlation between chromosomal anomaly and sister-chromatid exchange were 
identified (Hong et al., 2012). Toxicological studies showed that high concentrations of methylmercury also showed a reduction in sperm count, reduced infant size, reduced survival rates, deformities reported at birth and testicular atrophy (Hong et al., 2012). Impacts on birth weight have also been studied in relation to methylmercury exposures through assessment of cord blood mercury concentrations (Karagas et al, 2012). However, due to many uncertainties and underlying variables in these studies, it is difficult to determine with certainty the impact of methylmercury exposures on fetal growth; nevertheless, studies have shown a possible effect (Karagas et al, 2012).

Although generally, methylmercury exposure is studied for its impacts on the central nervous system, the cardiovascular system is also one that may be impacted through varying levels of exposure. These impacts are more severe in adults than in children. Methylmercury disturbs the anti-oxidation effects of glutathione and catalase due to its high affinity with the thiol group, therefore causing lipid peroxidation which can further promote platelet aggregation, blood coagulation, and impact arteries and blood pressure (Hong et al., 2012). In a meta-analysis by Karagas et al (2012), studies demonstrated impacts such as myocardial infarction, impacts on blood pressure, heart rate variability and atherosclerosis. However, in a study done by Rissanen, Voutilainen, Nyyssönen, Lakka, \& Salonen (2000), it was reported that fish oil-derived fatty acids, such as those obtained through a diet consisting of fish and shellfish, reduced the risk of acute coronary effects. The impacts of Methylmercury were observed across the globe through large-scale exposures in Japan, Iraq and Canada.

\subsubsection{Minimata Bay, Japan}

As one of the most widely documented cases of methylmercury poisoning, in 1956,

Minimata Bay, Japan set a precedent for the implications of the effects of methylmercury. As a 
result of a chemical factory releasing large amounts of mercury effluent into Minimata Bay between 1932 to 1968, there was a significant accumulation in aquatic species of methylmercury (Hosokawa, 1993). Members of the community who had consumed large amounts of fish taken from the bay were exposed to high concentrations. Symptoms such as numbness, developmental disorders, developmental impacts to extremities, paralysis and loss of hearing, vision and speech were identified and attributed to the exposures in 1956 (D' Itri, 1991). Concentrations ranging from 280 to $760 \mathrm{ppm}$ were detected (Hong et al, 2012). The impacts of these exposures were first discovered in fetuses that were showing impairments of brain development. In a study done by Harada (1995), it was identified that over 2252 people had been impacted by what was termed Minimata disease, with over 1043 deaths.

\subsubsection{Iraq}

Between 1971 and 1972, a case of methylmercury poisoning was documented due to the consumption of seeds that were treated by fungicides including those containing organomercury compounds (Skerfving \& Copplestone, 1976). 409 deaths were reported as a result of the exposure which was documented as being higher than that observed in Minimata Bay (Hong et al, 2012). Ranges of concentrations were observed between $25 \mathrm{mg}$ and $200 \mathrm{mg}$ with symptoms such as cerebral palsy, dysesthesia, paralysis and mental health disorders being observed (Skerfving \& Copplestone, 1976). Historic exposures such as these which occurred by food contamination are extremely important as they highlight the impacts from acute and long-term exposure to methylmercury.

\subsubsection{Grassy Narrows, Canada}

Residents of Grassy Narrows, Ontario reported witnessing a degradation of the ecosystem with wildlife disappearing and dead fish appearing in the river (Mosa \& Duffin, 2017). The 
contamination of the Grassy Narrows and Whitedog region occurred as a result of Dryden mill, a paper and pulp plant, dumping mercury effluent into the Wabigoon River system between 1962 and 1970 (Mosa \& Duffin, 2017). Over 10 metric tonnes of mercury were released into the English-Wabigoon River (Hlimi, 2011). When patients began exhibiting symptoms similar to those witnessed in Minimata Bay, Dr. Masazumi Harada completed an analysis of hair samples in which 87 residents were over the safe limit, 61 were between 100-199 ppb and 26 exceeded 200 ppb (Mosa \& Duffin, 2017). Symptoms which were documented included impaired hearing and speech, paresthesia and sensory impairments (Takaoka et al, 2014).

\subsection{Methylmercury in Fort Albany First Nation}

Due to the historically documented impacts of methylmercury exposure, the risk of potential exposure to any population, especially First Nation's communities, is a cause for concern. Traditional practices such as fishing, which contribute to an increase in nutritional intake for the population and increase in physical activity, are susceptible to being impacted by mercury. Mercury is able to bioaccumulate and biomagnify in aquatic environments, creating an opportunity for exposure to high levels of mercury. Communities such as Fort Albany First Nation which are impacted by issues of food security because of its geographic location and climate, benefit greatly from traditional practices of obtaining food through fishing. Industry developments of hydroelectric damming and, historic sources such as the Mid-Canada Radar Line have led to the release of mercury in aquatic systems such as the Albany River. For this reason, it is crucial to identify what the level of mercury is within the river, specifically within the fish population that is consumed. The potential of mercury exposure in Fort Albany First Nation puts the entire community, including vulnerable populations such as the elderly, children and pregnant women at risk of the detrimental impacts following exposure. 


\subsection{Research Significance}

This research aimed to identify human exposure to mercury within Fort Albany First Nation while remaining respective of traditional diets, practices and knowledge. Traditional diets amongst First Nations communities have been identified as an important route of exposure for contaminants (AMAP, 2005; Liberda et al, 2014b; Nøst et al., 2013). Although there exists organochlorine concentration data for the western James region (Braune et al., 2005; McCrea and Fischer, 1986) many gaps remain with respect to the concentration of metals and metalloids in fish in water. The increasing industry developments around Fort Albany First Nation, and longrange transport of contaminants have led to potential for increased mercury in the environment. For these reasons, members of the community may be at a higher risk of adverse health effects from these exposures.

In addition, there is a need to assess the exposure of the most vulnerable population, children, to contaminants through the consumption of fish. The potential of metals and metalloids impacting the health of First Nations children is a growing concern; thus, the project provides invaluable information of a potential route of contaminant exposure (the traditional diet) and baseline data on which to base future fish monitoring studies with respect to hydro-electric development on the Albany River. Health care professionals and First Nations can use this knowledge to inform strategies and program planning activities, and to advocate for policies at the local, provincial and federal levels to assess, build and strengthen community food security, specifically in remote-northern, First Nations communities.

\subsection{Research Objectives}

This study aimed to understand and evaluate human dietary exposure to mercury from a traditional diet of locally-sourced fish in Fort Albany First Nation. The objectives of this study 
were to address concerns of mercury exposure which has deterred community members from traditional fish consumption. The objectives of this study were the following,

1. Complete a dietary human health risk assessment using dose-response values obtained from Health Canada, and

2. Determine the concentration of mercury in wild fish consumed in comparison to consumption guidelines, and

3. Establish baseline concentrations of mercury in fish of the Fort Albany River basin, as further hydro-electric development has been proposed for the Albany River.

\section{$\underline{5.0 \text { Methods }}$}

\subsection{Fish Tissue samples}

Fish samples were collected by community members from Fort Albany First Nation. The samples which were obtained and analyzed were of northern pike (Esox Lucius), pickerel (Esox Niger), lake sturgeon (Acipenser fulvescens), longnose carp, (Catostomus catostomus) and whitefish (Coregonus clupeaformis). These samples were selected based on the availability of species which were caught during the study period. Specimens were selected randomly from the catch during the summers of 2009-2010 and 2011-2012 to augment archived specimens (northern pike, Esox lucius, n = 28; pickerel, Esox Niger, n = 15; lake sturgeon, Acipenser fulvescens, $\mathrm{n}=9$; longnose carp, Catostomus catostomus, $\mathrm{n}=21$; and whitefish, Coregonus clupeaformis, $\mathrm{n}=13$ ). Samples were collected at south channel of the Albany River. Fork length (the measurement taken from the anterior-most part of the fish to the end of the median caudal fin-rays) was measured to the nearest centimeter and fish weighed to the nearest gram. Length is a standardize measurement when assessing methylmercury exposures as length is a reflection of age, and the stage of its lifecycle that the fish is in. Fish were sealed in plastic bags and stored 
frozen until dissection or processed immediately when fresh. Samples were dissected using stainless steel blades (blades were washed, and then rinsed with distilled water) in the field and a portion of the fillet was placed in Nalgene wide-mouth containers and shipped frozen to the laboratory for analysis. Archived fish samples were treated in the same way.

\subsection{Laboratory analysis}

The Centre de Toxicologie du Quebec (CTQ), which is an ISO accredited laboratory and the North American reference laboratory for the Arctic Monitoring and Assessment Program, analyzed the tissues samples. The laboratory also coordinates inter-laboratory quality control programs (CTQ, n.d.). The metals, mainly mercury [total and organic] and selenium were measured by inductively coupled plasma mass spectrometry (ICP-MS; Elan 6000, PerkinElmer, Shelton, CT, USA), after digestion of the samples. Accuracy was assessed using certified reference materials and variation coefficients $(\mathrm{CV})$ were estimated to evaluate precision. All CVs were below 10\%. Detection limits (DL) were $<0.1 \mu \mathrm{g} / \mathrm{g}$ wet weight for selenium; while, the DL for mercury [total] was $<1 \mathrm{nmol} / \mathrm{g}$. All samples that had detectable levels of total mercury and enough tissue remaining (i.e., carp, $n=21$; pickerel, $n=15$; pike, $n$ $=26$; sturgeon, $\mathrm{n}=8$; whitefish, $\mathrm{n}=6$ ) were analyzed by cold vapor atomic absorption spectroscopy to determine concentrations of inorganic mercury (DL $<1 \mathrm{nmol} / \mathrm{g}$ ).

It is important to note, in these species, total $\mathrm{Hg}$ is reported. Inorganic mercury (ie. Nonmethylmercury) was detected in only one sample (1.5 nmol/g in a sturgeon $)$ using atomic absorption spectroscopy. As stated by the WHO (2008), for fish consuming populations, such as remote indigenous populations who are dependent on fish for their diet, total $\mathrm{Hg}$ concentrations may be used instead of MeHg concentrations for the risk assessment. It is assumed that all 
mercury in hair and blood is methylmercury therefore justifying the use of Total $\mathrm{Hg}$ in analysis (Liberda et al, 2014a).

\subsection{Statistical analysis}

Concentrations for total mercury in $\mathrm{nmol} / \mathrm{g}$ were converted to $\mu \mathrm{g} / \mathrm{g}$ to be comparable to the Health Canada consumption guidelines for total mercury in fish tissue of $0.5 \mu \mathrm{g} / \mathrm{g}$ wet weight $(0.5 \mu \mathrm{g} / \mathrm{g}=2.4925 \mathrm{nmol} / \mathrm{g})$ (Health Canada, 2007b). For duplicate measured values of mercury and selenium, the original value was used in all calculations. Descriptive statistics were generated utilizing wet weight data. Levels below the detection limit (DL) were imputed as $1 / 2$ the DL, when appropriate. Linear regression analysis was used to examine the relationship between body weight and total mercury and selenium for species, when sample sizes were adequate. A standard p value of 0.005 was used to determine statistical significance of the results obtained.

\subsection{Risk assessment}

A risk assessment is used to identify and determine the health effects because of anticipated or known exposures to populations (National Research Council, 1983). The adverse health effects were measured as carcinogenic (causing cancer), or non-carcinogenic, which may result in any other adverse health effect. The risk assessment process can be best described using the 4-step model as follows (National Research Council, 1983; Paustenbach, 2002):

1. Hazard Identification

2. Dose-response assessment

3. Exposure Assessment:

4. Risk Characterization 


\subsubsection{Hazard Identification}

The first step of the risk assessment process is hazard identification. During this step, the main goal is to determine whether the contaminant of interest, in this case methylmercury, is associated with the defined health effects. As stated in Section 2.3, methylmercury is a hazard to human health. A more in-depth analysis regarding the toxicokinetics and toxicodynamics of mercury and its various forms are detailed in Section 2.2.4. For its associated health impacts, methylmercury has been well documented for its neurotoxic and developmental impacts, as seen in major incidents occurring in Japan, Iraq and most recently Grassy Narrows, Ontario (Bakir et al., 1973; Hosokawa, 1993; Wong, 2017). For these reasons, methylmercury was identified as a hazard and dietary exposures through traditionally consumed fish were analyzed for the purposes of this study.

\subsubsection{Dose-Response Assessment}

During this step of the risk assessment, the primary goal is to determine the relationship is between exposure and the probability of the defined health effect occurring. In the case of noncancerous exposures, a non-linear dose response is assumed.

For the three forms of mercury, elemental, inorganic and organic, Table 1 provides a compilation of data that identifies the various limits set for oral exposures. These values identify bench mark levels for exposure that decrease the likelihood of adverse effects. Compared to other regions such as the EU and Japan, the values set by Health Canada are more conservative limits. 
Table 1. Oral exposure limits for Elemental Mercury, Inorganic Mercury and Methylmercury

\begin{tabular}{|c|c|c|c|}
\hline Chemical & Value & Value & Source \\
\hline \multirow[t]{4}{*}{$\begin{array}{l}\text { Elemental } \\
\text { Mercury }\end{array}$} & $L O A E L$ & $0.5 \mathrm{ppm}$ mercury & $\begin{array}{l}\text { (US Department of Health } \\
\text { and Human Services, } \\
\text { ATSDR, 1989) }\end{array}$ \\
\hline & $R f D$ & $0.5 \mu \mathrm{g} / \mathrm{g}$ wet weight & (Health Canada, 2007b) \\
\hline & $\begin{array}{l}\text { PTWIs: Joint } \\
\text { FAO/WHO Expert } \\
\text { Committee on Food } \\
\text { Additives (JECFA) }\end{array}$ & $5 \mathrm{mg} / \mathrm{kg}_{\mathrm{bw}} /$ day & $\begin{array}{l}\text { (WHO \& UNEP DTIE } \\
\text { Chemicals Branch, 2008) }\end{array}$ \\
\hline & $\begin{array}{l}\text { Action Level in } \\
\text { fishery products } \\
\text { (Japan) }\end{array}$ & $0.4 \mathrm{mg} / \mathrm{kg}_{\mathrm{bw}}$ & $\begin{array}{l}\text { (WHO \& UNEP DTIE } \\
\text { Chemicals Branch, 2008) }\end{array}$ \\
\hline \multirow[t]{2}{*}{$\begin{array}{l}\text { Inorganic } \\
\text { Mercury }\end{array}$} & $\begin{array}{l}\text { RfD [Mercuric } \\
\text { chloride] }\end{array}$ & $0.3 \mathrm{mg} / \mathrm{kg}_{\mathrm{bw}} /$ day & $\begin{array}{l}\text { (US Department of Health } \\
\text { and Human Services, } \\
\text { ATSDR, 1989) }\end{array}$ \\
\hline & LOAELs & $\begin{array}{l}\text { Ranging from } 0.23 \text { to } 0.63 \\
\mathrm{mg} / \mathrm{kg}_{\text {bw }} / \text { day }\end{array}$ & $\begin{array}{l}\text { (US Department of Health } \\
\text { and Human Services, } \\
\text { ATSDR, 1989) }\end{array}$ \\
\hline \multirow[t]{10}{*}{$\begin{array}{l}\text { Methyl } \\
\text { Mercury }\end{array}$} & $M R L$ & $\begin{array}{l}0.0003 \mathrm{mg} / \mathrm{kg}_{\mathrm{bw}} / \text { day (chronic- } \\
\text { duration, i.e. } 365 \text { days or more) }\end{array}$ & $\begin{array}{l}\text { (US Department of Health } \\
\text { and Human Services, } \\
\text { ATSDR, 1989) }\end{array}$ \\
\hline & $\begin{array}{l}\text { Tolerable Daily } \\
\text { Intake/ Reference } \\
\text { Dose }\end{array}$ & $0.1 \mu \mathrm{g} / \mathrm{kg} / \mathrm{day}$ & $\begin{array}{l}\text { (United States (U.S.) } \\
\text { Environmental Protection } \\
\text { Agency, 2001) }\end{array}$ \\
\hline & Over 13 & $0.00047 \mathrm{mg} / \mathrm{kg}_{\mathrm{bw} / \mathrm{d}}$ & (Health Canada, 2010) \\
\hline & ages under 13 & $0.0002 \mathrm{mg} / \mathrm{kg}_{\mathrm{bw} / \mathrm{d}}$ & (Health Canada, 2010) \\
\hline & $\begin{array}{l}\text { Action Level for } \\
\text { finfish/shellfish }\end{array}$ & $1 \mathrm{mg} / \mathrm{kg}_{\mathrm{bw}} /$ day & $\begin{array}{l}\text { (WHO \& UNEP DTIE } \\
\text { Chemicals Branch, 2008) }\end{array}$ \\
\hline & $\begin{array}{l}\text { Action Level in } \\
\text { fishery products: } E U\end{array}$ & $0.5 \mathrm{mg} / \mathrm{kg}_{\mathrm{bw}} / \mathrm{day}$ & $\begin{array}{l}\text { (WHO \& UNEP DTIE } \\
\text { Chemicals Branch, 2008) }\end{array}$ \\
\hline & $\begin{array}{l}\text { Action Level in } \\
\text { fishery products: } \\
\text { Japan }\end{array}$ & $0.3 \mathrm{mg} / \mathrm{kg}_{\mathrm{bw}} /$ day & $\begin{array}{l}\text { (WHO \& UNEP DTIE } \\
\text { Chemicals Branch, 2008) }\end{array}$ \\
\hline & $\begin{array}{l}\text { PTWIs: Joint } \\
\text { FAO/WHO Expert } \\
\text { Committee on Food } \\
\text { Additives (JECFA) }\end{array}$ & $1.6 \mathrm{mg} / \mathrm{kg}_{\mathrm{bw}} /$ day & $\begin{array}{l}\text { (WHO \& UNEP DTIE } \\
\text { Chemicals Branch, 2008) }\end{array}$ \\
\hline & $\begin{array}{l}\text { Steady-state daily } \\
\text { ingestion rate }\end{array}$ & $\begin{array}{l}1.5 \mathrm{mg} / \mathrm{kg}_{\mathrm{bw}} / \text { day, result in the } \\
\text { concentration in maternal blood } \\
\text { estimated to be without appreciable } \\
\text { adverse effects in the offspring }\end{array}$ & $\begin{array}{l}\text { (WHO \& UNEP DTIE } \\
\text { Chemicals Branch, 2008) }\end{array}$ \\
\hline & & $\begin{array}{l}1.6 \mathrm{mg} / \mathrm{kg}_{\mathrm{bw}} / \text { week, remained } \\
\text { appropriate for protection of the } \\
\text { most vulnerable life stages, the } \\
\text { embryo and fetus }\end{array}$ & $\begin{array}{l}\text { (WHO \& UNEP DTIE } \\
\text { Chemicals Branch, 2008) }\end{array}$ \\
\hline
\end{tabular}




\subsubsection{Exposure assessment}

Exposure assessments are completed to determine to what the extent human exposure is experienced or is anticipated to be experienced under different conditions such as magnitude and frequency of exposure (Paustenbach, 2002). For the purposes of this study, a non-cancer exposure assessment was completed, due do the significant evidence of the neurotoxic effects of mercury (Hlimi et al, 2012). The population being addressed through this exposure assessment is the First Nations community of Fort Albany, due to their geographic location and the significant fish consumption in their diets (Hlimi et al, 2012). The various uncertainties related to this process will be discussed in later chapters.

The community's dietary intake of northern pike, pickerel, lake sturgeon, longnose carp, and whitefish was used as they are commonly consumed in a traditional diet by community members. Tissue samples were collected and analyzed for the presence of mercury and selenium. Tissue samples were used as other parts are not generally consumed, and due to its lipophilic nature,mercury is known to accumulate in the tissue. The dietary intakes, presented in table 3, were calculated using Canada's Food Guide: First Nations, Inuit and Metis (Health Canada, 2007a).

Using the data obtained from the analysis of the samples, a non-carcinogenic risk assessment was conducted. For this, hazard quotients were calculated for non-carcinogenic compounds using tolerable daily intake or reference dose values from either Health Canada or the USEPA. For non-carcinogenic risk, the intake, also known as the average daily dose was calculated using the following formulae. Note, descriptions of the variables and the values used for the purposes of this research are detailed in Tables 2 and 3. 
Calculate Intake or Average Daily dose $=([\mathrm{C}] *[\mathrm{CR}] *[\mathrm{EF}] *[\mathrm{ED}])$

[BW] $*[\mathrm{AT}]$

Note: Intake values are presented as $\mathrm{mg} / \mathrm{kg}_{b w} /$ day

Table 2. Sources of variables used to calculate the intake or average daily dose

\begin{tabular}{|l|l|}
\hline Variable & Source \\
\hline AT & $\begin{array}{l}\text { The average time is calculated in days using the following guidelines, } \\
\text { Non-carcinogens are calculated using the duration of exposure (relative to } \\
\text { each age group). }\end{array}$ \\
\hline BW & $\begin{array}{l}\text { The body weights are calculated in kg and were categorized by age groups } \\
\text { measurements of the samples which were completed at INSPQ }\end{array}$ \\
\hline C & $\begin{array}{l}\text { The contact rate is calculated in mg/day. It is the amount that is consumed } \\
\text { per category. This value was obtained using consumption data from average } \\
\text { dietary intake weights from Canada's Food Guide: First Nations, Inuit and } \\
\text { Metis }\end{array}$ \\
\hline CR & $\begin{array}{l}\text { The exposure duration is calculated in years using the duration of exposure } \\
\text { that's relative to each age group }\end{array}$ \\
\hline ED & $\begin{array}{l}\text { The effective frequency is calculated in days/year. For the purposes of this } \\
\text { study, a standard of } 365 \text { days/year was used }\end{array}$ \\
\hline EF &
\end{tabular}


Table 3. Values of variables used to calculate the intake or average daily dose

\begin{tabular}{|c|c|c|}
\hline Variable & Category & Value \\
\hline $\begin{array}{l}\text { AT: Average } \\
\text { Time for non- } \\
\text { carcinogenic } \\
\text { exposure }\end{array}$ & All age groups & $\begin{array}{l}\text { The exposure assessment was done for a daily } \\
\text { exposure. A standard value of } \mathbf{1} \text { was used.. }\end{array}$ \\
\hline \multirow{5}{*}{$\begin{array}{l}\text { BW: } \\
\text { Body Weight }\end{array}$} & Age 3 to 6 & 18.60 kg* \\
\hline & Age 6 to 11 & 31.80 kg* \\
\hline & Age 11 to 16 & 56.80 kg* \\
\hline & Age 16 to 21 & 71.60 kg* \\
\hline & Age $21+$ & 80.00 kg* \\
\hline \multirow{5}{*}{$\begin{array}{l}\text { C: } \\
\text { Concentrations }\end{array}$} & Sturgeon & $0.45 \mathrm{mg} / \mathrm{kg}^{* *}$ \\
\hline & Whitefish & $0.23 \mathrm{mg} / \mathrm{kg}^{* *}$ \\
\hline & Pike & $0.5 \mathrm{mg} / \mathrm{kg} * *$ \\
\hline & Pickerel & $0.55 \mathrm{mg} / \mathrm{kg}^{* *}$ \\
\hline & Carp & $0.5 \mathrm{mg} / \mathrm{kg}^{* *}$ \\
\hline $\begin{array}{l}\text { CR: Contact } \\
\text { Rate }\end{array}$ & $\begin{array}{l}\text { All age groups based on } \\
\text { a frequency of } 2 \text { meals } \\
\text { per month }\end{array}$ & $\begin{array}{l}(0.075 \mathrm{~kg} * 2 \text { meals per week }) / 7 \text { days= } \\
\mathbf{0 . 0 2 1 4 3 ~} \mathbf{~ k g} / \text { day } * * *\end{array}$ \\
\hline $\begin{array}{l}\text { ED: Exposure } \\
\text { Duration }\end{array}$ & All age groups & $\begin{array}{l}\text { The exposure assessment was done for a daily } \\
\text { exposure. A standard value of } \mathbf{1} \text { was used as the } \\
\text { averaging time cancels out with the exposure } \\
\text { frequency and the exposure duration. }\end{array}$ \\
\hline $\begin{array}{l}\text { EF: Effective } \\
\text { Frequency }\end{array}$ & All age groups & $\begin{array}{l}\text { The exposure assessment was done for a daily } \\
\text { exposure. A standard value of } \mathbf{1} \text { was used as the } \\
\text { averaging time cancels out with the exposure } \\
\text { frequency and the exposure duration. }\end{array}$ \\
\hline
\end{tabular}

*Values obtained from U.S. Environmental Protection Agency, 2011

**Values obtained from concentrations in Table 4.

*** Average portion size of $0.075 \mathrm{~kg}$ and frequency of 2 meals per month were both obtained from Health Canada, 2007a 
The average daily doses which were acquired from this calculation served as a baseline for the mean consumption rates which were based on age group and community. Using the average daily dose obtained from the calculation, the hazard index (HI) was calculated by comparing the individual contaminants to their associated reference doses (RfD). The RfD value represents the level of daily intake which should not produce an adverse health effect (U.S. Environmental Protection Agency, 1992). The value obtained is then compared to a standardized value of 1 for human health dietary risk assessments. The following formula was used to calculate the hazard index,

$$
\mathrm{HI}=\mathrm{I} / \mathrm{RfD}
$$

Where $I$ is the calculated intake and, $R f D$ is the reference dose. The resultant hazard index value represents the ratio at which no adverse effects are expected, this number was then compared to the value of 1.0 which is conventionally used (U.S. Environmental Protection Agency, 1992).

\subsubsection{Risk Characterization}

During the risk characterization process, the data from the previous steps is integrated to determine the probability of an adverse effect occurring (Paustenbach, 2002). The data obtained provided baseline values to identify what non-cancer risks are for those consuming the fish. The values obtained will be compared to existing guidelines and recommendations for minimizing exposures to contaminants will be provided in the discussion.

\section{$\underline{6.0 \text { Results }}$}

\subsection{Summary of Mercury Concentrations}

For this study, the results have been separated by statistical analysis of the speciesspecific mercury concentrations, as well as the human health risk assessment per species. 
A total of 157 samples were obtained from the Fort Albany River Basin between the study

periods of 2009-2010 and 2011-2012. Of these samples, 146 samples were deemed above the detection limit for mercury [total] which was $<1 \mathrm{nmol} / \mathrm{g}$. Table 4 and Table 5 summarize the values obtained of total $\mathrm{Hg}$ and the descriptive lengths.

Table 4. Total Hg ( $\mu \mathrm{g} / \mathrm{g})$ measured in tissues (wet weight) and presented by species

\begin{tabular}{|l|c|c|c|c|c|c|c|}
\hline Total Hg $(\boldsymbol{\mu g} / \mathbf{g})$ & Mean & Median & SD & Min. & Max. & N & N above detection \\
\hline Carp & 0.50 & 2.3 & 0.32 & 0.10 & 1.38 & 24 & 21 \\
\hline Pickerel & 0.55 & 0.461 & 0.31 & 0.22 & 1.82 & 69 & 69 \\
\hline Pike & 0.50 & 0.441 & 0.22 & 0.10 & 1.16 & 31 & 30 \\
\hline Sturgeon & 0.45 & 0.301 & 0.38 & 0.13 & 1.40 & 20 & 20 \\
\hline Whitefish & 0.23 & 0.05 & 0.16 & 0.10 & 0.50 & 13 & 6 \\
\hline
\end{tabular}

Table 5. Fish length $(\mathrm{cm})$ measured per species sample

\begin{tabular}{|l|c|c|c|c|c|c|}
\hline Species & Mean & Median & Sd & Min. & Max. & N \\
\hline Carp & 38.5 & 41.5 & 4.9 & 24.0 & 49.0 & 24 \\
\hline Pickerel & 38.2 & 38.1 & 8.1 & 24.1 & 68.6 & 69 \\
\hline Pike & 59.0 & 58.5 & 6.1 & 45.7 & 73.7 & 31 \\
\hline Sturgeon & 77.1 & 45.7 & 22.1 & 47.5 & 127.0 & 20 \\
\hline Whitefish & 33.7 & 33.5 & 2.3 & 27.5 & 36.5 & 13 \\
\hline
\end{tabular}

Of the 24 carp species which were acquired, 21 were found to be above the detection level $0.5 \mu \mathrm{g} / \mathrm{g}$ for Total $\mathrm{Hg}$. 30 of the 31 samples for pike were above the detection level. Of the 13 whitefish samples, only 6 were above the detection level. For both pickerel $(n=69)$ and sturgeon $(n=20)$, all samples were above the detection levels. For the statistical analysis, the total $\mathrm{n}$ values were used. 


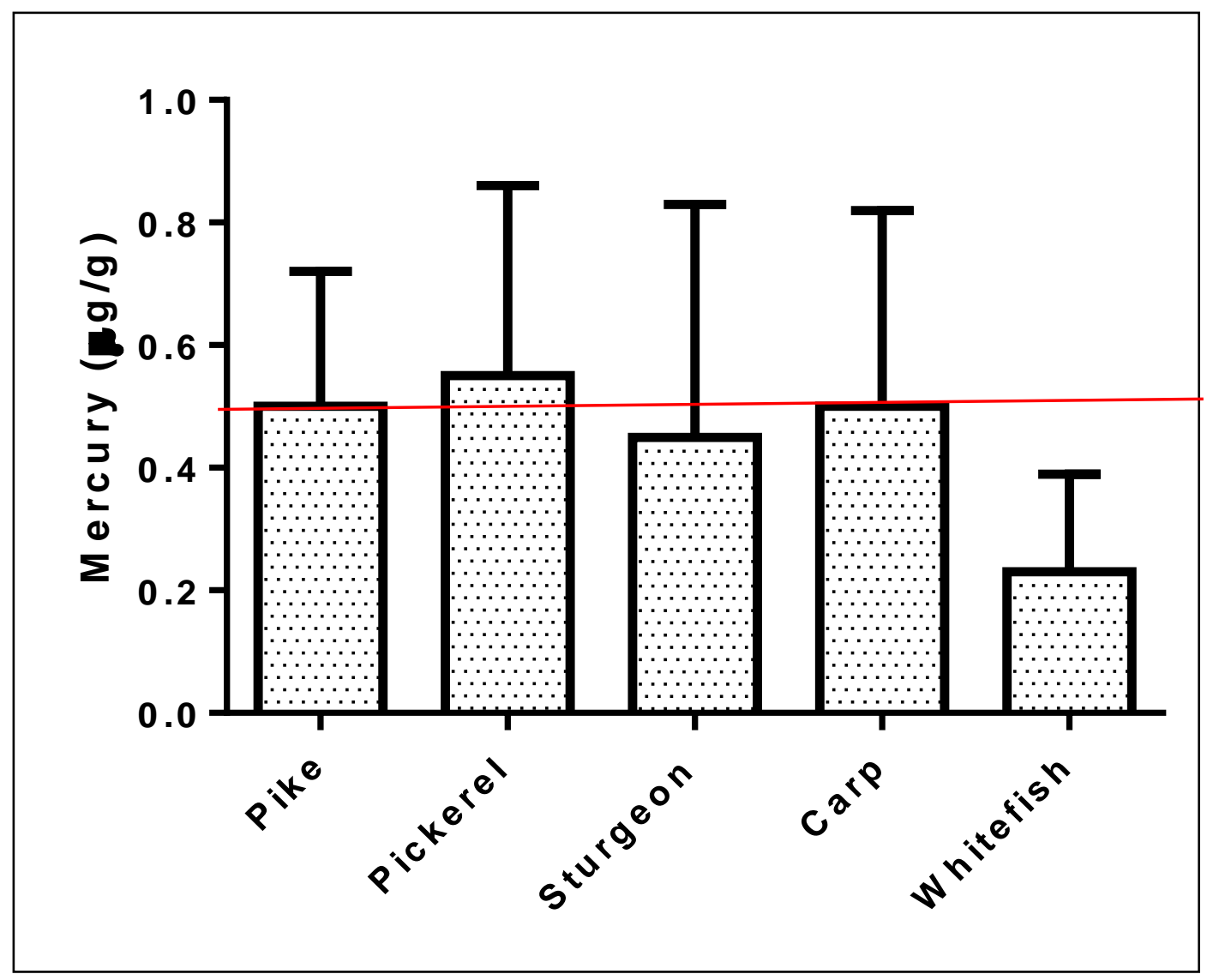

Figure 2. Mean concentrations of Mercury $(\mu \mathrm{g} / \mathrm{g})$ identified per species respective to the 0.5 $\mu \mathrm{g} / \mathrm{g}$ Health Canada guideline

Concentrations for total mercury in $\mathrm{nmol} / \mathrm{g}$ were converted to $\mu \mathrm{g} / \mathrm{g}$ to be comparable to the Health Canada consumption guideline for total mercury in fish tissue of $0.5 \mu \mathrm{g} / \mathrm{g}$ wet weight $(0.5 \mu \mathrm{g} / \mathrm{g}=2.4925 \mathrm{nmol} / \mathrm{g})$. Figure 2 , depicts total mercury concentrations in the various species, related to the $0.5 \mu \mathrm{g} / \mathrm{g}$ guideline displayed in red.

\subsection{Statistical Analysis}

A linear regression was completed to determine the relationship between total $\mathrm{Hg}$ concentrations and length in fish. Where data did not fit a normal distribution, values were logged. The strength of the associations between the independent variable of length, and dependent variable of $\mathrm{Hg}$ concentration, were determined by calculating $\mathrm{R}^{2}$ values. 


\subsubsection{Carp}

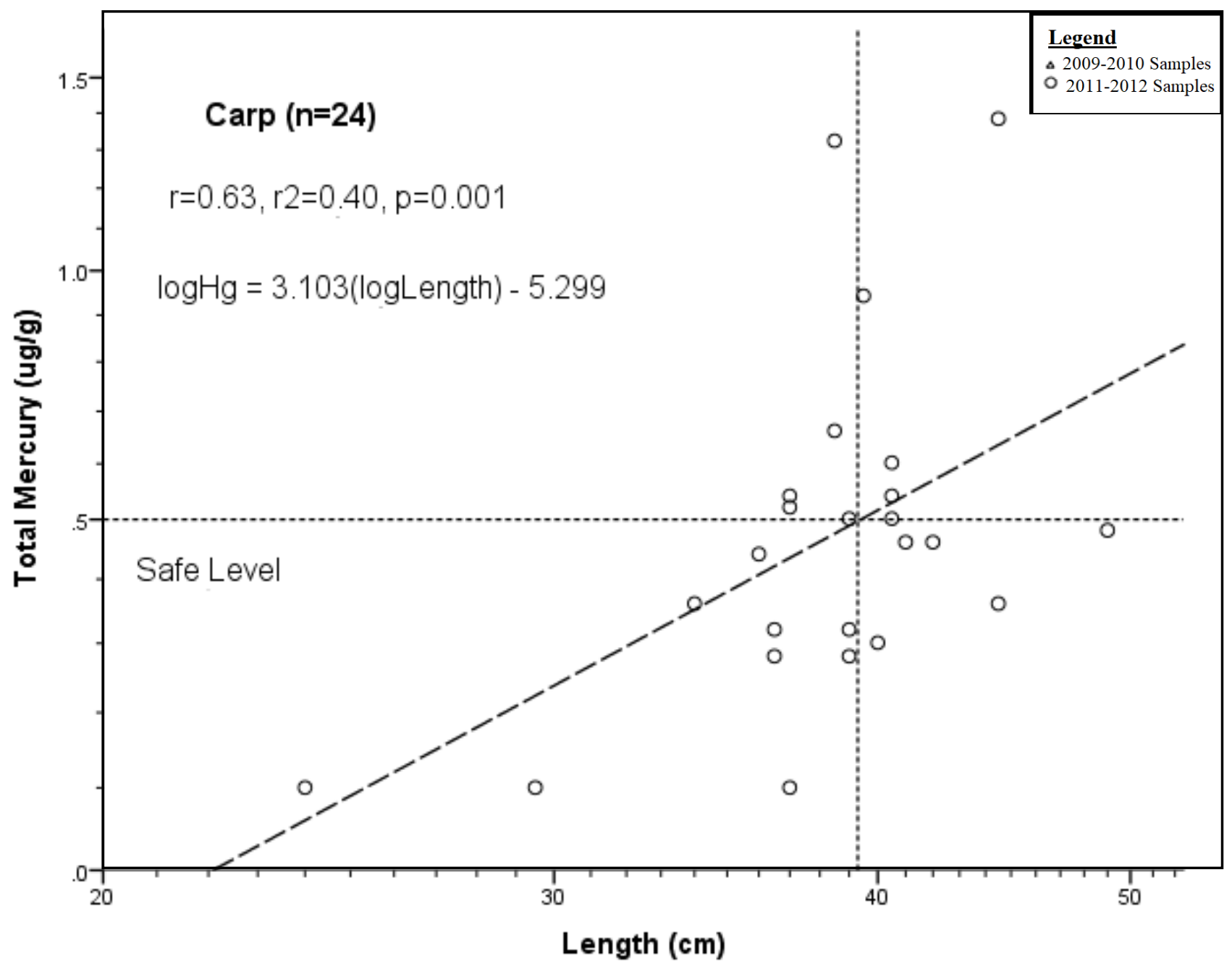

Figure 3. Total $\mathrm{Hg}(\mu \mathrm{g} / \mathrm{g})$ measured in tissues (wet weight) by length $(\mathrm{cm})$ in Carp (20092010 samples) 


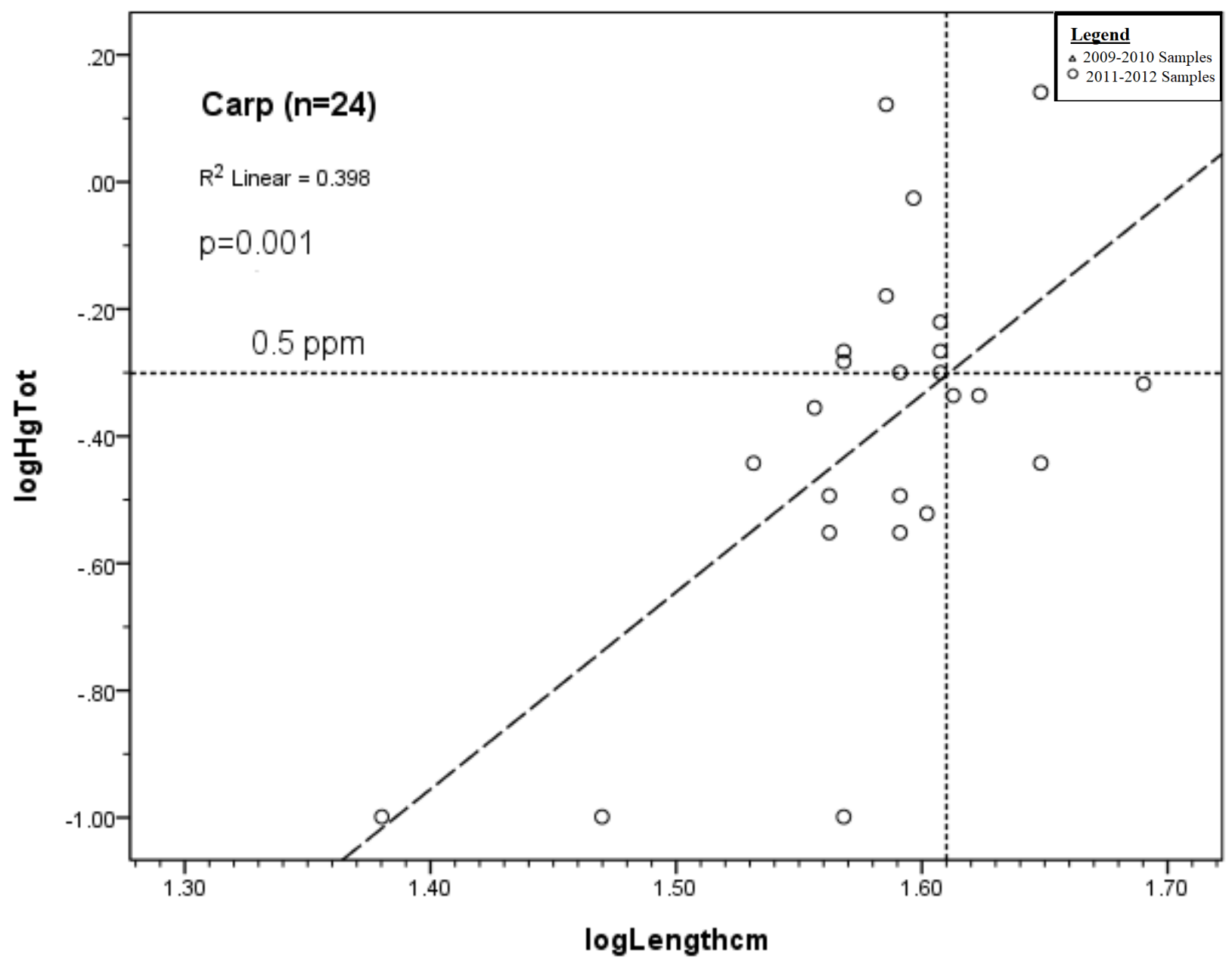

Figure 4. Figure 2. data log-transformed

The levels of total mercury in the carp samples are summarized in Table 4. Based on an $\mathrm{n}=24$, a significant positive relationship between total mercury concentration and body length was found for carp (Figure 3.). In the total carp samples, 16 of 24 samples were below the consumption guideline of $0.5 \mu \mathrm{g} / \mathrm{g}$ (or ppm), with two samples on the border. The total mercury concentration and length were significantly correlated ( $\mathrm{r}=0.63, \mathrm{p}=0001$; Fig 3.). In addition, linear regression analysis revealed that $40 \%$ of the variation in total mercury was attributable to variation in body length (Figures 3. \& 4.). 


\subsubsection{Pickerel}

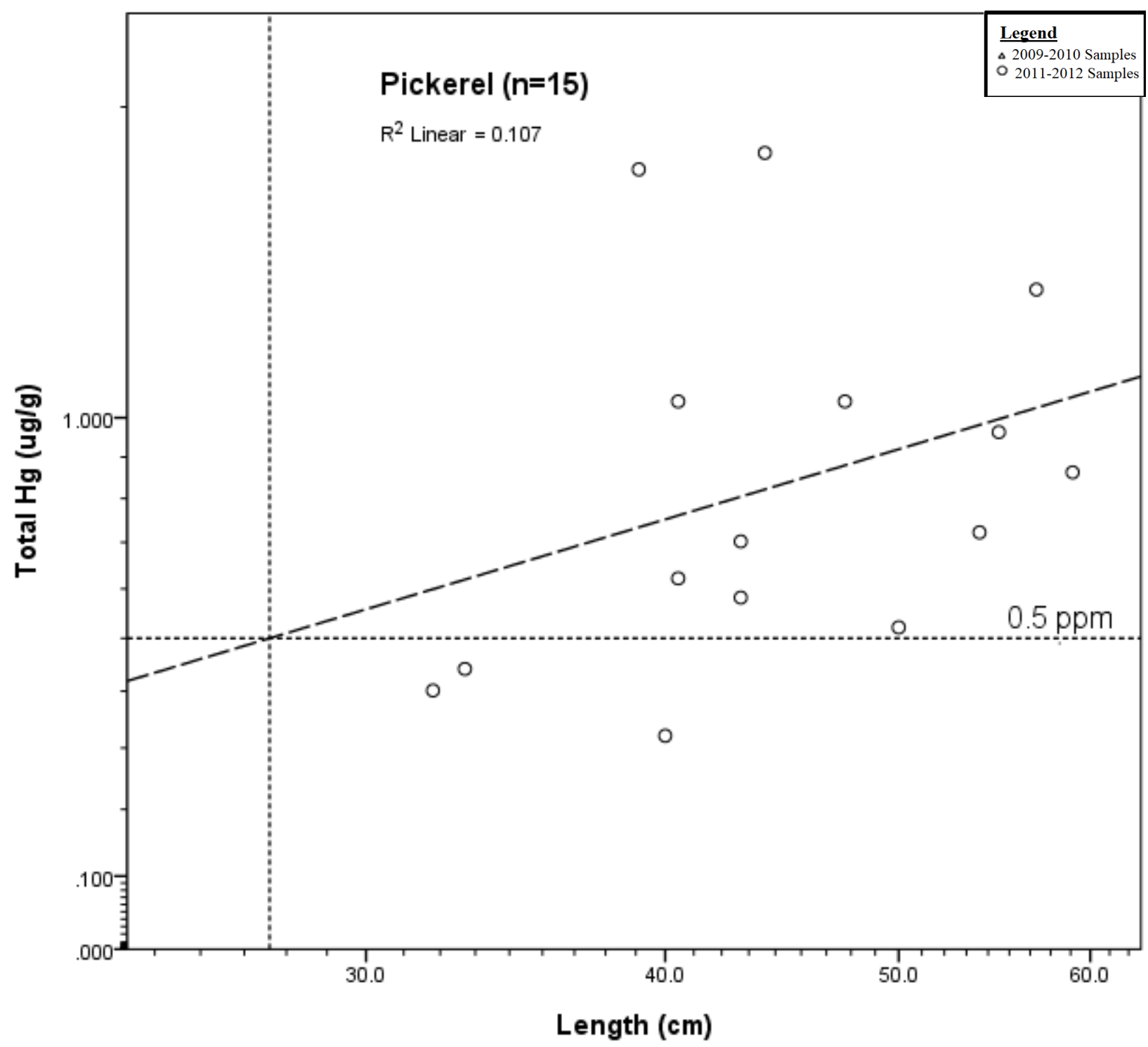

Figure 5. Total $\mathrm{Hg}(\mu \mathrm{g} / \mathrm{g})$ measured in tissues (wet weight) by length $(\mathrm{cm})$ in Pickerel (20092010) 


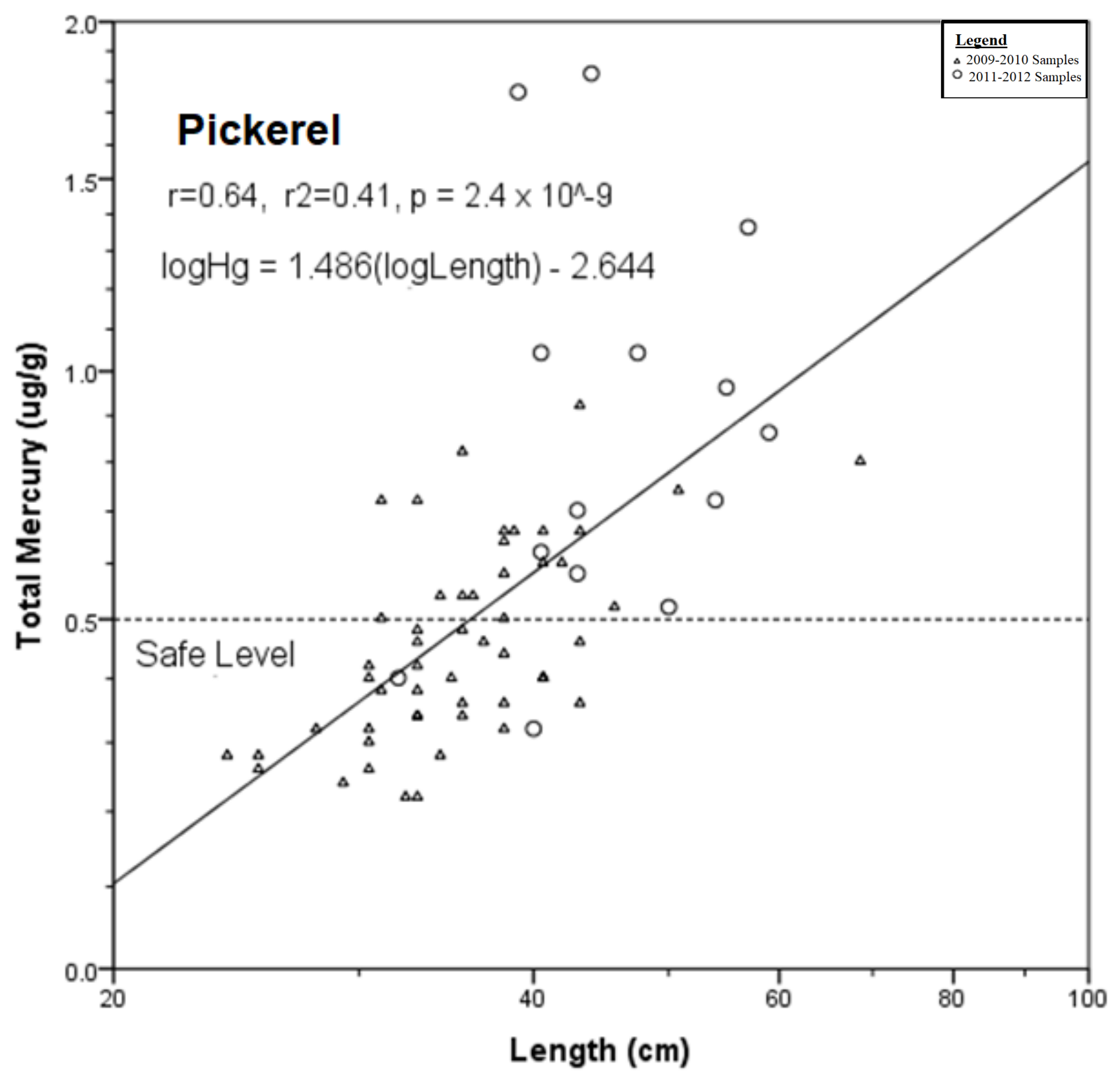

Figure 6. Total $\mathrm{Hg}(\mu \mathrm{g} / \mathrm{g})$ measured in tissues (wet weight) by length $(\mathrm{cm})$ in Pickerel (Total 2009-2010 and 2011-2012)

The levels of total mercury in the pickerel samples are summarized in Table 4. In the 2009-2010 pickerel samples (Figure 5.), 3 of 15 samples were below the consumption guideline of $0.5 \mu \mathrm{g} / \mathrm{g}$ (or ppm). In the total pickerel samples (Figure 5.), 34 of 69 samples were below the consumption guideline of $0.5 \mu \mathrm{g} / \mathrm{g}$ (or ppm), with two being at the border. For pickerel (Figure 5.), note the lack of a relationship between total mercury and body length. Nevertheless, it should 
be noted that only 3 of 15 samples were below the consumption guideline of $0.5 \mu \mathrm{g} / \mathrm{g}$ (or ppm). In Figure 6., the 2009-2010 ( $\mathrm{n}=15)$ was combined with the 2011-2012 data $(\mathrm{n}=54)$. Based on a total $n=69$ (Figure 6), a significantly positive relationship between total mercury concentration and body length was found for pickerel. The total mercury concentration and length were significantly correlated $\left(\mathrm{r}=0.64, \mathrm{p}=2.4 \times 10^{-9}\right)$. In addition, the linear regression analysis revealed that $41 \%$ of the variation in total mercury was attributed to variation in body length. This relationship is not as strong in figure 5., with only $11 \%$ of the variation in total mercury being attributed to variation in body length. This may be due to the low sample size of $n=15$ ). 


\subsubsection{Pike}

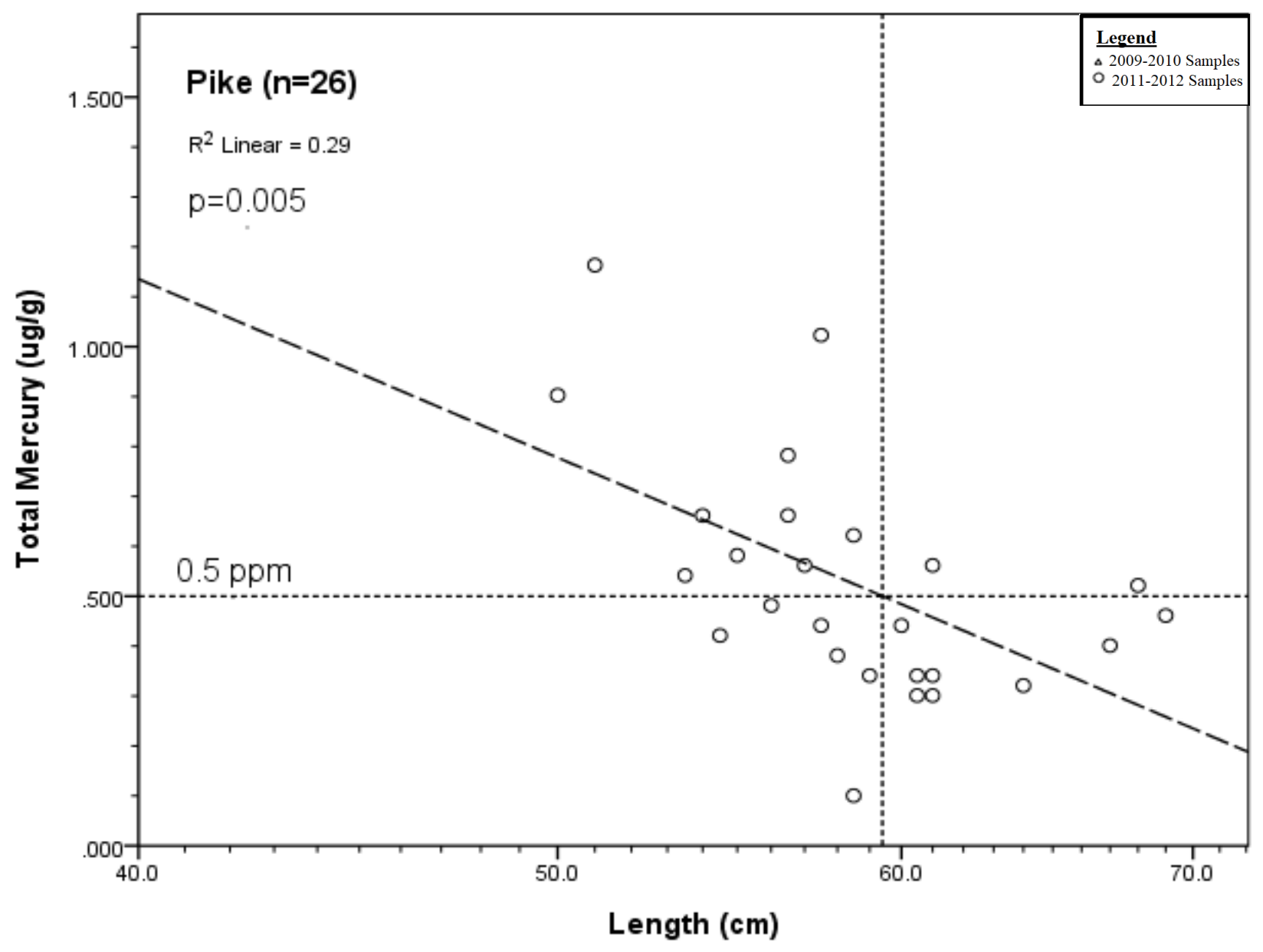

Figure 7. Total $\mathrm{Hg}(\mu \mathrm{g} / \mathrm{g})$ measured in tissues (wet weight) by length (cm) in Pike (20092010) 


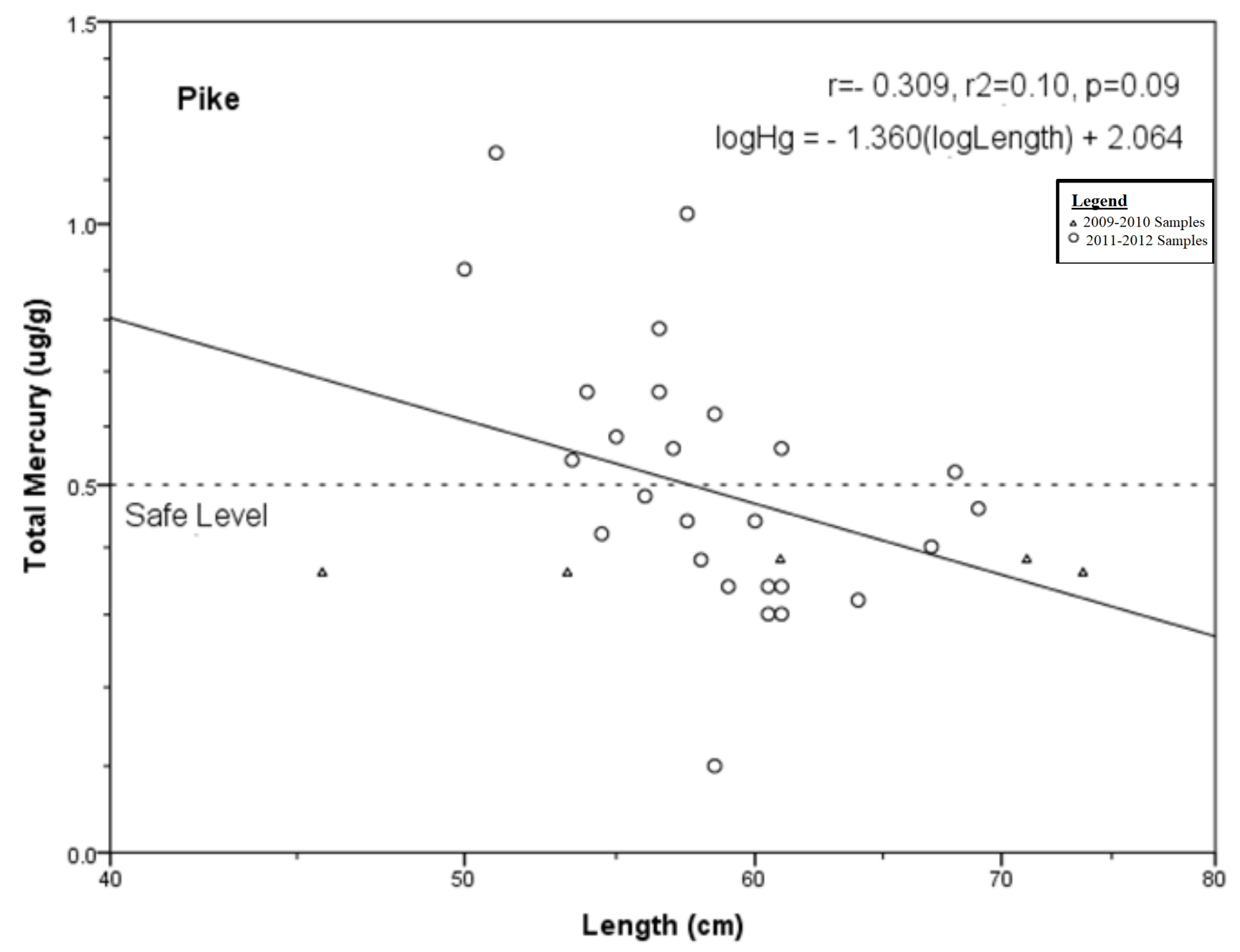

Figure 8. Total $\mathrm{Hg}(\mu \mathrm{g} / \mathrm{g})$ measured in tissues (wet weight) by length $(\mathrm{cm})$ in Pike (Total 2009-2010 and 2011-2012)

The levels of total mercury in the pike samples are summarized in Table 4. In the 20092010 pike samples (Figure 7.), 14 of 26 samples were below the consumption guideline of 0.5 $\mu \mathrm{g} / \mathrm{g}$ (or ppm). In the total pike samples (Table 4), 18 of 31 samples were below the consumption guideline of $0.5 \mu \mathrm{g} / \mathrm{g}$ (or ppm). By contrast to the other species, in pike, a significant negative relationship was noted between total mercury concentration and body length (Figure 7. and 8.). This means that in the entirety of the samples, as length increased, the concentrations of mercury decreased. In Figure 7, where $n=26,29 \%$ of the variation in total 
mercury was attributable to variation in body length in pike. This relationship is statistically significant with $\mathrm{p}=0.005$. In 2010-2011, 5 additional samples were added and resulted in a $\mathrm{p}=0.09$, although the trend was still apparent (Figure 8.). Including the samples evidentially changed the strength of the relationship with $10 \%$ of the variation in total mercury being attributable to variation in body length in pike. However, the 5 samples included were linear in their mercury concentrations, identifying a potential anomaly in the data. Possible causes for this relationship will be discussed later in the discussion chapter. 


\subsubsection{Sturgeon}

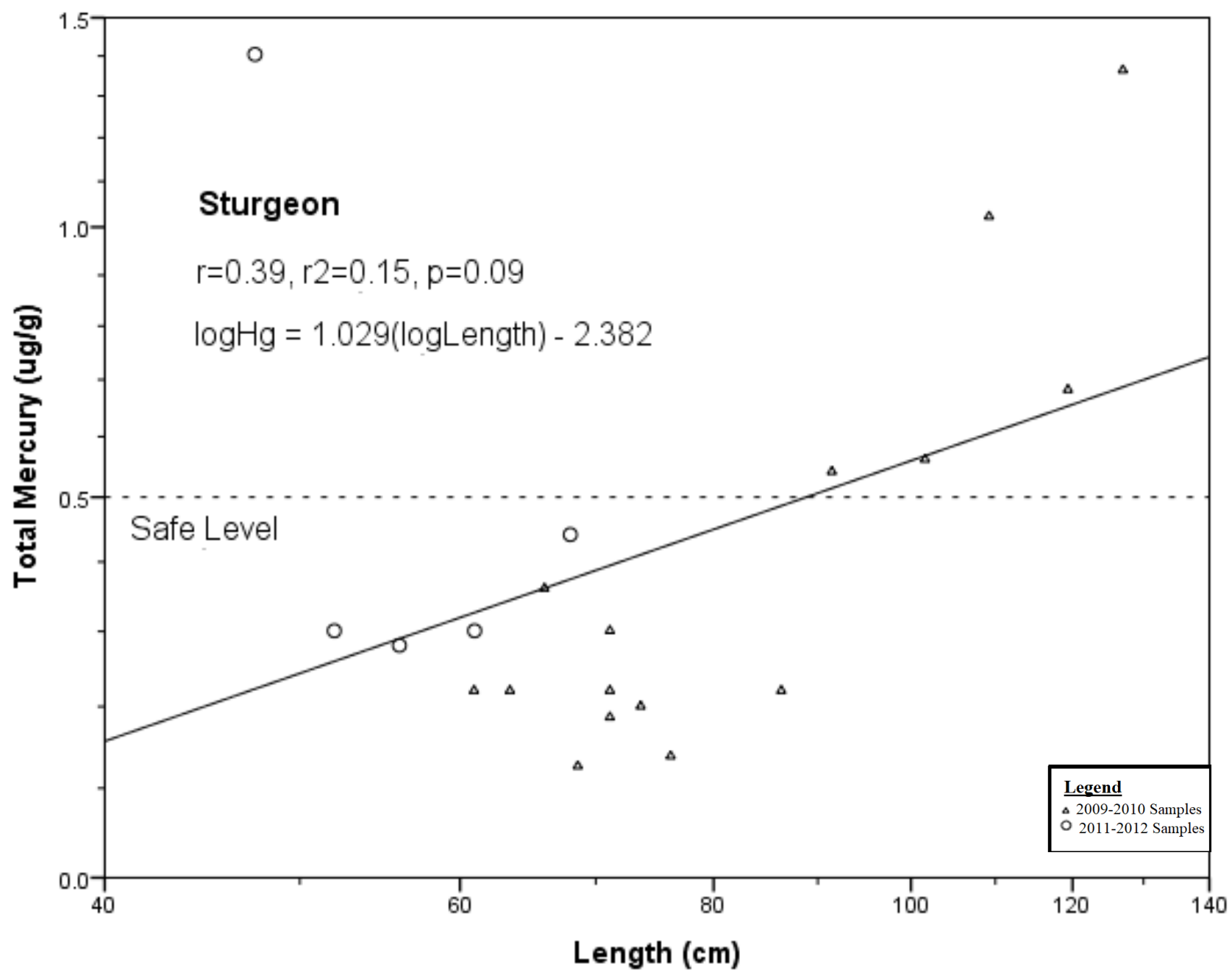

Figure 9. Total $\mathrm{Hg}(\mu \mathrm{g} / \mathrm{g})$ measured in tissues (wet weight) by length $(\mathrm{cm})$ in Sturgeon (Total 2009-2010 and 2011-2012)

The levels of total mercury in the sturgeon samples are summarized in Table 4. In the total sturgeon samples (Figure 9.), 14 of 20 samples were below the consumption guideline of 0.5 $\mu \mathrm{g} / \mathrm{g}$ (or ppm). Based on an $\mathrm{n}=20$, the relationship between total mercury concentration and body length was not significant for sturgeon (Figure 9.). The total mercury concentration and length were not correlated $(r=0.39, \mathrm{p}=0.09$; Fig 9). In addition, linear regression analysis revealed that only $15 \%$ of the variation in total mercury was attributable to variation in body length. 


\subsubsection{Whitefish}

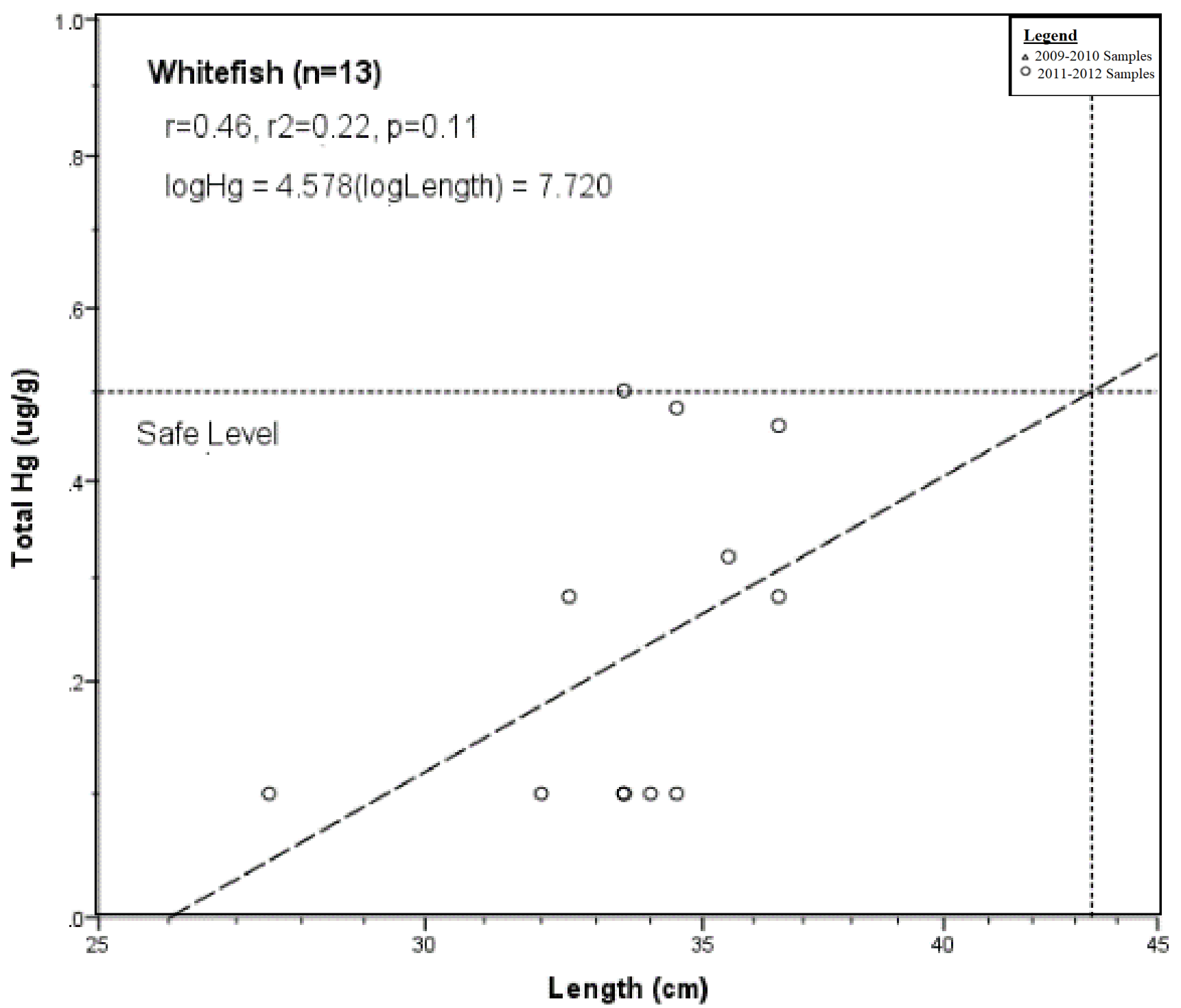

Figure 10. Total $\mathrm{Hg}(\mu \mathrm{g} / \mathrm{g})$ measured in tissues (wet weight) by length $(\mathrm{cm})$ in whitefish (2009-2010)

The levels of total mercury in the whitefish samples are summarized in Table 4. By contrast, for whitefish, 12 of 13 samples were below the consumption guideline of $0.5 \mu \mathrm{g} / \mathrm{g}$ (or ppm), with one sample on the border. Based on $n=13$, the relationship between total mercury concentration and body length was not significant for whitefish. The total mercury concentration and length were not correlated ( $\mathrm{r}=0.46, \mathrm{p}=0.11$; Figure 10.). In addition, linear regression 
analysis revealed that only $22 \%$ of the variation in total mercury was attributable to variation in body length.

\subsection{Summary of Selenium Concentrations}

For this paper, the results have been separated by statistical analysis of the speciesspecific Selenium concentrations. Concentrations for selenium $(\mu \mathrm{g} / \mathrm{g})$ were measured in tissues (wet weight). Descriptive statistics were generated utilizing wet weight data. Levels below the DL were imputed as $1 / 2$ the DL, when appropriate. Linear regression analysis was used to examine the relationship between body weight and total selenium for species, when sample sizes were adequate. A total of 157 samples were obtained from the Fort Albany River Basin between the study periods of 2009-2010 and 2011-2012. Table 6, summarizes the descriptive of Selenium and the descriptive lengths respectively.

Table 6. Selenium concentrations $(\mu \mathrm{g} / \mathrm{g})$ measured in tissues (wet weight) and presented by species

\begin{tabular}{|l|c|c|c|c|c|c|c|}
\hline Se $(\boldsymbol{\mu g} / \mathrm{g})$ & Mean & Median & SD & Min. & Max. & N & $\begin{array}{c}\text { N above } \\
\text { detection }\end{array}$ \\
\hline Carp & 0.30 & 0.28 & 0.12 & 0.13 & 0.66 & 24 & 24 \\
\hline Pickerel & 0.39 & 0.28 & 0.32 & 0.14 & 1.10 & 15 & 15 \\
\hline Pike & 0.26 & 0.255 & 0.12 & 0.10 & 0.67 & 28 & 28 \\
\hline Sturgeon & 0.19 & 0.18 & 0.04 & 0.13 & 0.24 & 9 & 9 \\
\hline Whitefish & 0.61 & 0.49 & 0.27 & 0.33 & 1.20 & 13 & 13 \\
\hline
\end{tabular}




\subsubsection{Carp}

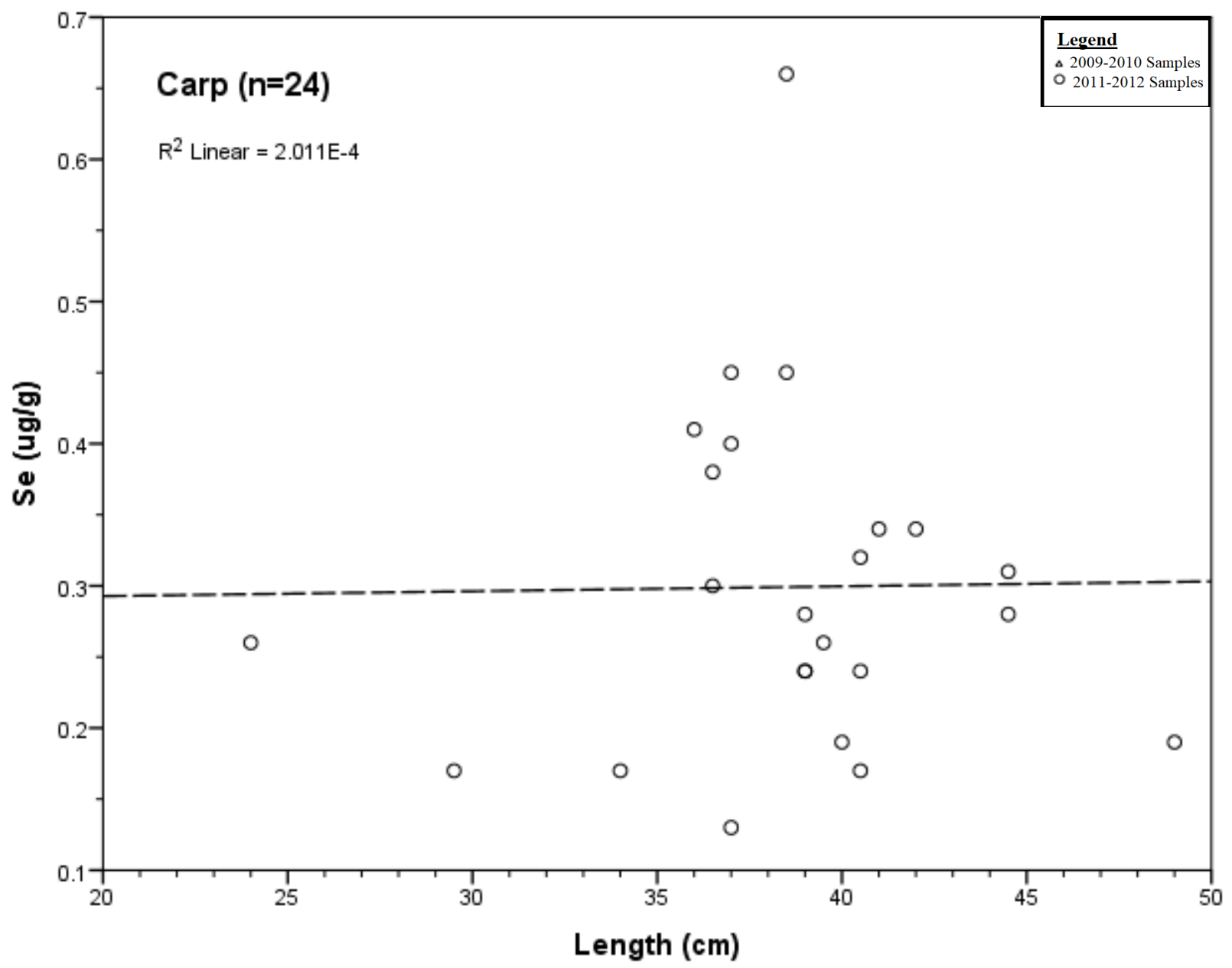

Figure 11. Se ( $\mu \mathrm{g} / \mathrm{g})$ measured in tissues (wet weight) by length $(\mathrm{cm})$ in Carp (2009-2010)

The levels of Selenium $(\mu \mathrm{g} / \mathrm{g})$ in the 2009-2010 samples Carp samples are summarized in

Table 11. Based on an $n=24$, a relationship between total mercury concentration and body length was not evident in these samples for carp (Figures 3. \& 4.). The selenium concentration and length were not significantly correlated (Figure 11.). In addition, linear regression analysis revealed an $\mathrm{R}^{2}$ value of 0.0002011 meaning only $0.02 \%$ of the variation in total selenium was attributable to variation in body length. 


\subsubsection{Pickerel}

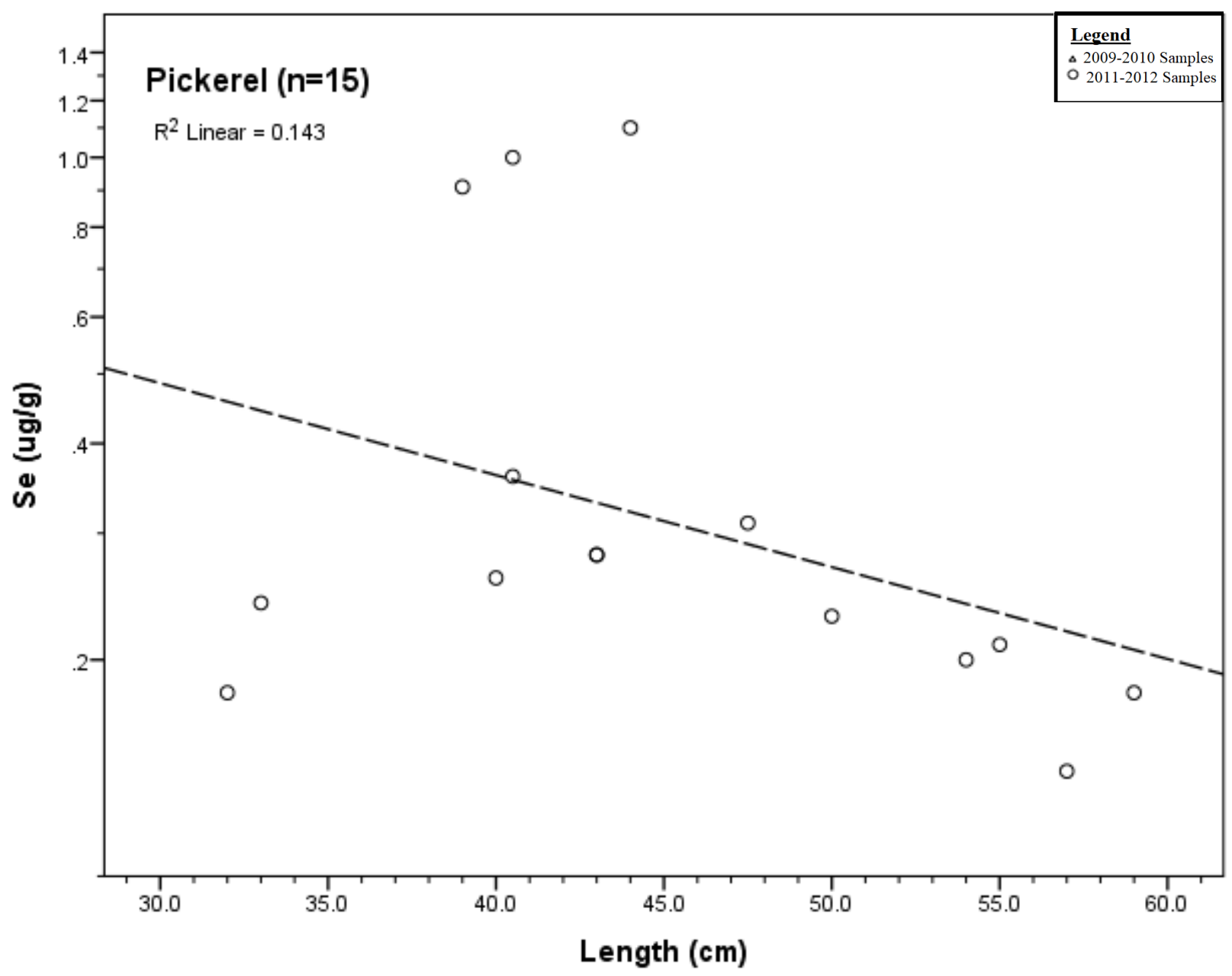

Figure 12. $\mathrm{Se}(\mu \mathrm{g} / \mathrm{g})$ measured in tissues (wet weight) by length $(\mathrm{cm})$ in Pickerel (2009-2010)

The levels of selenium $(\mu \mathrm{g} / \mathrm{g})$ in the 2009-2010 pickerel samples are summarized in Table

6. In the 2009-2010 pickerel samples (Figure 12.), some of the highest selenium concentrations were found up to $1.2 \mu \mathrm{g} / \mathrm{g}$. For pickerel (Figure 12.), there is an observable relationship between selenium concentration and body length. The linear regression analysis revealed that $14 \%$ of the variation in selenium concentrations were attributed to variation in body length. This may be due to the low sample size of $n=15)$. 


\subsubsection{Pike}

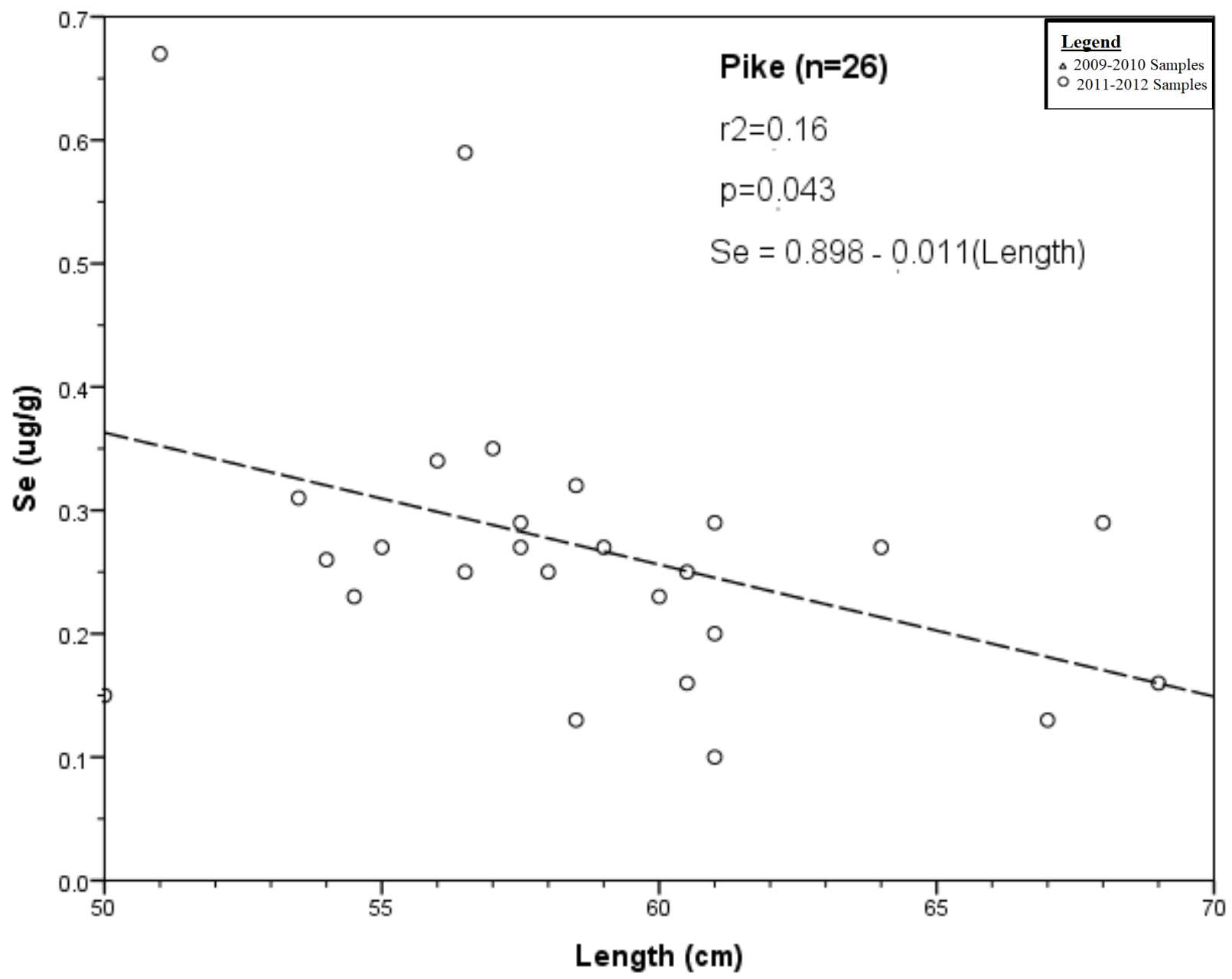

Figure 13. Se $(\mu \mathrm{g} / \mathrm{g})$ measured in tissues (wet weight) by length $(\mathrm{cm})$ in Pike (2009-2010)

The levels of Selenium ( $\mu \mathrm{g} / \mathrm{g})$ in the 2009-2010 Pike samples are summarized in Table 6.

In the 2009-2010 pike samples (Figure 13.), 14 of 26 samples were below the consumption guideline of $0.5 \mu \mathrm{g} / \mathrm{g}$ (or ppm). Similar to the relationship observed in mercury concentrations (Figure $7 \& 8$.), by contrast to the other species, in pike, a negative relationship was noted between selenium concentration and body length (Figure 13.). This would suggest that in the entirety of the samples, as length increased, the concentrations of mercury decreased. In figure 13 , where $n=26,16 \%$ of the variation in selenium was attributable to variation in body length in 
pike. This relationship is statistically significant with $\mathrm{p}=0.043$. Possible causes for this relationship will be discussed later in the discussion chapter. 


\subsubsection{Sturgeon}

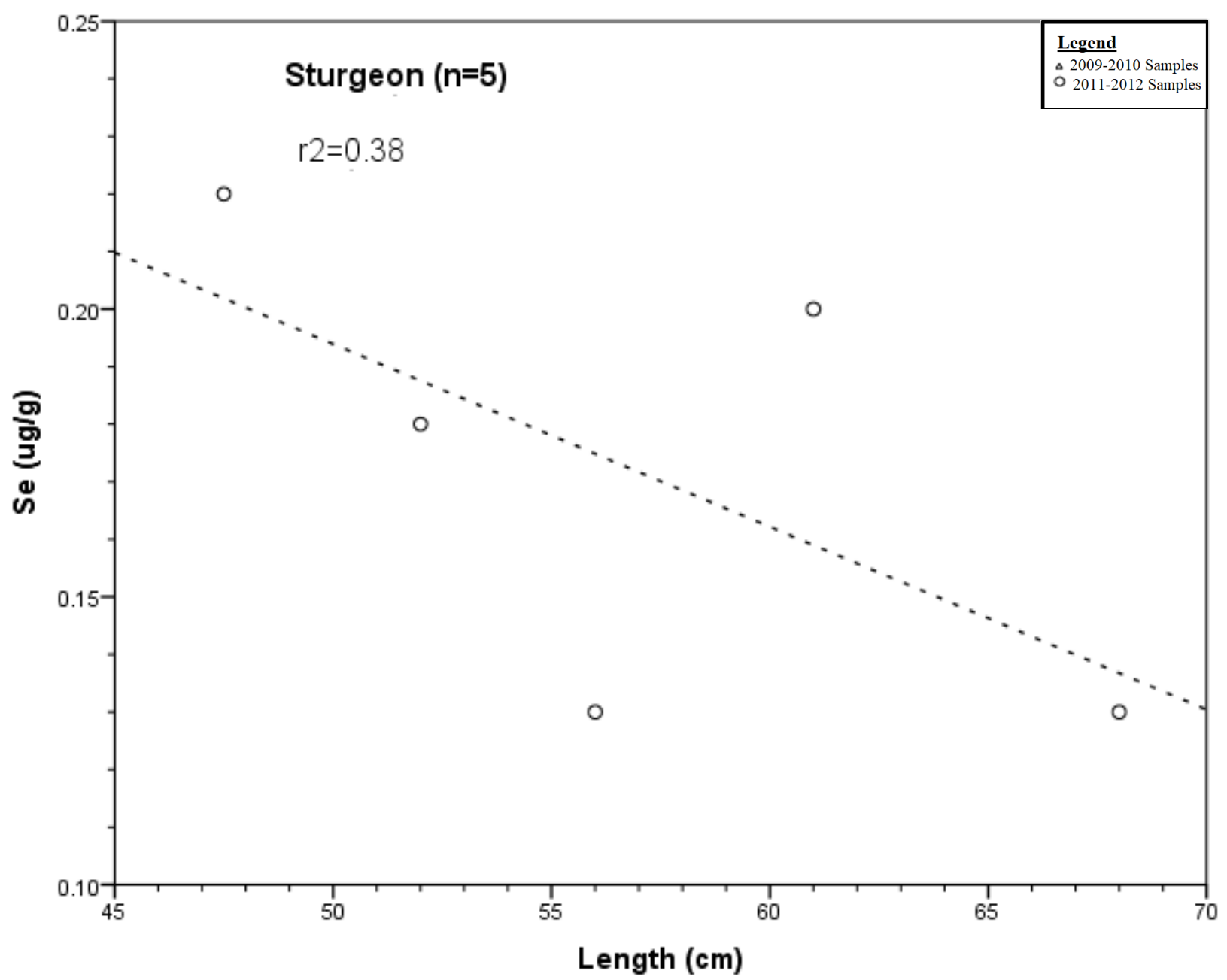

Figure 14. $\mathrm{Se}(\mu \mathrm{g} / \mathrm{g})$ measured in tissues (wet weight) measured in length $(\mathrm{cm})$ in Sturgeon (2009-2010)

The levels of selenium $(\mu \mathrm{g} / \mathrm{g})$ in the 2009-2010 sturgeon samples are summarized in Table 6. In the total sturgeon samples (Figure 14.), 14 of 20 samples were in lower concentrations observed below $0.22 \mu \mathrm{g} / \mathrm{g}$. In the linear regression analysis revealed that $38 \%$ of the variation in selenium was attributable to variation in body length. However, due to the low sample size $(\mathrm{n}=5)$, this may not be a significant relationship. 


\subsubsection{Whitefish}

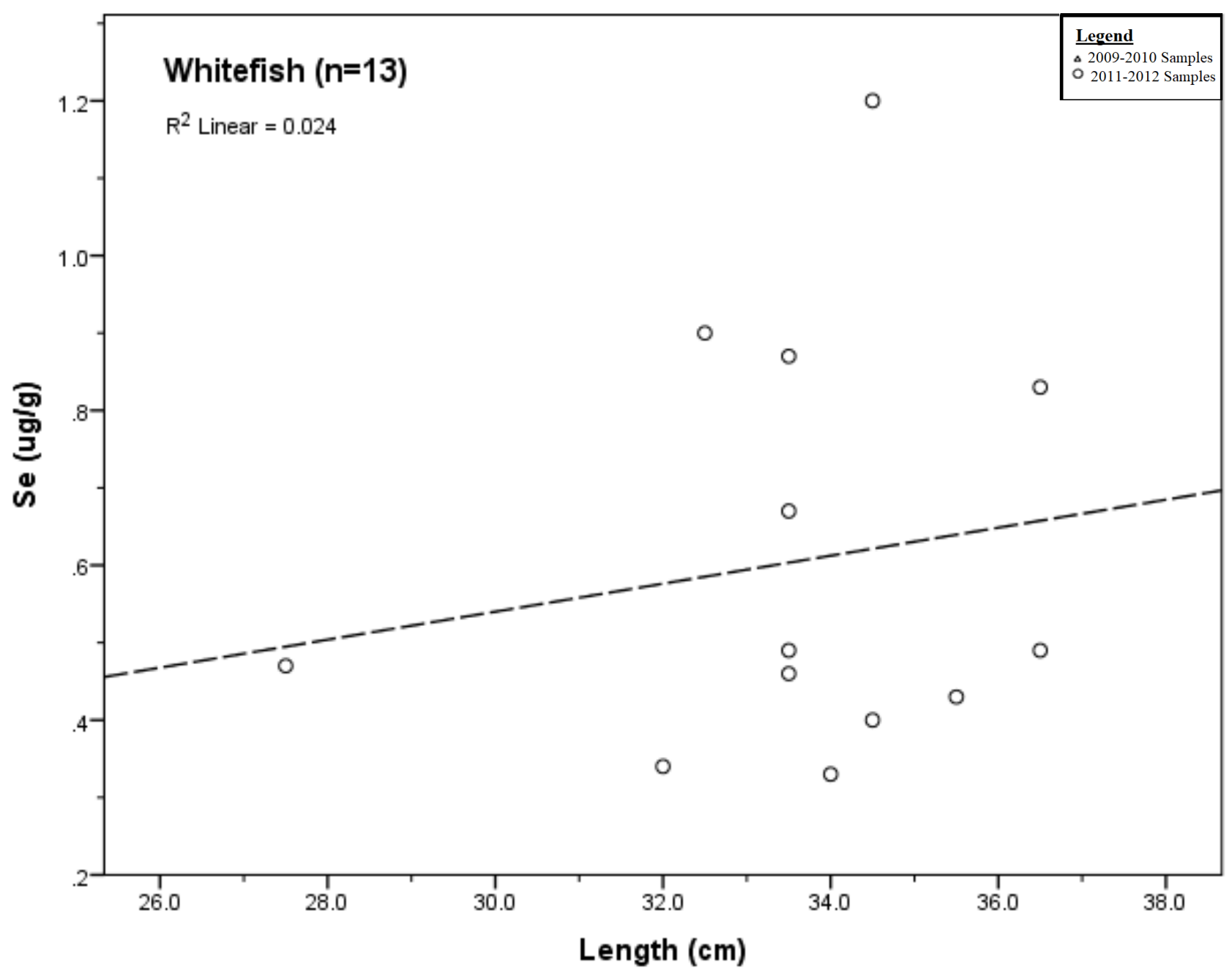

Figure 15. Se( $\mu \mathrm{g} / \mathrm{g})$ measured in tissues (wet weight) by length $(\mathrm{cm})$ in Whitefish (20092010)

The levels of selenium $(\mu \mathrm{g} / \mathrm{g})$ in the 2009-2010 whitefish samples are summarized in Table 6. By contrast, for whitefish, higher concentrations up to $1.2 \mu \mathrm{g} / \mathrm{g}$ were observed (Figure 15.). Based on $n=14$, the observed relationship between total mercury concentration and body length was not very significant for whitefish. In addition, linear regression analysis revealed that only $2 \%$ of the variation in selenium was attributable to variation in body length. 


\subsection{Human Health Exposure Assessment}

After completing the statistical analysis of the mercury levels in the various species, a human health exposure assessment was completed as a part of the risk assessment process.

Mercury concentrations from Table 4 were used and the daily intakes were calculated using the values in Table 3.

Table 7. Summary of the intake and hazard index calculations for all 5 species

\begin{tabular}{|c|c|c|c|}
\hline Species & Age Group & $\begin{array}{l}\text { Intake } \\
\text { (mg/kgbw/day) }\end{array}$ & Hazard Index \\
\hline \multicolumn{4}{|l|}{ Carp } \\
\hline & 3 to 6 & 0.0006 & 2.88 \\
\hline & 6 to 11 & 0.0003 & 1.68 \\
\hline & 11 to 16 & 0.0002 & 0.40 \\
\hline & 16 to 21 & 0.0001 & 0.32 \\
\hline & $21+$ & 0.0001 & 0.28 \\
\hline \multicolumn{4}{|l|}{ Pickerel } \\
\hline & 3 to 6 & 0.0006 & 3.17 \\
\hline & 6 to 11 & 0.0004 & 1.85 \\
\hline & 11 to 16 & 0.0002 & 0.44 \\
\hline & 16 to 21 & 0.0002 & 0.35 \\
\hline & $21+$ & 0.0001 & 0.31 \\
\hline \multicolumn{4}{|l|}{ Pike } \\
\hline & 3 to 6 & 0.0006 & 2.88 \\
\hline & 6 to 11 & 0.0003 & 1.68 \\
\hline & 11 to 16 & 0.0002 & 0.40 \\
\hline & 16 to 21 & 0.0001 & 0.32 \\
\hline & $21+$ & 0.0001 & 0.28 \\
\hline \multicolumn{4}{|c|}{ Sturgeon } \\
\hline & 3 to 6 & 0.0005 & 2.59 \\
\hline & 6 to 11 & 0.0003 & 1.52 \\
\hline & 11 to 16 & 0.0002 & 0.36 \\
\hline & 16 to 21 & 0.0001 & 0.29 \\
\hline & $21+$ & 0.0001 & 0.26 \\
\hline \multicolumn{4}{|c|}{ Whitefish } \\
\hline & 3 to 6 & 0.0003 & 1.32 \\
\hline & 6 to 11 & 0.0002 & 0.77 \\
\hline & 11 to 16 & 0.0001 & 0.18 \\
\hline & 16 to 21 & 0.0001 & 0.15 \\
\hline & $21+$ & 0.0001 & 0.13 \\
\hline
\end{tabular}


From the human health risk assessment values in Table 7, the daily intake rate $\left(\mathrm{mg} / \mathrm{kg}_{\mathrm{bw}} /\right.$ day) for methylmercury was compared it to the reference dose values defined as per the age groups. Through the results, we determined the variances between intakes based on age groups and species. The intake rates for the 0 to 10 age group are higher for all species due to various factors relating to intake such as the decreased body weights and frequency of consumption. These factors will be further analyzed in the discussion chapter.

Compared to a hazard index value for 1.0, we determined to what extent the intakes exceeded the limits. The hazard index was highest for people in the age group between 3 to 6 , who consumed Pickerel (3.17), Pike (2.88), Carp (2.88) and Sturgeon (2.59). The lowest HI was for Whitefish (1.32). Total mercury intakes in all species, exceeded the Health Canada tolerable daily intake of $0.0002 \mathrm{mg} / \mathrm{kg}_{\mathrm{bw}} / \mathrm{day}$ (Health Canada, 2010)

For age groups between 6 to 11, the hazard index value of 1 was exceeded for Pickerel (1.85), Pike (1.68), Carp (1.68) and Sturgeon (1.52). Whitefish (0.78) was the only species assessed which did not exceed the hazard index value. Total mercury intakes in all species, excluding whitefish, exceeded Health Canada tolerable daily intake of $0.0002 \mathrm{mg} / \mathrm{kg}_{\mathrm{bw}} / \mathrm{day}$ for children under 13 (Health Canada, 2010).

For age groups between 11 to 16 , the hazard index was not exceeded for any of the species. All species included, Pickerel (0.44), Pike (0.40), Carp (0.40), Sturgeon (0.36) and Whitefish (0.18). The daily intakes were all higher for all species, excluding white fish, and exceeded the Health Canada tolerable daily intake of $0.0002 \mathrm{mg} / \mathrm{kg}_{\mathrm{bw}} / \mathrm{day}$ for children under 13 (Health Canada, 2010). The hazard index and intakes were much lower for this age group versus all others, where possible variances can be attributed to differences in bodyweight. 
For age groups between 16 to 21 , the hazard index was not exceeded for any of the species. All species included, Pickerel (0.35), Pike (0.32), Carp (0.32), Sturgeon (0.29) and Whitefish (0.15). The daily intakes were lower for all species compared to the Health Canada tolerable daily intake of $0.00047 \mathrm{mg} / \mathrm{kg}_{\mathrm{bw}} /$ day for adults (Health Canada, 2010). The hazard index and intakes were much lower for this age group versus all others, where possible variances can be attributed to differences in bodyweight.

Lastly, for age groups between 11 to 16 , the hazard index was not exceeded any of the species. All species including, Pickerel (0.31), Pike (0.28), Carp (0.32), Sturgeon (0.26) and Whitefish (0.13). The daily intakes were all lower for all species compared to the Health Canada tolerable daily intake of $0.00047 \mathrm{mg} / \mathrm{kg}_{\mathrm{bw}} /$ day for adults (Health Canada, 2010). The hazard index and intakes were lowest for this age group versus all others, where possible variances can be attributed to differences in bodyweight.

\section{$\underline{\text { 7.0 Discussion }}$}

Kuhnlein and Chan (2000), suggest that mercury is one of the major toxic metal contaminants in northern regions of North America. These toxic metals are often identified in food and can lead to exposure among subsistence First Nations peoples (Kuhnlein \& Chan, 2000). The assessment of mercury in fish species that are readily consumed by First Nations communities such as Fort Albany First Nation are crucial for monitoring the well-being of the population and the species within the Albany River. In humans, and species present in the aquatic ecosystems, methylmercury is of great concern due to the ability to bioaccumulate and biomagnify in aquatic systems, along with its potential to be absorbed and distributed to tissues (Harley et al, 2015; Wolfe, Schwarzbach, \& Sulaiman, 1998). A standard from the Health Canada consumption guideline for total mercury in fish tissue of $0.5 \mu \mathrm{g} / \mathrm{g}$ wet weight 
$(0.5 \mu \mathrm{g} / \mathrm{g}=2.4925 \mathrm{nmol} / \mathrm{g})$ was used respectively. The measure of total mercury is used as a standard during the statistical analysis and the human health risk assessment as the general consensus with Health Canada is that the specific measure of methylmercury is more expensive, and, in the aquatic environment, mercury is assumed to have been methylated and taken on its more toxic form of methylmercury (Health Canada, 2007b). The presence of mercury over the detection limit of $<1 \mathrm{nmol} / \mathrm{g}$, in 146 of the samples provided us with further insight for the potential risk of exposure amongst the population of Fort Albany First Nation.

\subsection{Statistical Analysis}

The statistical analysis between length and total mercury concentrations was important to analyze as it provides insight into whether or not larger fish have high levels of mercury. Based on the data obtained, recommendations can be made for future consumption guidelines and provide evidence towards understanding the variances in mercury concentrations within and between species.

The relationship between length and concentration of total mercury was observed to be a positive relationship in most of the species analyzed. Carp, pickerel, sturgeon/carp, and whitefish, all indicated positive relationships between the increasing length of fish and the increasing concentration of total mercury in the tissue. The two-species showing statistical significance of these positive relationships were $\operatorname{carp}(n=24 ; p=0.001)$ and pickerel $(n=69 ; p=2.4$ $\mathrm{x} 10^{-9}$ ). This indicates that there is a significant relationship between length and mercury concentration for these samples. Although no significant relationship was noted between total mercury concentration and length for pickerel, it is important to note that only 3 of the 15 samples were below the consumption guideline for total mercury. It would be particularly 
important to collect more pickerel specimens with a length $<35 \mathrm{cms}$ to see if the fish in this range are fit for consumption.

The relationship between length $(\mathrm{cm})$ and total mercury was not statistically significant for sturgeon $(n=20, p=0.09)$ and whitefish $(n=13, p=0.11)$. This indicates that any variation in the data could be by chance alone. 12 of the 13 whitefish sampled were $<0.5 \mu \mathrm{g} / \mathrm{g}$ total mercury, with the $13^{\text {th }}$ sample at the borderline.

The relationship between length and concentration of total mercury was observed to be a negative relationship in Pike. The relationship was statistically significant for Pike $(n=26$, $\mathrm{p}=0.005$ ) when only the 2009-2010 samples were included. However, when the 2011-2014 data was included, the relationship was not statistically significant $(n=29, p=0.09)$. However, the 5 samples included were linear in their mercury concentrations, identifying a potential anomaly in the data. As all five samples are between the range of $0.3 \mu \mathrm{g} / \mathrm{g}$ and $0.4 \mu \mathrm{g} / \mathrm{g}$, the data could potentially be impacted by the detection limits set. As the 5 points are all very linear, it reduces the statistical significance of the relationship. However, a further analysis regarding the statistically significant relationship of the samples between 2009-2010 was analyzed further to determine probable causes.

Selenium concentrations were generally at lower concentrations in most species, except for whitefish. The levels of selenium, ensure that with exposure, there is sufficient selenium in place to prevent the depletion of the element which is common in methylmercury exposure and prevents essential functions from occurring. Therefore, it is important to understand the level of exposure and the concentrations present of both methylmercury and selenium. The increase awareness of the effects of selenium on methylmercury exposures is critical to helping mitigate some of the impacts of exposures. The increased levels of selenium in whitefish are important as 
individuals consuming whitefish along with other species of fish that may have higher levels of methylmercury may have some of the impacts of exposures mitigated due to the increased levels of selenium. Due to the positive impacts of selenium, it is important to keep consuming fish at rates which reduce exposure to contaminants such as methylmercury, while still maintaining an intake of beneficial nutrients.

\subsubsection{Pike}

In Ontario, the Ministry of the Environment and Climate Change Canada (2018a), recommends a maximum of 8 sport fish meals per month. It is stated in the guidelines that pickerel and northern pike are top predators and therefore have the highest concentration of mercury (Ministry of Environment and Climate Change Canada, 2018). This concurs with the results of the present study. The observations for mercury concentrations respective to length in Pike were unlike the other species as mercury concentration and length were inversely related. The results for the pike are significant in that a negative relationship was noted, whereby the larger pike were relatively less contaminated and most less than $0.5 \mu \mathrm{g} / \mathrm{g}$ wet weight of mercury whereas to our knowledge, no other study has reported this type of relationship. This was contrary to what was identified in previous studies (Health Canada, 2010; Glass, Sorensen \& Rapp, 2000; Jewett et al, 2002; Lavigne, Lucotte \& Paquet, 2010; Sandheinrich \& Drevnick, 2016; Verdon, 1991; Zamani-Ahmadmahmoodi, Bakhtiari \& Martin, 2014).

Of the 26 samples, 14 of the identified samples were below the consumption guideline of $0.5 \mu \mathrm{g} / \mathrm{g}$ (or ppm). As shown in the results (Figure 7), where $\mathrm{n}=26,29 \%$ of the variation in total mercury was attributable to variation in body length in pike, being statistically significant with $\mathrm{p}=0.005$. When the second set of data was added (Figure 8), the additional 5 samples 
skewed the data resulting in only $10 \%$ of variation in total mercury being attributable to variation in body length in pike with a $\mathrm{p}=0.09$.

One of the hypotheses for this relationship is the origin of the fish species which were ultimately obtained from the Albany River. The Albany River contains water which diverts from the James Bay drainage basin and has many associated tributaries (Minkin et al., 2014). The diversions and associated tributaries create opportunities for Pike from various systems to enter the Albany River. As bioaccumulation occurs when Pike consume fish which have subsequently consumed other fish and species on lower trophic levels, bioaccumulation occurs within the fish. The various samples of Pike collected from the Albany River enter through tributaries which may not have as many trophic levels and therefore, may not accumulate such high concentrations of methylmercury. As stated in a study by Kasper et al. (2009), to accurately understand the concentrations in fish it is important to first understand their trophic level, and the various lower trophic levels from their places of origin. Understanding the concentrations in the associated tributaries which flow into the Albany River would provide a more accurate representation of the methylmercury concentrations in Pike. Therefore, further analysis and monitoring of Pike species, not only in Albany River, but also in its associated tributaries would benefit in understanding the decreased concentrations of methylmercury with increasing lengths.

\subsection{Human Health Risk Assessment}

For the human health risk assessment, intakes were calculated on a daily frequency. This frequency created a standard intake that could be applied to the population based on specific individual frequencies of consumption per species. The average time, exposure duration, and exposure frequency were all standardized using a numerical value of 1 as the units and values 
used all cancelled out. The contact rate used was standardized on a daily frequency for all age groups and species to a value of $0.02143 \mathrm{~kg} / \mathrm{day}$. This value, indicates that the average person would be consuming $0.02143 \mathrm{~kg} /$ day of fish (general) on a daily basis per year using Health Canada's guideline of 2 fish meals/week (75g/meal) (Health Canada, 2007a). The data obtained from the calculation of the intakes and the hazard index indicates what the extent of exposure is per age group and per species, as well as how the risk of exposure can be decreased. The following breakdown per species and per age group expand on the findings.

\subsubsection{Species-specific}

\subsubsection{Pike}

Using the sample means obtained for Pike (table 4), and a standard contact rate of $0.02143 \mathrm{~kg} / \mathrm{day}$, the variances in the populations is attributed to the average bodyweights used for the age groups. The intakes calculated for each age group represent the daily intake relative to the constant values used for exposure frequency, exposure duration and averaging time for the human health risk assessment. Relative to the Health Canada tolerable daily intake of 0.0002 $\mathrm{mg} / \mathrm{kg}_{\mathrm{bw}} / \mathrm{day}$ for children below the age of 13 (Health Canada, 2010), consumption of Pike was exceeding the tolerable daily intake for the following age groups: 3 to $6=0.006 \mathrm{mg} / \mathrm{kg}_{\mathrm{bw}} / \mathrm{day} ; 6$ to $11=0.003 \mathrm{mg} / \mathrm{kg}_{\mathrm{bw}} / \mathrm{day}$ and 11 to $16=0.0002 \mathrm{mg} / \mathrm{kg}_{\mathrm{bw}} / \mathrm{day}$. Relative to the Health Canada limit of $0.00047 \mathrm{mg} / \mathrm{kg}_{\mathrm{bw}} /$ day for adults (Health Canada, 2010), both age groups of 16 to $21=0.0002$ $\mathrm{mg} / \mathrm{kg}_{\mathrm{bw}} / \mathrm{day}$ and $21+=0.0001 \mathrm{mg} / \mathrm{kg}_{\mathrm{bw}} / \mathrm{day}$ were below the tolerable daily intake.

The hazard index, was exceeded for the following age groups, 3 to 6 at 2.88, and 6 to 11 at 1.68. As these values are compared to a conventional value of 1.0, the hazard index for the 3 to 6 age group was exceeded by nearly triple. The value for the age group between 6 to 11 was exceeded by almost double. That means, in order to reduce the risk, the daily intake of fish 
would need to be reduced by one third (to $0.01429 \mathrm{~kg} /$ day) for age groups between 3 to 6 and by half for 6 to $11(0.01072 \mathrm{~kg} / \mathrm{day})$. Therefore, children consuming an average of $0.02143 \mathrm{~kg} / \mathrm{day}$ of pike would be at risk for exceeding the recommended limits of mercury consumption.

The values for the remaining age groups (11 to $16 ; 16$ to $21 ; 21+$ ) all had hazard index values below 1, therefore indicating an acceptable hazard based on an RfD value of 0.00047 $\mathrm{mg} / \mathrm{kg}_{\mathrm{bw}} /$ day for adults set by Health Canada (2010). Therefore, adults consuming an average of $0.02143 \mathrm{~kg} /$ day of pike would not be at risk for exceeding the recommended limits of mercury consumption. However, this value may change based on body weight and frequency of consumption. If an individual has a lower body weight and is consuming pickerel more frequently than the recommended intake, the intake and ultimately the hazard index will be exceeded.

\subsubsection{Pickerel}

Using the sample means obtained for pickerel (table 4), and a standard contact rate of $0.02143 \mathrm{~kg} /$ day was used to calculate the intake and the hazard index for each age group. Relative to the Health Canada tolerable daily intake of $0.0002 \mathrm{mg} / \mathrm{kg}_{\mathrm{bw}} /$ day for children below the age of 13 (Health Canada, 2010), consumption of pickerel exceeded the tolerable daily intake for the following age groups; 3 to $6=0.0006 \mathrm{mg} / \mathrm{kg}_{\mathrm{bw}} / \mathrm{day} ; 6$ to $11=0.0004 \mathrm{mg} / \mathrm{kg}_{\mathrm{bw}} / \mathrm{day}$ and 11 to $16=0.0002 \mathrm{mg} / \mathrm{kg}_{\mathrm{bw}} / \mathrm{day}$. Relative to the Health Canada limit of $0.00047 \mathrm{mg} / \mathrm{kg}_{\mathrm{bw}} / \mathrm{day}$ for adults (Health Canada, 2010), both age groups of 16 to $21=0.0002 \mathrm{mg} / \mathrm{kg}_{\mathrm{bw}} / \mathrm{day}$ and $21+=0.0001$ $\mathrm{mg} / \mathrm{kg}_{\mathrm{bw}} /$ day were below the tolerable daily intake.

The hazard index, was exceeded for the following age groups, 3 to 6 at 3.17, and 6 to 11 at 1.85 . As these values are compared to a conventional value of 1.0 , the hazard index for the 3 to 6 age group was exceeded by triple. The value for the age group between 6 to 11 was 
exceeded by almost double. That means, in order to reduce the risk, the daily intake of pickerel would need to be reduced by one third (to $0.01429 \mathrm{~kg} /$ day) for age groups between 3 to 6 and by half for 6 to $11(0.01072 \mathrm{~kg} / \mathrm{day})$. Therefore, children consuming an average of $0.02143 \mathrm{~kg} / \mathrm{day}$ of pickerel would be at risk for exceeding the recommended limits of mercury consumption.

The values for the remaining age groups (11 to $16 ; 16$ to $21 ; 21+$ ) all had hazard index values below 1, therefore indicating an acceptable hazard based on an RfD value of 0.00047 $\mathrm{mg} / \mathrm{kg}_{\mathrm{bw}} /$ day for adults set by Health Canada (2010). Therefore, adults consuming an average of $0.02143 \mathrm{~kg} / \mathrm{day}$ of pickerel would not be at risk for exceeding the recommended limits of mercury consumption. However, this value may change based on body weight and frequency of consumption. If an individual has a lower body weight and is consuming pickerel more frequently than the recommended intake, the intake and ultimately the hazard index will be exceeded.

\subsubsection{Sturgeon/Carp}

Using the sample means obtained for sturgeon/carp (table 4), and a standard contact rate of $0.02143 \mathrm{~kg} / \mathrm{day}$, was used for the age groups. Relative to the Health Canada limit of 0.0002 $\mathrm{kg} /$ day for children below the age of 13 (Health Canada, 2010), consumption of sturgeon/carp that exceeded the tolerable daily intake was exceeded for the following age groups; 3 to $6=0.0006 \mathrm{mg} / \mathrm{kg}_{\mathrm{bw}} / \mathrm{day}, 6$ to $11=0.0004 \mathrm{mg} / \mathrm{kg}_{\mathrm{bw}} / \mathrm{day}$ and 11 to $16=0.0002 \mathrm{mg} / \mathrm{kg}_{\mathrm{bw}} / \mathrm{day}$. Relative to the Health Canada limit of $0.00047 \mathrm{mg} / \mathrm{kg}_{\mathrm{bw}} /$ day for adults (Health Canada, 2010), both age groups of 16 to $21=0.0002 \mathrm{mg} / \mathrm{kg}_{\mathrm{bw}} / \mathrm{day}$ and $21+=0.0001 \mathrm{mg} / \mathrm{kg}_{\mathrm{bw}} /$ day were below the limits.

The hazard index, was exceeded for the following age groups, 3 to 6 at 2.88, and 6 to 11 at 1.68. As these values are compared to a conventional value of 1.0 , the hazard index for the 3 to 6 age group was exceeded by nearly triple. The value for the age group between 6 to 11 was 
exceeded by almost double. That means, in order to reduce the risk, the daily intake of sturgeon/carp would need to be reduced by one third (to $0.01429 \mathrm{~kg} /$ day) for age groups between 3 to 6 and by half for 6 to $11(0.01072 \mathrm{~kg} / \mathrm{day})$. Therefore, children consuming an average of $0.02143 \mathrm{~kg} / \mathrm{day}$ of pike would be at risk for exceeding the recommended limits of mercury consumption.

The values for the remaining age groups (11 to 16,16 to $21 \& 21+$ ) all had hazard index values below 1, therefore indicating an acceptable hazard based on an RfD value of 0.00047 $\mathrm{mg} / \mathrm{kg}_{\mathrm{bw}} /$ day for adults set by Health Canada (2010). Therefore, adults consuming an average of $0.02143 \mathrm{~kg} /$ day of sturgeon/carp would not be at risk for exceeding the recommended limits of mercury consumption. However, this value may change based on body weight and frequency of consumption. If an individual has a lower body weight, and is consuming pickerel more frequently than the recommended intake, the intake and ultimately the hazard index will be exceeded.

\subsubsection{Whitefish}

The sample means obtained for sturgeon/carp (table 4), and a standard contact rate of $0.02143 \mathrm{~kg} / \mathrm{day}$, was used for the age groups. Relative to the Health Canada limit of 0.0002 $\mathrm{mg} / \mathrm{kg}_{\mathrm{bw}} / \mathrm{day}$ for children below the age of 13 (Health Canada, 2010), consumption of whitefish that exceeded the tolerable daily intake was exceeded for the following age groups: 3 to $6=0.00036 \mathrm{mg} / \mathrm{kg}_{\mathrm{bw}} /$ day and 6 to $11=0.0002 \mathrm{mg} / \mathrm{kg}_{\mathrm{bw}} / \mathrm{day}$. The category for ages 11 to $16 \mathrm{did}$ not exceed the Health Canada limit as intakes were $0.000087 \mathrm{mg} / \mathrm{kg}_{\mathrm{bw}} / \mathrm{day}$. Relative to the Health Canada limit of $0.00047 \mathrm{mg} / \mathrm{kg}_{\mathrm{bw}} / \mathrm{day}$ for adults (Health Canada, 2010), both categories of 16 to $21=0.000069 \mathrm{mg} / \mathrm{kg}_{\mathrm{bw}} /$ day and $21+=0.000062 \mathrm{mg} / \mathrm{kg}_{\mathrm{bw}} /$ day were below the limits. 
The hazard index, was exceeded for the age groups between 3 to 6 at 1.32. As these values are compared to a conventional value of 1.0, the hazard index for the 3 to 6 age group was exceeded by a third. That means, in order to reduce the risk, the daily intake of whitefish would need to be reduced by one sixth for age groups between 3 to 6 ( $0.01786 \mathrm{~kg} / \mathrm{day})$. Therefore, children between the ages of 3 to 6 consuming an average of $0.02143 \mathrm{~kg} / \mathrm{day}$ of whitefish would be at risk for slightly exceeding the recommended limits of mercury consumption.

The values for the remaining age groups (6 to 11,11 to 16,16 to $21 \& 21+$ ) all had hazard index values below 1, therefore indicating an acceptable hazard based on an RfD value of $0.00047 \mathrm{mg} / \mathrm{kg}_{\mathrm{bw}} / \mathrm{day}$ for adults set by Health Canada (2010). Therefore, adults consuming an average of $0.02143 \mathrm{~kg} /$ day of whitefish would not be at risk for exceeding the recommended limits of mercury consumption. Whitefish were observed to have lower concentrations of mercury and therefore it is a safer species to consume. However, this value may change based on body weight of the individual consuming and frequency of consumption. If an individual has a lower body weight and is consuming whitefish more frequently than the recommended intake, the intake and ultimately the hazard index will be exceeded.

\subsubsection{Population-specific}

\subsubsection{Fish Consumption Guidelines}

The Ministry of the Environment and Climate Change Canada (2018), has developed guidelines to assist in the consumption of fish to limit exposure. The guidelines, created for each province, were designed for recreational and subsistence fishers. The guidelines were created for areas that are commonly known for fishing, areas with pollution sources nearby and those that have been a part of a monitoring program of fish studies (Ministry of Environment and Climate Change Canada ,2018). These guidelines document various aspects of fishing which assist in 
identifying factors which may increase exposure. Factors such as location, type of fish, length of species and consumption are detailed in these guidelines.

Based on location, water bodies commonly known for fishing such as the Albany River and its connecting channels, are identified in the guidelines. It's susceptibility to contamination is also increased due to the pollution sources that are nearby. The fish species identified in the guidelines, which were last updated in 2015 were lake whitefish. longnose carp, northern pike, white carp, and pickerel. These were the species that were identified and tested for contaminants. These guidelines identify the number of meals per month that should be consumed for the general population and for sensitive populations such as women of child-bearing age and children that are under the age of 15 . Generally, the portion sizes for the sensitive populations are at least half, if not less, based on the length of the fish. The length of fish is generally measured from the top of the nose to the tip of the tail. As methylmercury is distributed throughout the body, there is no way to eliminate methylmercury during preparation, therefore, the best mechanism for limiting exposure is to consume smaller sizes of fish. These guidelines, along with the human health risk assessment are effective in limiting exposure in communities such as Fort Albany. As eliminating the exposure short has already been observed to have other detrimental impacts on health, minimizing exposure by following both the guideline and the human health exposure assessment will be reducing any adverse impacts of methylmercury within the population.

\subsubsection{Children}

According to the human health risk assessment completed, the age groups with the most concerning hazard index were ages 3 to 6 and 6 to 11. The consumption of pickerel, pike, sturgeon, and carp for age groups 3 to 6 showed a hazard index almost consistently triple the 
acceptable value. For whitefish, the value was almost double. For the age groups between 6 to 11 in pickerel, pike, sturgeon, and carp, these rates were almost double. For whitefish, this value was below the standard value indicating a below-concerning level of exposure. These age groups, according to Health Canada (2010), are considered sensitive populations. Therefore, the consumption of fish, per month, should be based on the age of the individual and the species and length of the fish caught.

\subsubsection{Adults}

As per the human health risk assessment that was completed, age groups above the age of 11 (11 to 16,16 to $21 \& 21+$ ) did not have a hazard index value above 1 , indicating that they were not above the risk level of $0.00047 \mathrm{mg} / \mathrm{kg}_{\mathrm{bw}} / \mathrm{day}$. The hazard index values were all below 1 , indicating that this level was not exceeded for these age groups, for any species consumed. However, as this value was estimated on an average of 2 fish meals per week at $75 \mathrm{~g}$, therefore, it is important to note that anyone consuming above these amounts may be at risk for an increased level of methylmercury exposure. Pregnant women, nursing mothers and women of childbearing age, as stated by Health Canada guidelines (Health Canada, 2010) are considered sensitive populations therefore, the consumption of fish, per month, should be based on the age of the individual and the species and length of the fish caught. Consumption of fish during pregnancy and nursing should be limited as transplacental and transfer through breast milk can impact the health of the baby or fetus.

\subsection{Limitations}

\subsubsection{Study Limitations}

The limitations for this study were primarily sample size. Samples obtained were dependent on the species that were present in the river throughout the defined study period. 
However, to refine the process, obtaining more samples for a longer period of time would assist in comparing the statistical significance between the species along with individual analysis. Obtaining more samples would provide a greater representation of the population of the river. Therefore, observations of the relationships between the lengths and mercury concentrations, especially ones such as the inverse relationship for pike length and mercury concentration, can be explored further. The relationship observed in pike demonstrates a need for further research and analysis to be done. A theory for this relationship was identified. To further support this theory, obtaining these additional samples throughout different stages of the river would also assist in determining whether or not this variance is truly significant. Further sampling, and long term biomonitoring of mercury concentrations in these would be beneficial to identify mercury exposures through fish and to determine whether the levels of mercury throughout the river are changing.

\subsubsection{Limitations and uncertainties in Human Health Risk Assessment}

Though the process is completed using standardized values, there are still many uncertainty factors that are involved in the human health risk assessment calculations. The risk assessment process is also an over estimated exposure. The dietary intakes obtained used a standard value Health Canada value of 2 fish meals per week of $75 \mathrm{~g} / \mathrm{week}$. This is an over estimation of the exposure as the younger age groups may not consume such high amounts of fish. This may also be an underestimation of the exposure for the other age groups which may consume fish more frequently. The dietary habits amongst these communities are also reliant on a number of factors, primarily weather and the availability of certain species. Obtaining data regarding consumption patterns relative to the community would be beneficial in refining the data. Obtaining specific values in regard to body weight and consumption would also help in 
refining the risk assessment process. The difficulties with body weight is that obtaining exact values of the entire population would be costly, time consuming and may not obtain a $100 \%$ participation rate due to privacy. Therefore, obtaining long-term food consumption data would benefit in obtaining more specific consumption data specifically for Fort Albany First Nation. Future work may also incorporate gender-specific consumption rates as identified previously that men tend to consume higher rates of fish.

As the risk assessment process is generally completed on a grouped basis, a variety of factors such as body weight and consumption patterns as previously mentioned could impact the values. Completing a risk assessment for individuals would be costly and timely therefore, completing it on a group basis provides an accurate estimate for risk values. Due to the potential for exposure of methylmercury to vulnerable populations such as the elderly and children, and because of the importance of fish consumption amongst First Nations communities such as Fort Albany First Nation, the values obtained through the risk assessment process should be used as guidelines when evaluating dietary exposures amongst these communities.

\subsection{Conclusions}

With the increasing growth of Canada's natural resource sector around areas such as Fort Albany First Nation, identifying what the impacts are on these communities and on human health is critical. This study aimed to address the knowledge gap by identifying the level of methylmercury in species such as pike, sturgeon, whitefish, pickerel and carp, which are frequently consumed. These species, which are readily part of a traditional diet, are rich in nutrients, therefore abstaining from consumption not only depletes the health of the community but contributes to the ever-increasing issue of food security. 
This study has identified three key components that need to be addressed through further research. Firstly, the human health risk assessment identified a need to monitor consumption levels of fish by children. As identified during the risk assessment, children between the age groups of 3 to 6 and 6 to 11 are susceptible to being exposed to higher levels of methylmercury, if consuming an average of 2 fish meals per week ( $75 \mathrm{~g}$ per meal) due to their lower bodyweights. As this study was done with standardized weights, it would be beneficial to assess using the accurate body weight of the individual to determine what their serving portions should be on a weekly basis. Children, at a younger age, are also susceptible to greater impacts from methylmercury exposure as they are still in their growth stages and it can greatly impact their development. Children are also considered sensitive populations, along with pregnant women, who should also limit their consumption of fish that are known to have higher concentrations of methylmercury, or if consuming, limit portion sizes. The Ministry of Environment and Climate Change Canada has developed, fish consumption guidelines to limit exposures, especially for sensitive populations. The guidelines for Albany River identify species that have been identified and the serving portions relative to the length. Fish have the ability to bioaccumulate methylmercury, and therefore species on higher trophic levels accumulate higher concentrations of methylmercury. Though this is a good guideline to use when consuming fish from Albany River, our study displayed in the statistical analysis that the length of the fish and its proportion to methylmercury concentrations may not be as expected.

Lastly, as the Arctic dilemma has been identified as a factor for the decreased consumption of traditional foods, long-term biomonitoring of species frequently consumed would be beneficial in addressing community concerns. Our analysis identified a a need for more monitoring of species present in the Albany River to identify mercury concentrations in species 
frequently consumed such as Pike, Pickerel, Sturgeon, Carp and Whitefish. As fish is frequently consumed by people in Fort Albany First Nation, it is crucial to have a constant, and long-term biomonitoring of the species present. Our study identified the inverse relationship between Pike length and methylmercury concentrations. This has identified a need for further monitoring with an increased sample size at varying points of the river. The inverse relationship displayed in the Pike samples obtained, identify a need for constant monitoring to ensure the consumption guidelines are accurate for communities impacted by food security that rely on food from traditional practices such as fishing. It is important to test species not only at various lengths, but also at various stages of the river to ensure that there is an accurate enough sample of the fish entering the river through the various tributaries and diversions. Consumption guidelines which generally reflect an increasing concentration in methylmercury with an increase in length may not be entirely accurate and therefore deter people from consumption. Not only does this deplete the intake of essential nutrients obtained from the diet, but deters people from traditional practices such as fishing which may contribute to overall wellbeing.

Using the data obtained from this study, species with higher concentrations of mercury and at-risk populations were identified and using a combination of scientific and traditional knowledge and ultimately appropriate recommendations were made to the community to reduce exposures. The data from this study can be applied to other remote communities which rely on traditional diets of fish, and may be at risk of higher contaminant exposure. Through collaborative efforts and the required expertise and resources, the project ultimately addressed one of the most important routes for exposures to mercury within Fort Albany. 


\section{$\underline{\text { References }}$}

Arctic Monitoring and Assessment Programme (AMAP). (2005). AMAP Assessment 2002: Heavy Metals in the Arctic. Oslo, Norway: Author. Retrieved from https://www.amap.no/documents/doc/amap-assessment-2002-heavy-metals-in-the$\operatorname{arctic} / 97$

Arctic Monitoring and Assessment Programme (AMAP). (2009). AMAP assessment 2000: Human health in the Arctic. Oslo, Norway: Author. Retrieved from https://www.amap.no/documents/doc/amap-assessment-2009-human-health-in-the$\operatorname{arctic} / 98$

Assembly of First Nations Environmental Stewardship Unit. (2005). Overview of environmental issues facing First Nations: Context for participation in nuclear fuel waste management issues. Retrieved from https://www.nwmo.ca/ /media/Site/Files/PDFs/2015/11/04/17/30/406_11-AFN10. ashx?la=en

Bakir, F., Damluji, S., Amin-Zaki, L., Murtadha, M., Khalidi, A., Al-Rawi, N., . . Doherty, R. (1973). Methylmercury Poisoning in Iraq. Science, 181(4096), 230-241. Retrieved from http://www.jstor.org/stable/1736448

Berti, P. R., Hamilton, S. E., Receveur, O., \& Kuhnlein, H. V. (1999). Food use and nutrient adequacy in Baffin Inuit children and adolescents. Canadian Journal of Dietetic Practice and Research, 60(2), 63. Retrieved from https://search-proquestcom.ezproxy.lib.ryerson.ca/docview/220823760?pq-origsite=summon

Branfireun, B. A., Roulet, N. T., Kelly, C. A., \& Rudd, J. W. M. (1999). In situ sulphate stimulation of mercury methylation in a boreal peatland: Toward a link between acid rain 
and methylmercury contamination in remote environments. Global Biogeochemical Cycles, 13(3), 743-750. doi:10.1029/1999GB900033

Braune, B. M., Outridge, P. M., Fisk, A. T., Muir, D. C. G., Helm, P. A., Hobbs, K., . . Stirling, I. (2005). Persistent organic pollutants and mercury in marine biota of the canadian arctic: An overview of spatial and temporal trends. Science of the Total Environment, 351, 4-56. doi:10.1016/j.scitotenv.2004.10.034

Broussard, L. A., Hammett-Stabler, C. A., Winecker, R. E., \& Ropero-Miller, J. D. (2002). The toxicology of mercury. Laboratory Medicine, 33(8), 614-625. doi:10.1309/5HY1-V3NE2LFL-P9MT

Centre de toxicologie du Québec (CTQ). (n.d.). About the CTQ. Retrieved from https://www.inspq.qc.ca/en/ctq/about

Chan, H. M., H.M., \& Receveur, O. (2000). Mercury in the traditional diet of Indigenous peoples in Canada. Environmental Pollution, 110(1), 1-2. doi:10.1016/S0269-7491(00)00061-0

Chen, Z., \& Riggs, A. D. (2011). DNA methylation and demethylation in mammals. The Journal of Biological Chemistry, 286(21), 18347-18353. doi:10.1074/jbc.R110.205286

Cree Board of Health and Social Services of James Bay (CBHSSJB). (2012).

Nituuchischaayihtitaau Aschii multi-community environment and health longitudinal study in Eeyou Istchee: community reports. Retrieved from: http://creehealth.org/clinicalprotocols/nituuchischaayihtitaau-aschii-community-results.

Damstra, T., Page, S. W., Herrman, J. L., \& Meredith, T. (2002). Persistent organic pollutants: Potential health effects? Journal of Epidemiology and Community Health (1979), 56(11), 824-825. doi:10.1136/jech.56.11.824

Damman, S., Eide, W. B., \& Kuhnlein, H. V. (2008). Indigenous peoples' nutrition transition in 
a right to food perspective. Food Policy, 33(2), 135-155.

doi:10.1016/j.foodpol.2007.08.002

Depew, D. C., Basu, N., Burgess, N. M., Campbell, L. M., Devlin, E. W., Drevnick, P. E., . . . Wiener, J. G. (2012). Toxicity of dietary methylmercury to fish: Derivation of ecologically meaningful threshold concentrations. Environmental Toxicology and Chemistry, 31(7), 1536-1547. doi:10.1002/etc.1859

Desrosiers, M., Planas, D., \& Mucci, A. (2006). Short-term responses to watershed logging on biomass mercury and methylmercury accumulation by periphyton in boreal lakes. Canadian Journal of Fisheries and Aquatic Sciences, 63(8), 1734-1745. doi:10.1139/f06077

Dewailly, É. (2006). Canadian Inuit and the Arctic dilemma. Oceanography, 19(2), 88-89. doi:10.5670/oceanog.2006.71

D'Itri, F. (1991). Mercury contamination-what we have learned since Minamata. Environmental Monitoring and Assessment, 19(1-3), 165-182. doi:10.1007/BF00401309

Eklöf, K., Meili, M., Åkerblom, S., von Brömssen, C., Bishop, K., Stockholms universitet, . . . Institutionen för tillämpad miljövetenskap (ITM). (2013). Impact of stump harvest on run-off concentrations of total mercury and methylmercury. Forest Ecology and Management, 290, 83-94. doi:10.1016/j.foreco.2012.05.039

Food and Agriculture Organization of the United Nations (FOA). (1996) Rome Declaration on World Food Security and World Food Summit Plan of Action. Rome, Italy: FOA. Retrieved from http://www.fao.org/docrep/003/w3613e/w3613e00.HTM

Food and Agriculture Organization of the United Nations (FOA) \& World Health Organization (WHO). (2002). Human Vitamin and Mineral Requirements: Report of a joint FAO/WHO 
expert consultation Bangkok, Thailand. Rome, Italy: FOA Rome, Food and Nutrition Division. Retrieved from http://www.fao.org/docrep/004/y2809e/y2809e00.htm

Gage, J. C. (1975). Mechanisms for the biodegradation of organic mercury compounds: The actions of ascorbate and of soluble proteins. Toxicology and Applied Pharmacology, 32(2), 225-238. doi:10.1016/0041-008X(75)90215-X

Garcia, E., \& Carignan, R. (1999). Impact of wildfire and clear-cutting in the boreal forest on methyl mercury in zooplankton. Canadian Journal of Fisheries and Aquatic Sciences, 56(2), 339-345. doi:10.1139/cjfas-56-2-339

Gaudin, V. L., Receveur, O., Walz, L., Girard, F., \& Potvin, L. (2014). A mixed methods inquiry into the determinants of traditional food consumption among three Cree communities of Eeyou Istchee from an ecological perspective. International Journal of Circumpolar Health, 73(1), 24918-13. doi:10.3402/ijch.v73.24918

George, P., \& Preston, R. (1987). "Going in Between": The impact of European technology on the work patterns of the west main Cree of Northern Ontario. The Journal of Economic History, 47(2), 447-460. Retrieved from http://www.jstor.org/stable/2122241

Glass, G. E., Sorensen, J. A., \& Rapp, G. R. (2000). Methylmercury Bioaccumulation Dependence on Northern Pike Age and Size in 20 Minnesota Lakes. ACS Symposium Series Persistent, Bioaccumulative, and Toxic Chemicals I,150-163. doi:10.1021/bk2001-0772.ch011

Graham, A. M., Bullock, A. L., Maizel, A. C., Elias, D. A., \& Gilmour, C. C. (2012). Detailed assessment of the kinetics of hg-cell association, hg methylation, and methylmercury degradation in several desulfovibrio species. Applied and Environmental Microbiology, 78(20), 7337-7346. doi:10.1128/AEM.01792-12 
Grandjean, P., Weihe, P., White, R. F., Debes, F., Araki, S., Yokoyama, K., . . Jørgensen, P. J. (1997). Cognitive deficit in 7-year-old children with prenatal exposure to methylmercury. Neurotoxicology and Teratology, 19(6), 417-428. doi:10.1016/S0892-0362(97)00097-4

Grandjean, P., Satoh, H., Murata, K., \& Eto, K. (2010). Adverse effects of methylmercury: Environmental health research implications. Environmental Health Perspectives, 118(8), 1137-1145. doi:10.1289/ehp.0901757

Harada, M. (1995). Minamata disease: Methylmercury poisoning in Japan caused by environmental pollution. CRC Critical Reviews in Toxicology, 25(1), 1-24. doi:10.3109/10408449509089885

Harari, R., Harari, F., Gerhardsson, L., Lundh, T., Skerfving, S., Strömberg, U., \& Broberg, K. (2012). Exposure and toxic effects of elemental mercury in gold-mining activities in Ecuador. Toxicology Letters, 213(1), 75-82. doi:10.1016/j.toxlet.2011.09.006

Hargan, K. E., Nelligan, C., Jeziorski, A., Rühland, K. M., Paterson, A. M., Keller, W., \& Smol, J. P. (2016). Tracking the long-term responses of diatoms and cladocerans to climate warming and human influences across lakes of the ring of fire in the far north of Ontario, Canada. Journal of Paleolimnology, 56(2), 153-172. doi:10.1007/s109330169901-7

Harley, J., Lieske, C., Bhojwani, S., Castellini, J. M., López, J. A., \& O’Hara, T. M. (2015). Mercury and methylmercury distribution in tissues of sculpins from the Bering sea. Polar Biology, 38(9), 1535-1543. doi:10.1007/s00300-015-1716-х

Health Canada. (1979). Guidelines for Canadian drinking water quality: Guideline technical document-Mercury. Retrieved from https://www.canada.ca/en/healthcanada/services/publications/healthy-living/guidelines-canadian-drinking-water-qualityguideline-technical-document-mercury.html?wbdisable=true 
Health Canada. (2007a). Eating Well with Canada's FoodGuide First Nations, Inuit and Métis. (Catalogue no. H34-159/2007E-PDF). Retrieved from https://www.canada.ca/content/dam/hc-sc/migration/hc-sc/fn-an/alt_formats/fnihbdgspni/pdf/pubs/fnim-pnim/2007_fnim-pnim_food-guide-aliment-eng.pdf

Health Canada. (2007b). Human Health Risk Assessment of Mercury in Fish and Health Benefits of Fish Consumption. Retrieved from https://www.canada.ca/content/dam/hcsc/migration/hc-sc/fn-an/alt_formats/hpfb-dgpsa/pdf/nutrition/merc_fish_poisson-eng.pdf Health Canada. (2010). Federal Contaminated Site Risk Assessment in Canada, Part II: Health Canada Toxicological Reference Values (TRVs) and Chemical-Specific Factors, Version 2.0. (Catalogue no. H128-1/11-638E-PDF). Retrieved from http://publications.gc.ca/collections/collection_2012/sc-hc/H128-1-11-638-eng.pdf

Hlimi, T. (2011). Identifying barriers to traditional game consumption in First Nation adolescents in remote northern communities in Ontario, Canada (Unpublished Masters dissertation). University of Waterloo, Waterloo, Canada. Retrieved from https://uwspace.uwaterloo.ca/bitstream/handle/10012/5898/Hlimi_Tina.pdf?sequence=1

Hlimi, T., Skinner, K., Hanning, R. M., Martin, I. D., \& Tsuji, L. J. S. (2012) Traditional food consumption behavior and concern with environmental contaminants among Cree schoolchildren of the Mushkegowuk territory. International Journal of Circumpolar Health, 71(1), 17344-17349. doi:10.3402/ijch.v71i0.17344

Hong, Y., Kim, Y., \& Lee, K. (2012). Methylmercury exposure and health effects. Journal of Preventive Medicine and Public Health = Yebang Üihakhoe Chi, 45(6), 353. doi:10.3961/jpmph.2012.45.6.353

Hosokawa, Y. (1993). Remediation work for mercury contaminated bay - experiences of 
Minamata bay project, Japan. Water Science and Technology, 28(8-9), 339.

doi:10.2166/wst.1993.0632

Indigenous and Northern Affairs Canada (INAC). (2006). Northern Contaminants Program

(NCP) Operational Management Guide. Retrieved from http://www.aadnc-

aandc.gc.ca/DAM/DAM-INTER-HQ/STAGING/texte-

text/omg_1100100035667_eng.pdf

Jewett, S. C., Zhang, X., Sathy Naidu, A., Kelley, J. J., Dasher, D., \& Duffy, L. K. (2003).

Comparison of mercury and methylmercury in northern pike and Arctic grayling from Western Alaska rivers. Chemosphere, 50(3), 383-392. doi:10.1016/S00456535(02)00421-6

Karagas, M. R., Choi, A. L., Oken, E., Horvat, M., Schoeny, R., Kamai, E., . . Korrick, S. (2012). Evidence on the human health effects of low-level methylmercury exposure. Environmental Health Perspectives, 120(6), 799-806. doi:10.1289/ehp.1104494

Kasper, D., Palermo, E. F. A., Dias, A. C. M. I., Ferreira, G. L., Leitão. R. P., Branco, C. W. C. \& Malm, O. (2009). Mercury distribution in different tissues and trophic levels of fish from a tropical reservoir, Brazil. Neotrophical Ichthyology, 7 (4),751-758. http://dx.doi.org/10.1590/S1679-62252009000400025

Klaassen, C. D., Casarett, L. J., \& Doull, J. (2013). Casarett and Doull's toxicology: The basic science of poisons (8th ed.). New York: McGraw-Hill Education / Medical.

Kuhnlein, H. V. \& Chan, L. H. M. (2000) Environment and contaminants in traditional food systems of Northern Indigenous peoples. Annual Review of Nutrition, 20, 595-626. doi:10.1146/annurev.nutr.20.1.595

Receveur, O., Boulay, M., \& Kuhnlein, H. V. (1997). Decreasing traditional food use affects diet 
quality for adult Dene/Métis in 16 communities of the Canadian Northwest Territories. The Journal of Nutrition, 127(11), 2179. https://doi.org/10.1093/jn/127.11.2179

Kuhnlein, H. V., \& Receveur, O. (2007). Local cultural animal food contributes high levels of nutrients for arctic Canadian Indigenous adults and children. The Journal of Nutrition, 137(4), 1110. doi: 10.1093/jn/137.4.1110

Kuhnlein, H. V., Receveur, O., Soueida, R., \& Berti, P. R. (2008). Unique patterns of dietary adequacy in three cultures of Canadian Arctic Indigenous peoples. Public Health Nutrition, 11(4), 349-360. doi:10.1017/S1368980007000353

Kuhnlein, H. V., Receveur, O., Soueida, R., \& Egeland, G. M. (2004). Arctic Indigenous peoples experience the nutrition transition with changing dietary patterns and obesity. The Journal of Nutrition, 134(6), 1447.

Lajeunesse, A. (2007). The distant early warning line and the canadian battle for public perception. Canadian Military Journal, 8(2), 51. Retrieved from http://www.journal.forces.gc.ca/vo8/no2/lajeunes-eng.asp

Lavigne, M., Lucotte, M., \& Paquet, S. (2010). Relationship between mercury concentration and growth rates for walleyes, northern pike, and lake trout from Quebec lakes. North American Journal of Fisheries Management, 30(5), 1221-1237. doi:10.1577/M08-065.1

Liberda, E. N., Tsuji, L. J. S., Martin, I. D., Ayotte, P., Dewailly, E., \& Nieboer, E. (2014a). The complexity of hair/blood mercury concentration ratios and its implications. Environmental Research, 134, 286-294. doi:10.1016/j.envres.2014.08.007

Liberda, E. N., Tsuji, L. J. S., Martin, I. D., Cote, S., Ayotte, P., Dewailly, E., \& Nieboer, E. (2014b). Plasma concentrations of persistent organic pollutants in the Cree of Northern 
Quebec, Canada: Results from the multicommunity environment and health study. The Science of the Total Environment, 470-471, 818-828. doi:10.1016/j.scitotenv.2013.10.048

Liberda, E. N., Tsuji, L. J. S., \& Peltier, R. E. (2015). Mining in subarctic Canada: Airborne PM2.5 metal concentrations in two remote First Nations communities. Chemosphere, 139 (Complete), 452-460. doi:10.1016/j.chemosphere.2015.07.058

Liberda, E. N., Wainman, B. C., LeBlanc, A., Dumas, P., Martin, I., \& Tsuji, L. J. S. (2011). Dietary exposure of PBDEs resulting from a subsistence diet in three First Nation communities in the James Bay region of Canada. Environment International, 37(3), 631636. doi:10.1016/j.envint.2010.12.008

McCrea, R. C. \& Fischer, J. D. (1986). Heavy metal and Organochlorine contaminants in the five major Ontario rivers of the Hudson Bay lowland. Water Pollution Research Journal of Canada, 21(2), 225. Retrieved from http://digital.library.mcgill.ca/page-turner3/pageturner.php

Magos, L., \& Clarkson, T. W. (2008). The assessment of the contribution of hair to methyl mercury excretion. Toxicology Letters, 182(1), 48-49. doi:10.1016/j.toxlet.2008.08.010

McCarthy, D. D. P., Crandall, D. D., Whitelaw, G. S., General, Z., \& Tsuji, L. J. S. (2011). A critical systems approach to social learning: Building adaptive capacity in social, ecological, epistemological (SEE) systems. Ecology and Society, 16(3), 18. doi:10.5751/ES-04255-160318

Ministry of Environment and Climate Change Canada. (2018). Eating Ontario Fish (2018-18). Retrieved from https://www.ontario.ca/page/eating-ontario-fish-2017-18\#section-10 Minkin, D., Whitelaw, G. S., McCarthy, D. P. \& Tsuji, L. J. S. (2014). Cultural protection, empowerment and land use planning: Identification of values in support of Fort Albany 
First Nation, Ontario, Canada, community based land use planning. The Canadian Journal of Native Studies, 34(1), 129-150. Retrieved from http://ezproxy.lib.ryerson.ca/login?url=https://search-proquestcom.ezproxy.lib.ryerson.ca/docview/1626237958?accountid=13631

Møller-Madsen, B. (1992). Localization of mercury in CNS of the rat. V. inhalation exposure to metallic mercury. Archives of Toxicology, 66(2), 79-89. doi:10.1007/BF02342499

Mosa, A., \& Duffin, J. (2017). The interwoven history of mercury poisoning in Ontario and Japan. Canadian Medical Association Journal, 189(5), E213-E215. doi:10.1503/cmaj.160943

Muckle, G., Ayotte, P., Dewailly, É., Jacobson, S. W., \& Jacobson, J. L. (2001). Determinants of polychlorinated biphenyls and methylmercury exposure in Inuit women of childbearing age. Environmental Health Perspectives, 109(9), 957-963. doi:10.1289/ehp.01109957

National Research Council. (1983). Risk Assessment in the Federal Government: Managing the Process. Washington, DC: The National Academies Press. https://doi.org/10.17226/366. National Research Council. (2000). Toxicological Effects of Methylmercury. Washington, DC: The National Academies Press. Retrieved from https://www.ncbi.nlm.nih.gov/books/NBK225779/

Nieboer, E., Dewailly, E., Johnson-Down, L., Sampasa-Kanyinga, H., Château-Degat, M., L., Egeland, G. M., Atikessé, L., Robinson, E., Torrie, J. (2013). Environment-and-health study in Eeyou Istchee 2005-2009: Final technical report. Retrieved from http://www.creehealth.org/library/online/nituuchischaayihtitaau-aschii-multi-communityenvironment-and-health-study-eyou 
Nøst, T. H., Breivik, K., Fuskevåg, O., Nieboer, E., Odland, J. Ø., \& Sandanger, T. M. (2013). Persistent organic pollutants in Norwegian men from 1979 to 2007: Intraindividual changes, age-period-cohort effects, and model predictions. Environmental Health Perspectives, 121(11-12), 1292. doi:10.1289/ehp.1206317

Oliveira, C. S., Joshee, L., Zalups, R. K., Pereira, M. E., \& Bridges, C. C. (2015). Disposition of inorganic mercury in pregnant rats and their offspring. Toxicology, 335, 62-71. doi:10.1016/j.tox.2015.07.006

Parízek, J., \& Ostádalová, I. (1967). The protective effect of small amounts of selenite in sublimate intoxication. Experientia, 23(2), 142-143. doi:10.1007/BF02135970

Paustenbach, D. J. (2002). Human and ecological risk assessment: Theory and practice. Chichester: Wiley.

Paustenbach, D., \& Galbraith, D. (2006). Biomonitoring: Is body burden relevant to public health? Regulatory Toxicology and Pharmacology, 44(3), 249-261. doi:10.1016/j.yrtph.2006.01.005

Pirkle, C. M., Muckle, G., \& Lemire, M. (2016). Managing mercury exposure in Northern Canadian communities. Canadian Medical Association Journal, 188(14), 1015-1023. doi:http://dx.doi.org/10.1503/cmaj.151138

Porvari, P., Verta, M., Munthe, J., \& Haapanen, M. (2003). Forestry practices increase mercury and methyl mercury output from boreal forest catchments. Environmental Science \& Technology, 37(11), 2389-2393. doi:10.1021/es0340174

Ralston, N. V. C., \& Raymond, L. J. (2010). Dietary selenium's protective effects against methylmercury toxicity. Toxicology, 278(1), 112-123.doi:10.1016/j.tox.2010.06.004

Restoule, J., Gruner, S., \& Metatawabin, E. (2013). Learning from place: A return to traditional 
Mushkegowuk ways of knowing. Canadian Journal of Education / Revue Canadienne De l'Éducation, 36(2), 68-86.

Richardson, G. M., Currie, D. J. \& Egyed, M. (1995), Does acid rain increase human exposure to mercury? A review and analysis of recent literature. Environmental Toxicology and Chemistry, 14, 809-813. doi:10.1002/etc.5620140510

Rissanen, T., Voutilainen, S., Nyyssönen, K., Lakka, T. A., \& Salonen, J. T. (2000). Fish oilderived fatty acids, docosahexaenoic acid and docosapentaenoic acid, and the risk of acute coronary events: The kuopio ischaemic heart disease risk factor study. Circulation, 102(22), 2677-2679. doi:10.1161/01.CIR.102.22.2677

Sandheinrich, M. B., \& Drevnick, P. E. (2016). Relationship among mercury concentration, growth rate, and condition of northern pike: A tautology resolved? Environmental Toxicology and Chemistry, 35(12), 2910-2915. doi:10.1002/etc.3521

Skerfving, S. B., \& Copplestone, J. F. (1976). Poisoning caused by the consumption of organomercury-dressed seed in Iraq. Bulletin of the World Health Organization, 54(1), 101. Retrieved from https://www.ncbi.nlm.nih.gov/pmc/articles/PMC2366450/

Skinner, K., Hanning, R. M., Desjardins, E., \& Tsuji, L. J. S. (2013). Giving voice to food insecurity in a remote Indigenous community in subarctic Ontario, Canada: Traditional ways, ways to cope, ways forward. BMC Public Health, 13(1), 427-427.

doi:10.1186/1471-2458-13-427

Statistics Canada. (2017). Fort Albany (Part) 67, Indian reserve [Census subdivision], Ontario and Ontario [Province]. Retrieved from http://www12.statcan.gc.ca/censusrecensement/2016/dppd/prof/details/page.cfm?Lang=E\&Geo1=CSD\&Code1=3556093\&Geo2=PR\&Code2=3 
5\&Data=Count\&SearchText=Fort\%20Albany\%20[Part]\%2067\&SearchType=Begins \&S earchPR=01\&B1=All\&GeoLevel=PR\&GeoCode $=3556093 \&$ TABID $=1$

Syversen, T., \& Kaur, P. (2012). The toxicology of mercury and its compounds. Journal of Trace Elements in Medicine and Biology, 26(4), 215-226. doi:10.1016/j.jtemb.2012.02.004

Tam, B. Y., Gough, W. A., Edwards, V., \& Tsuji, L. J. S. (2013). The impact of climate change on the well-being and lifestyle of a First Nation community in the Western James Bay region. The Canadian Geographer / Le Géographe Canadien, 57(4), 441-456. doi:10.1111/j.1541-0064.2013.12033.x

Torrie, J., Bobet, E., Kishchuk, N. \& Webster, A. (2005). The evolution of health status and health determinants in the Cree region (Eeyou Istchee): Eastmain-1-A powerhouse and Rupert diversion sectoral report, Volume 2: Detailed analysis. Retrieved from http://creepublichealth.org

Torres, J., Pintos, V., Gonzatto, L., Domínguez, S., Kremer, E., \& Kremer, C. (2011). Selenium chemical speciation in natural waters: Protonation and complexation behavior of selenite and selenate in the presence of environmentally relevant cations. Chemical Geology, 288(1), 32-38. doi:10.1016/j.chemgeo.2011.06.015

Tsuji, L. J. S., Wainman, B. C., Martin, I. D., Weber, J. P., Sutherland, C., \& Nieboer, E. (2006). Abandoned Mid-Canada radar line sites in the Western James Bay region of Northern Ontario, Canada: A source of organochlorines for First Nations people? Science of the Total Environment, the, 370(2-3), 452-466. doi:10.1016/j.scitotenv.2006.07.033

Ullrich, S. M., Tanton, T. W., \& Abdrashitova, S. A. (2001). Mercury in the aquatic environment: A review of factors affecting methylation. Critical Reviews in Environmental Science and Technology, 31(3), 241-293. doi:10.1080/20016491089226 
United States (U.S.) Department of Health and Human Services. Agency for Toxic Substances and Disease Registry (ATSDR). (1989). Toxicological Profile for Mercury. Atlanta, Georgia: United States (U.S.) Department of Health and Human Services. Retrieved from https://www.atsdr.cdc.gov/toxprofiles/tp46.pdf

United States (U.S.) Environmental Protection Agency. (1992). Guidelines for exposure assessment (Federal Register 57(104):22888-22938). Washington, DC: U.S. Environmental Protection Agency. Retrieved from https://www.epa.gov/sites/production/files/201411/documents/guidelines_exp_assessment.pdf

United States (U.S.) Environmental Protection Agency. (2001). Methylmercury (MeHg); CASRN 22967-92-6. Washington, DC: U.S. Environmental Protection Agency. Retrieved from https://cfpub.epa.gov/ncea/iris/iris_documents/documents/subst/0073_summary.pdf

United States (U.S.) Environmental Protection Agency. (2011). U.S. EPA. Exposure Factors Handbook 2011 Edition (Final Report) (EPA Publication No. 600/R-09/052F), Washington, DC: U.S. Environmental Protection Agency. Retrieved from https://cfpub.epa.gov/ncea/risk/recordisplay.cfm?deid=236252

United States Food and Drug Administration (U.S. FDA). (2017). White Paper: FDA Update/Review of Potential Adverse Health Risks Associated with Exposure to Mercury in Dental Amalgam. Retrieved from https://www.fda.gov/MedicalDevices/ProductsandMedicalProcedures/DentalProducts/De ntalAmalgam/ucm171117.htm\#1

Usher, P. (1976). Evaluating country food in the Northern Native economy. Arctic, 29(2), 105120. Retrieved from http://www.jstor.org/stable/40509261 
Verdon, R., Brouard, D., Demers, C., Lalumiere, R., Laperle, M., \& Schetagne, R. (1991). Mercury evolution (1978-1988) in fishes of the la grande hydroelectric complex, Quebec, Canada. Water, Air, \& Soil Pollution, 56(1), 405-417. doi:10.1007/BF00342287

Whitelaw, G. S., McCarthy, D. D., \& Tsuji, L. J. S. (2009). The victor diamond mine environmental assessment process: A critical first nation perspective. Impact Assessment and Project Appraisal, 27(3), 205-215. doi:10.3152/146155109X465931

Wolfe, M. F., Schwarzbach, S., \& Sulaiman, R. A. (1998). Effects of mercury on wildlife: A comprehensive review. Environmental Toxicology and Chemistry, 17(2), 146. doi:10.1897/1551-5028(1998)017<0146:EOMOWA>2.3.CO;2

Wong, H. C. G. (2017). Mercury poisoning in the grassy narrows first nation: History not completed. CMAJ: Canadian Medical Association Journal, 189(22), E784. doi:10.1503/cmaj.733011

World Health Organization (WHO) \& United Nations Environment Programme (UNEP) DTIE Chemicals Branch. (2008). Guidance for Identifying Populations at Risk from Mercury Exposure. Retrieved from http://www.who.int/foodsafety/publications/chem/mercuryexposure.pdf

Yasutake, A., \& Hirayama, K. (2001). Evaluation of methylmercury biotransformation using rat liver slices. Archives of Toxicology, 75(7), 400-406. doi:10.1007/s002040100256

Zamani-Ahmadmahmoodi, R., Bakhtiari, A. R., \& Rodríguez Martín, J. A. (2014). Spatial relations of mercury contents in pike (Esox lucius) and sediments concentration of the Anzali wetland, along the Southern shores of the Caspian Sea, Iran. Marine Pollution Bulletin, 84(1-2), 97-103. doi:10.1016/j.marpolbul.2014.05.030 